\title{
Vertical Distribution of Pelagic Cephalopods
}

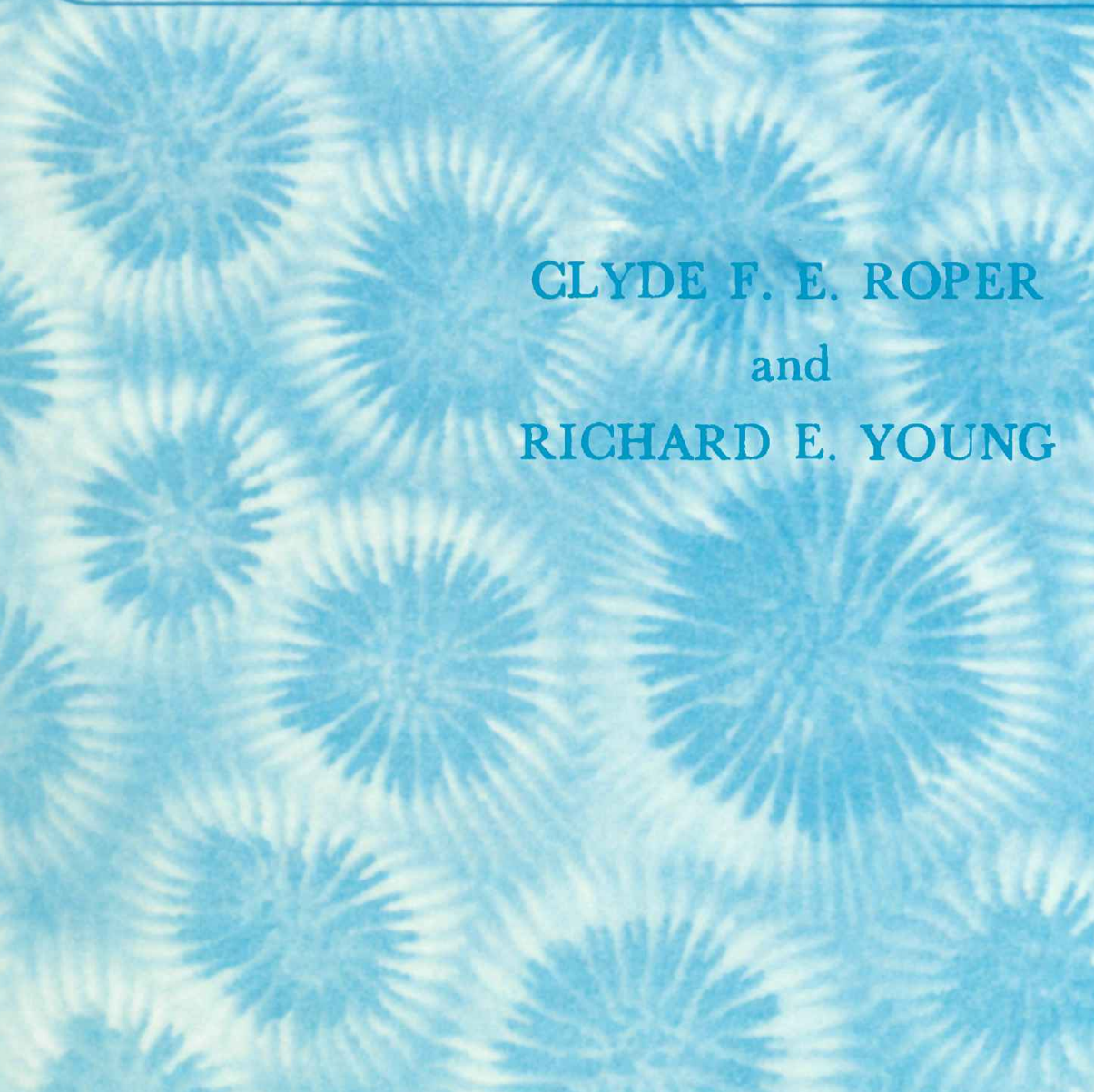




\section{SERIAL PUBLICATIONS OF THE SMITHSONIAN INSTITUTION}

The emphasis upon publications as a means of diffusing knowledge was expressed by the first Secretary of the Smithsonian Institution. In his formal plan for the Institution, Joseph Henry articulated a program that included the following statement: "It is proposed to publish a series of reports, giving an account of the new discoveries in science, and of the changes made from year to year in all branches of knowledge." This keynote of basic research has been adhered to over the years in the issuance of thousands of titles in serial publications under the Smithsonian imprint, commencing with Smithsonian Contributions to Knowledge in 1848 and continuing with the following active series:

$$
\begin{aligned}
& \text { Smithsonian Annals of Flight } \\
& \text { Smithsonian Contributions to Anthropology } \\
& \text { Smithsonian Contributions to Astrophysics } \\
& \text { Smithsonian Contributions to Botany } \\
& \text { Smithsonian Contributions to the Earth Sciences } \\
& \text { Smithsonian Contributions to Paleobiology } \\
& \text { Smithsonian Contributions to Zoology } \\
& \text { Smithsonian Studies in History and Technology }
\end{aligned}
$$

In these series, the Institution publishes original articles and monographs dealing with the research and collections of its several museums and offices and of professional colleagues at other institutions of learning. These papers report newly acquired facts, synoptic interpretations of data, or original theory in specialized fields. These publications are distributed by mailing lists to libraries, laboratories, and other interested institutions and specialists throughout the world. Individual copies may be obtained from the Smithsonian Institution Press as long as stocks are available.

\section{S. Dillon Ripley \\ Secretary \\ Smithsonian Institution}




\title{
Vertical Distribution of Pelagic Cephalopds
}

\author{
Clyde F. E. Roper \\ and Richard E. Young
}

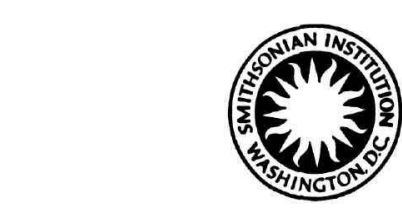

SMITHSONIAN INSTITUTION PRESS

City of Washington

1975 


\section{A B S T R A C T}

Roper, Clyde F. E., and Richard E. Young. Vertical Distribution of Pelagic Cephalopods. Smithsonian Contributions to Zoology, number 209, 51 pages, 31 figures, 1975.-The vertical distributions of pelagic cephalopods are analyzed, based primarily on studies undertaken in the waters off California, Bermuda, and Hawaii. Much of the information is derived from midwater trawl nets equipped with closing apparatus. Each family that contains pelagic or quasipelagic species is discussed; selected records from the literature are included where necessary.

A wide variety of patterns of vertical distribution exists among pelagic cephalopods; patterns may be associated with stage of maturity, diel rhythms, or seasonal behavior. The study revealed that several basic types of vertical distributional patterns occur: near-surface dwellers, first order diel vertical migrators, second order diel vertical migrators, diel vertical shifters, diel vertical spreaders, nonmigrators, vertical wanderers, species associated with the ocean bottom, species exhibiting ontogenetic descent.

Official pUblication DATE is handstamped in a limited number of initial copies and is recorded in the Institution's annual report, Smithsonian Year. SI Press NUmber 5389. Series Cover Design: The coral Montastrea cavernosa (Linnaeus).

Library of Congress Cataloging in Publication Data

Roper, Clyde F. E. 1937-

Vertical distribution of pelagic Cephalopods.

(Smithsonian contributions to 20ology; no. 209)

Bibliography: p.

Includes index.

1. Cephalopoda-North Pacific Ocean. 2. Cephalopoda-Bermuda Islands. I. Young, Richard E., joint author. II. Title. III. Series: Smithsonian Institution. Smithsonian contributions to zoology; no. 209.

QL1.S54 no. 209 [QL430.2] 591'.08s [594'.5'092] 75-6936 


\section{Contents}

\begin{tabular}{|c|c|}
\hline \\
\hline \multicolumn{2}{|l|}{ 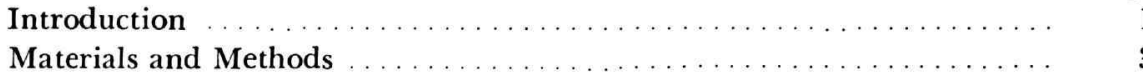 } \\
\hline California Study $\ldots \ldots \ldots \ldots \ldots \ldots \ldots \ldots \ldots$ & \\
\hline 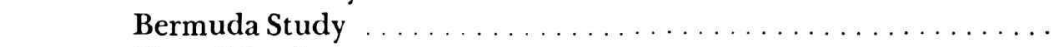 & \\
\hline 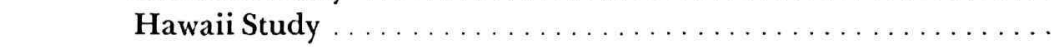 & \\
\hline$\ldots \ldots \ldots \ldots \ldots \ldots \ldots \ldots \ldots \ldots \ldots \ldots \ldots$ & \\
\hline Nautilidae & \\
\hline$\ldots \ldots \ldots \ldots \ldots \ldots \ldots \ldots \ldots \ldots \ldots \ldots \ldots \ldots \ldots$ & \\
\hline . $\ldots \ldots \ldots \ldots \ldots \ldots \ldots$ & \\
\hline (. & \\
\hline . & \\
\hline Sepiadariidae, Sepiolidae, Idiosepiidae & \\
\hline Order Teuthoidea & \\
\hline 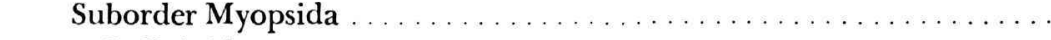 & \\
\hline (2.2. & \\
\hline 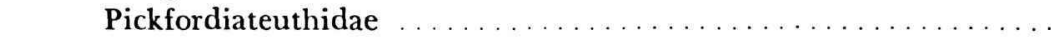 & \\
\hline (2, & \\
\hline Lycoteuthidae & \\
\hline Enoploteuthidae & \\
\hline Ommastrephidae & \\
\hline 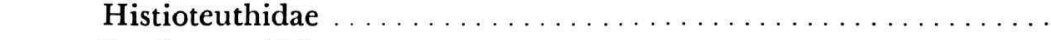 & \\
\hline 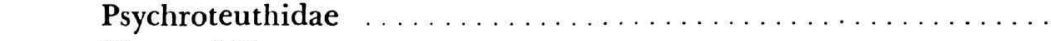 & \\
\hline 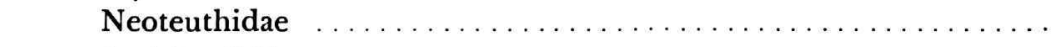 & \\
\hline 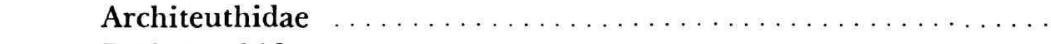 & \\
\hline 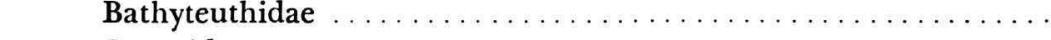 & \\
\hline$\ldots \ldots \ldots \ldots \ldots \ldots \ldots \ldots \ldots$ & \\
\hline$\ldots \ldots \ldots \ldots \ldots \ldots \ldots \ldots \ldots$ & \\
\hline$\ldots \ldots \ldots \ldots \ldots \ldots \ldots \ldots \ldots \ldots \ldots \ldots \ldots$ & \\
\hline Thysanoteuthidae & \\
\hline$\ldots \ldots \ldots \ldots \ldots \ldots \ldots \ldots \ldots$ & \\
\hline Ctenopterygidae & \\
\hline Brachioteuthidae & \\
\hline Lepidoteuthidae & \\
\hline Joubiniteuthidae $\ldots \ldots \ldots \ldots \ldots \ldots \ldots \ldots \ldots$ & \\
\hline Chiroteuthidae & \\
\hline Mastigoteuthidae & \\
\hline Promachoteuthidae .... & \\
\hline Batoteuthidae & \\
\hline Grimalditeuthidae & \\
\hline & \\
\hline
\end{tabular}




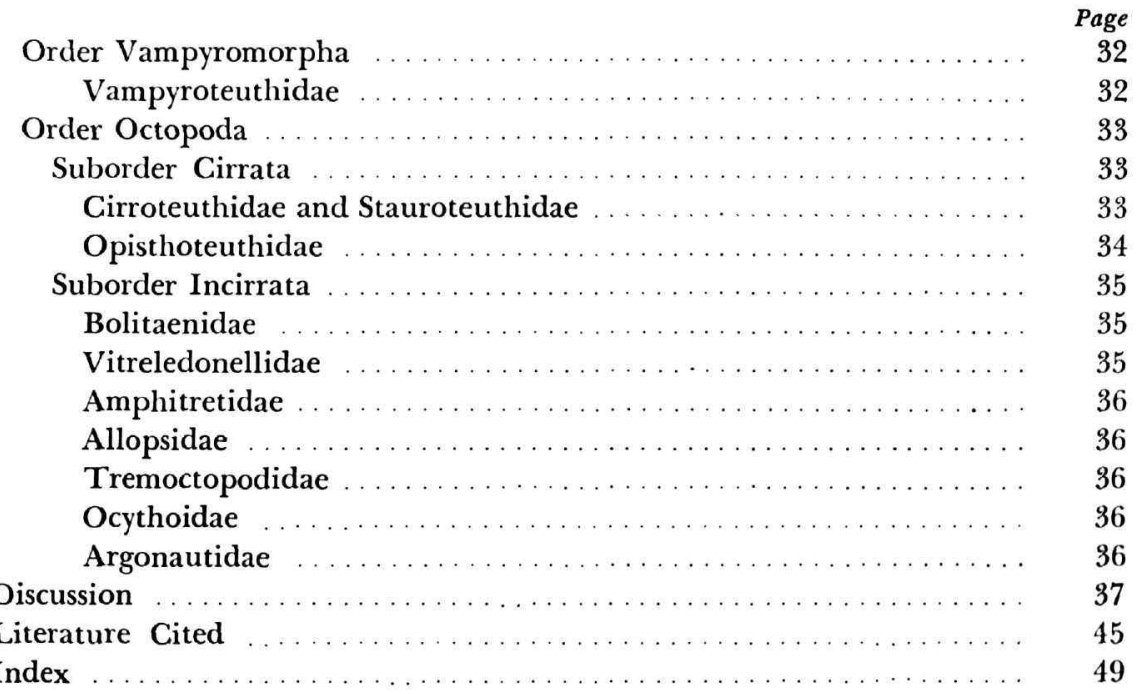




\title{
Vertical Distribution of Pelagic Cephalopds
}

\author{
Clyde F. E. Roper and Richard E. Young
}

\section{Introduction}

Information concerning the vertical distribution of pelagic cephalopods is relatively sparse. Several factors are primarily responsible: (1) Oceanic cephalopods are often large, fast-swimming animals that are able to avoid being captured by conventional sampling gear. (2) Until recently, most specimens were taken in open nets that, in addition to the desired sampling depth, sample the entire water column during setting and retrieval; as a result the true depth of capture is difficult to define precisely. (3) In many groups only larvae and juveniles are captured and adults are rare or unknown. (4) Most sampling has been conducted along geographical transects where a given locality is generally sampled only once, at one time of day and at one season of the year. Compounding these sampling problems are the complexities of the distributional patterns of the cephalopods.

To understand the vertical distributions of cephalopods (as indeed of many oceanic organisms) a knowledge is required of more than merely the bathymetric range, with carefully defined upper and lower limits, over which specimens of a species are known to occur. Often the bathymetric range will extend over a great vertical distance, but the vast majority of a population will occupy only a restricted depth zone. In addition, larvae of a species may inhabit one or more depth

Clyde F. E. Roper, Department of Invertebrate Zoology, Na. tional Museum of Natural History, Smithsonian Institution, Washington, D.C. 20560. Richard E. Young, Department of Oceanography, University of Hawaii, Honolulu, Hawaii 96822. zones that are uninhabited by adults. Therefore, because distributional patterns often differ markedly between growth stages, it is necessary to separate and distinguish between depth records of larval and juvenile-adult populations. Seasonal or daily differences in depth distributions also may occur; for example, some species migrate to nearshore waters in the summer to feed and/or spawn, then migrate into deeper, offshore waters during winter; many species in the day inhabit depths that differ from their nighttime depths. Because of these factors, it is extremely difficult to draw conclusions from most of the literature.

A factor that has led to considerable confusion in the literature is the inability of many workers to recognize the phenomenon of diel vertical migration in which animals ascend toward the surface zone at night and descend to deeper water during the day. Although vertical migrations are well documented in several groups of pelagic animals, evidence of this phenomenon in cephalopods has been inconclusive until recently. The first indication of vertical movements of cephalopods was given in 1841 by d'Orbigny who noted that cephalopods occurred at the surface at night but were absent during the day (vide G. L. Voss, 1967:511). Similar observations have been recorded since that time. For instance, Sasaki (1914:92) stated that Watasenia scintillans comes to the surface at night, where it may be captured by fishermen, and disappears to greater depths during the day. More recently Pearcy (1965) presented trawling data to suggest that some oceanic species show greater frequencies of occurrence in the surface layer 
(0-200 m) during night than during the day, while in the layer of $0-500 \mathrm{~m}$ abundance of these species is greater during the day than during the night. Clarke (1969) compared day-night captures using several different types of sampling gear, among them a closing-net, during the sond cruises in the eastern tropical Atlantic. His results indicate more clearly the existence of vertical migration.

Our studies presented here confirm the occurrence of vertical migration in cephalopods and indicate that this phenomenon is widespread in oceanic squid. These conclusions have relied most heavily on sampling programs conducted in three different oceanic regions of the world. The first study was conducted off southern California by the University of Southern California and involved approximately 900 hours of sampling using open midwater trawls. The second study, known as the Ocean Acre Program, was conducted off Bermuda by the Smithsonian Institution in cooperation with the University of Rhode Island and the U.S. Navy. This study was based upon the use of closing midwater trawls. Projects off Hawaii using closing trawls and open trawls yielded additional information.

This paper reviews the vertical distribution of cephalopods and relies heavily on information derived from the above programs. Much of our data is based on the capture of juvenile specimens. In most species examined, however, juveniles appear to exhibit the same distributional patterns as the adults. Therefore, in most cases, this data can be considered representative of the species.

The larvae of most species of pelagic cephalopods occur in the near-surface waters both during the day and at night and as such do not demonstrate the same distributional patterns as their juvenile and adult forms. In order to determine the distributions of juveniles and adults, therefore, the larvae for each species must be eliminated from the calculations. All specimens that were equal in size (mantle length) to, or smaller than, the largest "larva" captured in near-surface waters during the daytime (indicative of nonmigratory behavior) were eliminated from the calculations.

We have attempted to include pertinent information from the literature. Our treatment of the literature, however, has not been exhaustive because of the problems discussed above, as well as of the danger of interpreting data based on records about which we have no knowledge of the circumstances related to the capture.

The vertical distribution of cephalopods is surveyed by discussing representative species in each family. Knowledge is insufficient to allow a presentation based upon recognized distributional patterns or vertical faunal zones in the open ocean. The systematic approach allows us to present data wherever they exist without having to force them into distributional concepts. Hopefully, within the next few years it will be possible to discuss vertical distribution of cephalopods in relation to the physical and biological parameters of the pelagic environment.

In addition to these primary sources listed above we have utilized data from: (1) a closing-net program in the Mediterranean (Roper, 1974); (2) open midwater trawl sampling of the Antarctic Research Program; (3) bottom trawl surveys in the tropical western Atlantic (National Marine Fisheries Service); (4) a survey with a large, open Engel trawl (WALTHER HERWIG); and (5) our collections from various other areas.

The Ocean Acre and Hawaii data presented here are partial results of continuing programs. The data represent some of the information that was accumulated through January 1972.

For representative illustrations of the various groups of pelagic squid discussed in the following report, the reader may consult Roper, Young, and Voss (1969).

The vertical distributional data are summarized in Figures 24-31. As the graph generalizes data, it should be used in conjunction with the text. The distributions are represented by bars, and only reference to the text will indicate the number of data points available and consequently the reliability of the suggested distributions. Not all species mentioned in the text are included in the graph. The families included in the graph are not necessarily in the same order as in the text.

The following symbols are used in Figures 24-31. Solid bar: distribution of animals not associated with bottom, based primarily on midwater tows. Bars represent centers of distribution where the vast majority of the population occurs. Hachured bar: distribution of animals associated with bottom, based primarily on bottom trawls. Dotted bar: presumed zone of distribution based on limited data. Horizontal dotted line: distribu- 
tional boundary uncertain. Horizontal dashed line: single open-net record. Solid vertical line (or narrow hachured bar): total distributional range occupied by very small portion of population. Dashed vertical line: few data points scattered over broad range of depths; resolution of actual distribution not possible.

Plots for most species show distributions for day (D) and night (N). Where data indicate no daynight differences, they are combined. Since a few species show seasonal changes, their summerwinter (S-W) distributions are plotted. Data for ontogenetic differences in distribution are also plotted where available. " $\mathrm{S} \rightarrow$ " indicates increasing size of non-adult specimens.

Acknowledgments.-We are most grateful to the many individuals and institutions whose aid has made the completion of this study possible through physical and financial support or by supplying data:

University of Southern California Deep-Sea Biology Program; especially J. Garth, J. Lavenberg, M. Murillo, J. McGinnis, and D. Robins; students who participated in cruises of Velero $I V$; National Science Foundation Grant Numbers G-10691 and G-23467.

The Ocean Acre and Mediterranean Biological Studies Programs of the Smithsonian Institution (U.S. Navy Contract Numbers: N00140-72-C-0315 and N00014-67-A-0399-0007); R. Gatton, M. Sweeney, R. Goodyear, R. Gibbs, Jr., D. Brown and all participants in the numerous cruises.

The University of Hawaii deep sea biology projects; T. Clarke, R. Grigg, and students who participated in "Teuthis" cruises, especially J. Walters, S. Amsbury, and F. Riggs; National Science Foundation Grant Numbers GB-20933 (Young); GB-23931 (Clarke).

C. C. Lu, Marine Sciences Research Laboratory, Memorial University of Newfoundland; G. L. Voss, E. McSweeny, U.S. Antarctic Research Program Grant, Rosenstiel School of Marine and Atmospheric Sciences, University of Miami; P. Rancurel, orstom, New Caledonia; A. Cohen, Student Research Associate, Smithsonian Institution; L. Burgess, National Marine Fisheries Service Biological Laboratory, Hawaii; $H$. Bullis and associates, National Marine Fisheries Service Exploratory Laboratory, Pascagoula; G. Krefft and associates, WALTER HERWig, Institut für Seefischeri,
Hamburg; A. G. Smith, R. R. Talmadge, California Academy of Sciences.

K. Lamb and M. Sweeney, Division of Mollusks, National Museum of Natural History, Smithsonian Institution, kindly checked the manuscript for consistency and accuracy of numbers.

The manuscript has been reviewed by $\mathbf{M}$. $\mathbf{R}$. Clarke, Marine Biological Laboratory, Plymouth; K. Mangold, Laboratoire Arago, Banyuls-sur-Mer; T. Okutani, Tokai Regional Fisheries Research Laboratory, Tokyo; G. L. Voss, University of Miami. We sincerely appreciate their comments.

\section{Materials and Methods}

\section{California Study}

Material from California was collected by the University of Southern California over a six-year period from 1960 to 1966. During the program, 445 midwater tows were made with an open Isaacs-Kidd midwater trawl representing over 900 hours of "fishing" at depths from the surface to about $1200 \mathrm{~m}$ (Figure 1). The program yielded over 5000 specimens of pelagic cephalopods. The systematic study of these cephalopods, including the descriptions of a number of new species, was published by Young (1972a).

The reconstruction of the vertical distribution of the species integrates catches over the entire sampling period. Probably, at any given time the vertical extent of these distributions is considerably less than shown. A correction factor that compensates for unequal trawling time at each depth interval has been added to the charts of vertical distribution (white bars). The correction factor represents the catch that would be expected if all depth intervals were sampled as intensively as the most heavily sampled depth. The actual catch (black bars) is presented on the same chart as the correction factor. This technique is useful when low numbers of specimens are available. Because of the low numbers, the actual catch is discussed rather than the adjusted catch except in a few cases where the adjusted catch gives a slightly different picture of the vertical distribution.

Trawling times generally varied between two and four hours; deep tows generally spent four hours at depth. Any tow that was in the water at 0600 hours or at 1800 hours is considered a twi- 
light tow. For example, if a deep tow began at 0115 hours and terminated at 0615 hours, it is classified as a twilight tow and is excluded from the day-night analyses.

The depth limit of the sampling program was approximately $1200 \mathrm{~m}$. A number of tows undoubtedly extended below $1200 \mathrm{~m}$; because it is difficult to determine actual fishing depth of the net, all specimens caught in tows below $1200 \mathrm{~m}$ are lumped into the $1100-1200 \mathrm{~m}$ depth zone in the charts. The data are handicapped by occasional lack of precise depth of capture records. In these cases, depth of capture was considered to be one-third of the wire out. This factor was determined by plotting values of wire out against trawl depths that were obtained from a series of trawl hauls with a depth recording instrument present. The localities of trawling stations off southern California are given in Young (1972a).

The oceanographic regime off southern California is unusually complex. The continental borderland, $80-257 \mathrm{~km}$ in width from the shoreline to the continental slope, contains 12 complete basins, ranging from about $500-2100 \mathrm{~m}$ in depth, several troughs, numerous banks and eight islands. At the western edge of the borderland, the continental slope drops steeply to a depth of about $3500 \mathrm{~m}$. The waters over the borderland are derived from the complex intermixing of several water masses. Surface waters are influenced by the southerly flowing California Current that is derived largely from Subarctic waters and modified through mixing with Central waters. Surface waters also are modified by wind-induced upwelling that brings nutrient-rich waters to the surface from a maximum depth of $200-300 \mathrm{~m}$. Below

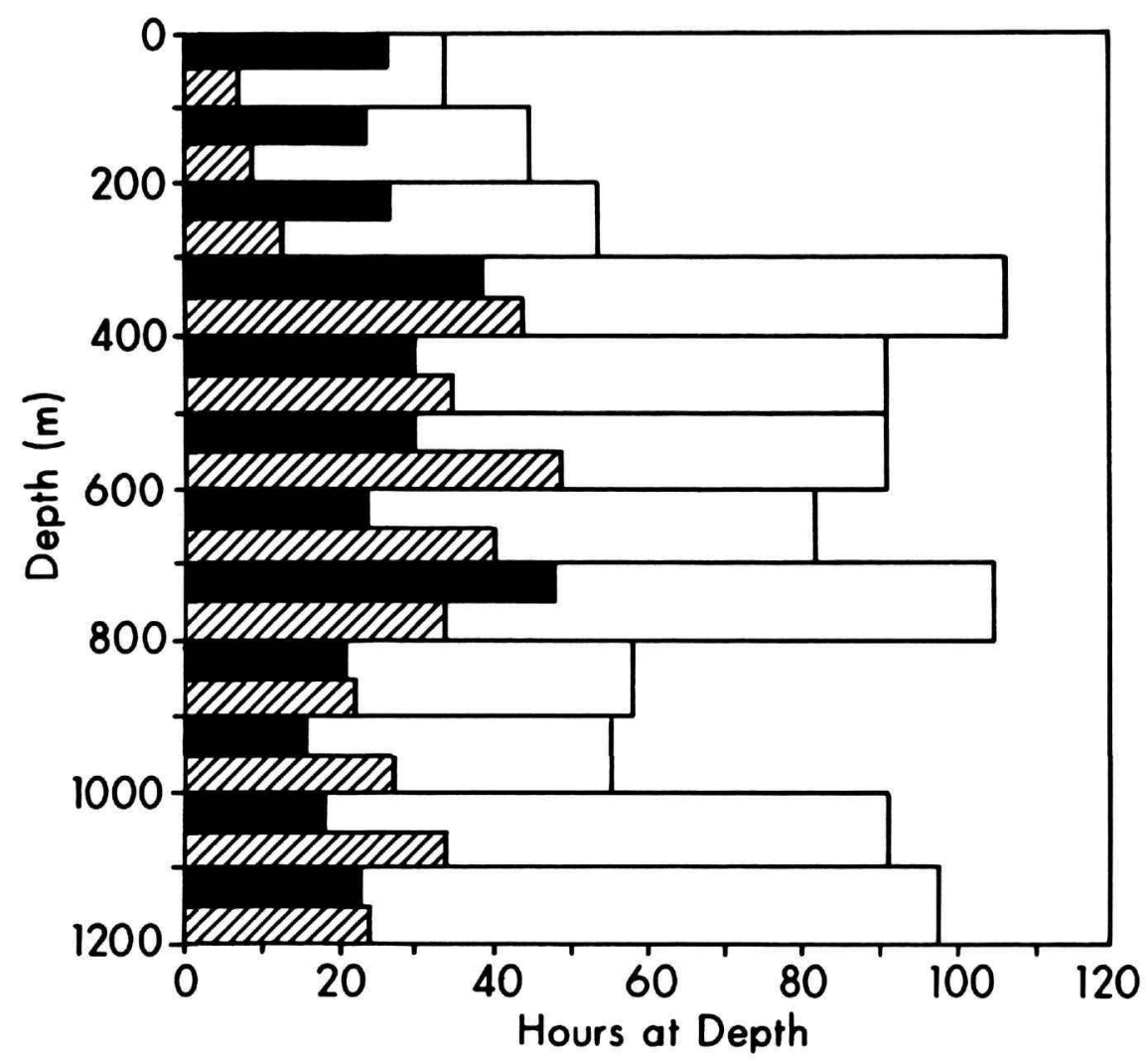

Figure 1.-Hours of trawling at various depths (in $100 \mathrm{~m}$ increments) off southern California. (Black bar $=$ hours of fishing at night; hatchured bar $=$ hours of fishing during the day; white bar $=$ total hours of fishing (day, night, twilight).) 
150-200 m a deep countercurrent of Pacific Equatorial Water flows northward along the coast to at least $40^{\circ} \mathrm{N}$ and progressively mixes with the lower layers of the California Current. (Above discussion based on Reid, Roden, and Wyllie, 1958; Emery, 1960).

The vertical temperature structure of the water shows considerable variation, often in association with large internal waves (Emery, 1956). In general, however, the average surface temperature varies seasonally from about $14^{\circ}$ to $20^{\circ} \mathrm{C}$. The $10^{\circ} \mathrm{C}$ isotherm, which marks the approximate bottom of a strong shallow thermocline, usually lies between $100 \mathrm{~m}$ and $200 \mathrm{~m}$. The $8^{\circ} \mathrm{C}$ isotherm generally fluctuates around the $300 \mathrm{~m}$ level, the $6^{\circ} \mathrm{C}$ isotherm lies between $700 \mathrm{~m}$ and $800 \mathrm{~m}$, and the $4^{\circ} \mathrm{C}$ isotherm occurs at about $1000 \mathrm{~m}$.

Salinity at the surface varies around $33.6 \%$ and gradually increases with depth to about $34.5 \%$ at $1000 \mathrm{~m}$.

Oxygen concentration at the surface is approximately $6.0 \mathrm{ml} / \mathrm{L}$, and between $500 \mathrm{~m}$ and $1000 \mathrm{~m}$ it reaches a minimum that is less than $0.5 \mathrm{ml} / \mathrm{L}$. Emery (1960) gives an oxygen value of $0.2 \mathrm{ml} / \mathrm{L}$ below sill depth in the San Pedro Basin and 0.4 $\mathrm{ml} / \mathrm{L}$ below sill depth in the Catalina Basin. Emery and Hülsemann (1962) found that oxygen does not appear to be a limiting factor on the abundance of the benthic megafauna in the Santa Barbara Basin in concentrations above $0.3 \mathrm{ml} / \mathrm{L}$. Almost no megafauna was present, however, in less than $0.1 \mathrm{ml} / \mathrm{L}$. A rich cephalopod fauna occurs in the oxygen minimum zone; and no correlation is apparent between the patterns of vertical distribution of cephalopods and the oxygen minimum layer.

\section{Bermuda Study}

The cephalopod data utilized here from off Bermuda are part of a study known as the Ocean Acre Program. Details of the long-term program are given in Gibbs and Roper (1970) and Gibbs, Roper, Brown, and Goodyear (1971).

The principal sampling gear was a $3 \mathrm{~m}$ IsaacsKidd midwater trawl (3 m IKMT) equipped with a cod-end closing device. The fourchambered, electronically actuated sampler is described in detail by Aron, Raxter, Noel, and Andrews (1964). The apparatus allows the col- lection of three discrete samples at a precise depth and a fourth sample during retrieval of the net from fishing depth to the surface. The gates that separate the chambers are closed by means of a solenoid-actuated triggering mechanism.

The experimental design for Ocean Acre included a regime of depths and times for seasonal discrete-depth sampling. Twelve standard depths were established for sampling the water column during each cruise; each depth was sampled at least once during full daylight hours and once during the night. Trawls that occurred one and one half hours before and after sunset and sunrise were considered to be twilight tows.

The Ocean Acre study area is located east of Bermuda and encompasses a $1^{\circ}$ square area centered at $32^{\circ} \mathrm{N}, 64^{\circ} \mathrm{W}$. The site has relatively simple oceanographic characteristics, at least in comparison with other deep-water localities in the western Atlantic. The depth of the water in Ocean Acre ranges from about $2000 \mathrm{~m}$ in the northwest corner to $4500 \mathrm{~m}$ in the southwest region. The physical oceanography is summarized here from Gibbs and Roper (1970:120).

The Surface Water Mass occupies the upper $600 \mathrm{~m}$; surface temperatures range from $20^{\circ}$ to $29^{\circ} \mathrm{C}$ and salinity generally is above $36.4 \%$. A seasonal shallow thermocline occurs between $50 \mathrm{~m}$ and $150 \mathrm{~m}$ during April to November, with a peak intensity in August. A temperature reduction of $8^{\circ} \mathrm{C}$ can occur within the thermocline in a vertical distance of $50 \mathrm{~m}$. Below the thermocline temperature and salinity remain nearly uniform $\left(18^{\circ}-\right.$ $19^{\circ} \mathrm{C}$ and $36.2^{\circ} \%$ ) to about $600 \mathrm{~m}$. From about 600-1100 m a permanent deep thermohalocline occurs that is identified as North Atlantic Central Water. Temperature changes from $18^{\circ}$ to $6^{\circ} \mathrm{C}$ and salinity from $36.2-35.0 \%$ over this depth range. Intermediate water is present between $1100 \mathrm{~m}$ and $2000 \mathrm{~m}$ with temperatures of $5.5^{\circ}$ to $4.0^{\circ} \mathrm{C}$ and a salinity of about $35.0 \%$. Characteristic North Atlantic Deep Water, with temperatures below $3.5^{\circ} \mathrm{C}$ and a salinity around $35.0 \%$, occurs below $2000 \mathrm{~m}$. Oxygen levels generally are between 4.5 and $5.5 \mathrm{ml} / \mathrm{L}$ at the surface and decrease until about $700-900 \mathrm{~m}$, where an oxygen minimum layer occurs with concentrations around $3.5 \mathrm{ml} / \mathrm{L}$. Below $700-900 \mathrm{~m}$, oxygen concentrations again increase to greater than $6.0 \mathrm{ml} / \mathrm{L}$ at $2000-3000 \mathrm{~m}$. Characteristics of the sound scattering layer are 
difficult to define. With a $12 \mathrm{kHz}$ sound source, a weak and variable scattering layer usually is present at 0-150 m during the day, while a deep, strong layer occurs between $400 \mathrm{~m}$ and $600 \mathrm{~m}$. At night the scattering layer is very prominent between $0 \mathrm{~m}$ and $250 \mathrm{~m}$, and the $400-600 \mathrm{~m}$ layer, though diminished and narrower, is still intact.

\section{Hawail Study}

In Hawaiian waters the area of study lies about seven miles off the leeward side of Oahu where water depth exceeds $2000 \mathrm{~m}$. Sampling gear was a modified $10^{\prime}$ Tucker trawl with an opening-closing system in the mouth that is actuated by acoustic signals from the ship. An open $3 \mathrm{~m}$ Isaacs-Kidd midwater trawl also was used extensively.

Most oceanographic features off Hawaii are very stable throughout the year. The seasonal range in surface temperature is from $23^{\circ}$ to $26^{\circ} \mathrm{C}$. A weak, shallow thermocline at about $35 \mathrm{~m}$ forms during the spring and summer, while a permanent thermocline extends from about $100 \mathrm{~m}$ to about $400 \mathrm{~m}$ where the temperature is around $8^{\circ} \mathrm{C}$. Temperature at $1000 \mathrm{~m}$ is $4^{\circ} \mathrm{C}$ and decreases to $2^{\circ} \mathrm{C}$ at $2000 \mathrm{~m}$. Surface salinity is between $34.7 \%$ and $35.2 \%$; between $400 \mathrm{~m}$ and $500 \mathrm{~m}$ a strong salinity minimum occurs (less than $34.2 \%$ ), which marks the core of North Pacific Intermediate Water. The very homogeneous Pacific Deep Water lies below about $1500 \mathrm{~m}$. Dissolved oxygen falls to a minimum of about $0.7-1.0 \mathrm{ml} / \mathrm{L}$ at about $700 \mathrm{~m}$. (Above discussion based on Gordon, 1970).

\section{Subclass NAUTILOIDEA}

\section{NAUTILIDAE}

FIGURE 24: BARS 1, 2

Nautilus occurs in tropical Indo-Pacific waters. Species of the genus apparently are not truly pelagic, as living specimens generally are captured near the ocean bottom. Specimens commonly are caught in bottom traps, and in captivity they spend most of the day at rest on the bottom of the aquarium and swim chiefly at night (Bidder, 1962; Stenzel, 1957). Nautilus macromphalus is caught in shallow water at night and occasionally may be taken at the surface by fishermen (Rancurel, pers. comm.). The maximum depth to which any species of Nautilus can descend is uncertain. Denton and Gilpin-Brown (1966:755) estimated that the shell of $N$. macromphalus is sufficiently strong to withstand hydrostatic pressures to a depth of 600 $\mathrm{m}$, while Collins and Minton (1967) showed experimentally that the siphuncular tube can withstand pressures equivalent to $480 \mathrm{~m}$. In New Caledonia $N$. macromphalus occurs at least as deep as $200 \mathrm{~m}$ during the day (Rancurel, pers. comm.). Bidder (pers. comm.) captured a female specimen of $N$. pompilius in a trap at $200 \mathrm{~m}$ in the Bay of Rabaul, New Britain, off Vulcan Island. The trap had been set on sandy bottom for only a few hours during the daytime. One specimen of $N$. pompilius was obtained by the Challenger off Matuku Island, Fiji, in a dredge haul to $576 \mathrm{~m}$ (Moseley, 1879: 256), but Bidder (pers. comm.) feels it may have been caught at a shallower depth as the dredge fished up the slope.

\section{Subclass COLEOIDEA}

\section{Order SEPIOIDEA}

\section{SPIRULIDAE}

FIGURE 24: BAR 3

Bruun (1943:23) investigated the vertical distribution of Spirula spirula and concluded that it occurs between $200 \mathrm{~m}$ and $1750 \mathrm{~m}$, except in areas of upwelling where it is found as shallow as $100 \mathrm{~m}$. Bruun (1955) re-examined the distribution of Spirula and maintained that the upper limit as previously determined was correct. He revised his original estimate of the lower limit of occurrence of Spirula, and, based on inconclusive data, implied that this limit probably coincides with the $10^{\circ} \mathrm{C}$ isotherm. In attempting to correlate the $10^{\circ} \mathrm{C}$ isotherm with geographical distribution Bruun stated (1955:68): "It is obvious that all Spirula fall within the regions where the temperature is about $10^{\circ} \mathrm{C}$ or higher at a depth of $400 \mathrm{~m}$." (Actually, this is not at all obvious from the chart). His use of the term "regions" refers to geographical regions, but this has been interpreted as vertical region, which led to the misconception that the lower limit of the vertical distribution of Spirula is $400 \mathrm{~m} \mathrm{(G.} \mathrm{L.} \mathrm{Voss,} \mathrm{1967:516).} \mathrm{We} \mathrm{are} \mathrm{left} \mathrm{with}$ 
Bruun's suggestion that the lower limit is the $10^{\circ} \mathrm{C}$ isotherm or the lower boundary of what Bruun termed the thermosphere; this would correspond to a maximum depth in some areas of about $700 \mathrm{~m}$ (Bruun, 1957:641).

Bruun (1943:10) found that pressures of 40-65 atmospheres (about 400-650 m) imploded Spirula shells collected from the beach; he suggested that shells in the living animal might be stronger. Denton and Gilpin-Brown (1971:367) found experimentally that the chambered shells of Spirula in the intact animal are able to withstand pressures equivalent to those occurring at around $1700 \mathrm{~m}$.

Recently Clarke (1969) presented data on the vertical distribution of Spirula based on 70 specimens captured near the southern end of the Canary Islands. Using an Isaacs-Kidd midwater trawl equipped with a Foxton closing device, he showed that Spirula undergoes vertical migration. Clarke found the daytime center of distribution to be at 500-700 m, while at night Spirula ascended to 100-300 m. No specimens were taken shallower than $500 \mathrm{~m}$ during the day, but a few were captured well below the center of distribution to depths of $950 \mathrm{~m}$.

\section{SEPIIDAE}

The sepiids are quasipelagic, generally burying themselves in the bottom during the day and emerging at night to feed. Therefore, they are beyond the scope of this report.

\section{SEPIADARIIDAE, SEPIOLIDAE, IDIOSEPIIDAE}

Among these three families, only certain members of the Sepiolidae are wholly pelagic. Within the Sepiolidae, the Rossiniae and the Sepiolinae are benthic or quasipelagic and spend much of the time buried in the substrate (Naef, 1923).

The remaining subfamily in the Sepiolidae, the Heteroteuthinae (Figure 24:4-7) generally possess silvery bands along the lateral surfaces of the mantle and head. This feature in other cephalopod groups is usually associated with a pelagic habit in the zone of light penetration. Little information exists, however, on the actual vertical range of members of the subfamily.
The vertical distribution of the best-known species, Heteroteuthis dispar, was studied by Degner (1925) in the Mediterranean Sea. Captures were made in open nets and depths recorded only as meters of wire out. We have considered the depth of capture to be one-half the length of wire out; this method gives a probable maximum fishing depth (see discussion in Bruun, 1943:21). Degner, reporting on 124 specimens, found that 5.6 percent of the specimens were captured above $35 \mathrm{~m}, 72.5$ percent were captured between 35-150 $\mathrm{m}$, and 21.8 percent were captured below $150 \mathrm{~m}$. Unfortunately, the sizes of individual specimens were not reported. They ranged from at least 2-12 $\mathrm{mm}$ ML (mantle length), with specimens from about 2-4 $\mathrm{mm} \mathrm{ML}$ apparently predominating. Most specimens were captured over deep water. Some of the specimens captured below $150 \mathrm{~m}$ are very likely contaminants that were caught while the open nets passed through the populated layer.

Clarke (1969:970) has also presented evidence based on closing nets for a shallow living habitat in $H$. dispar. He found that specimens of this species with mantle lengths greater than $2 \mathrm{~mm} \mathrm{(24}$ specimens) were captured during daytime at depths of 110-255 m and at night near the surface $(0-70 \mathrm{~m})$ to $265 \mathrm{~m}$.

Our closing net captures from the Mediterranean also indicate the shallow occurrence of $H$. dispar, although several specimens were captured as deep as $400-500 \mathrm{~m}$ during the day. Four specimens were captured between 150 and $250 \mathrm{~m}$ and 10 specimens were captured between 400 and 500 $m$ during the day. At night 16 specimens were taken between 50 and $300 \mathrm{~m}$ (size range of all specimens: 3-25 mm ML).

We have scattered observations on mature or nearly mature specimens in two of the remaining four recognized genera in the Heteroteuthinae (Nectoteuthis, Iridioteuthis, Stoloteuthis, Sepiolina). We have recorded 12 specimens of Stoloteuthis leucoptera taken in five otter (bottom) trawls that fished at the following depths (in meters): $145,156,161,172,188$; one specimen was taken at night in an open midwater trawl that fished at $350-0 \mathrm{~m}$. Six specimens of Stoloteuthis maoria were captured during daytime in two otter trawls that fished on the bottom at $420-440 \mathrm{~m}$ and four specimens were taken at night in an open midwater trawl that fished from 53-0 $\mathrm{m}$ over water 
$500-575 \mathrm{~m}$ in depth. Three specimens of Nectoteuthis pourtalesi were taken in two bottom trawls that fished at depths of 394 and $385 \mathrm{~m}$.

Although it is apparent from the above records that Heteroteuthis occurs in the upper few hundred meters during both day and night, the full extent of its range is still uncertain. Examination of the photosensitive vesicles of a species of Heteroteuthis ( $H$. hawaiiensis) has revealed a small group of vesicles similar in size to those of the shallow living Loligo vulgaris. This further suggests to us that Heteroteuthis is a shallow living animal. The captures of $H$. dispar from $400-500 \mathrm{~m}$ in the Mediterranean, however, are difficult to interpret and remain unexplained until more extensive data are obtained.

Although Heteroteuthis probably is pelagic throughout its life cycle, the habitats of the species in the remaining genera are much less clear. The rather meager data indicate that at least some of these species occur at rather shallow depths. The preponderance of specimens taken in bottom trawls compared to midwater captures suggests that these species spend considerable time on or near the bottom.

\section{Order TEUTHOIDEA}

\section{Suborder MYOPSIDA}

\section{LOLIGINIDAE}

Figure 24: BARS 8-14

Members of the family are primarily neritic; i.e., generally they are not found over deep water and apparently are restricted to waters of the coastal margins and continental shelves (Summers, 1969). Although all of the approximately 50 known species of loliginids have been recorded from shallow water, details of vertical distributions are known for very few species. The records of captures are based primarily on bottom trawls. Summers (1969) records winter captures of Loligo pealeii from Georges Bank to Cape Hatteras in depths of 28-366 $\mathrm{m}$ with the highest concentration at $110-183 \mathrm{~m}$; in summer the species migrates inshore to spawn and occurs at depths as shallow as a few meters.
Differences in captures during the day and at night in winter suggest that the squid disperse vertically into the water column at night. In late winter $L$. pealeii is concentrated in the canyons of the slope at 100-200 $\mathrm{m}$ where water temperatures remain at $9^{\circ}$ to $12^{\circ} \mathrm{C}$ (Vovk, 1969); with warming waters in spring the concentrations move northward and inshore. The northern limit of distribution is about $600 \mathrm{~km}$ further north in summer than in winter (Summers, 1969).

Mangold-Wirz (1963:249) records depth distributions of the following species of loliginids from the Catalane Sea: In $L$. vulgaris the depth at which peak abundance occurs $(40-120 \mathrm{~m})$ varies seasonally, being shallowest in the spring when adults come inshore to spawn. Alloteuthis media exhibits an inshore-offshore migration similar to that of $L$. vulgaris. Total ranges are approximately 20-200 m. Results of exploratory fishing off the northwest African shelf (Porebski, 1970) give an indication of possible diel vertical movement of Loligo vulgaris. Bottom trawls fished from 20-280 $\mathrm{m}$ yielded positive captures (abundance varied with depth and locality) during daylight hours, but after 1900 hours no $L$. vulgaris were captured in the trawls, indicating that the animals either leave the bottom and disperse into midwater at night, or move to depths that were not sampled. In the English Channel waters near Plymouth $L$. forbesi is taken readily in bottom trawls during the day at 13-104 m, but is absent from tows made at night (Holme, 1974:496).

LaRoe (1967:50) found that Loligo (= Doryteuthis) plei in the tropical western Atlantic generally occurs from the surface to $180 \mathrm{~m}$; Sepioteuthis sepioidea, a very shallow living tropical species, is associated with coral reefs and turtle grass, and is recorded from the surface to $21 \mathrm{~m}$. Lolliguncula brevis is recorded by LaRoe (1967: 84) from $85 \mathrm{~m}$ (one capture) to the surface, with the great majority in less than $18 \mathrm{~m}$.

Although many species of loliginids may be seen at the surface at night over shallow depths, the success of capture with bottom trawls suggests that most species live near the bottom during the day. 


\section{PICKFORDIATEUTHIDAE}

FIGURE 24: BAR 15

This monotypic family, containing only Pickfordiateuthis pulchella, has been captured in shallow tropical waters from the surface to $3-4 \mathrm{~m}$ (LaRoe, pers. comm.).

\section{Suborder OEGOPSIDA}

The great majority of truly oceanic species of cephalopods are included in the Oegopsida. The group is very diversified and contains over half of all families and genera of living cephalopods. Members of the Oegopsida inhabit a wide variety of oceanic habitats. Some live at or near the surface; some undergo diel vertical migrations; some are restricted to the depths; some undergo shoreward seasonal migrations, and some are associated in part with the ocean bottom.

\section{LYCOTEUTHIDAE}

FIGURE 25: BAR 1

G. L. Voss (1962:273) suggested that members of the family occupy the zone from $300-600 \mathrm{~m}$. Oregoniateuthis springeri is recorded from a single open net $(367-0 \mathrm{~m})$.

Lycoteuthis diadema is recorded from seven captures of adults in open nets that fished at (in meters): 366 (2 stations), 403, 589, 1500, 2195, 3000, and two captures of larvae at $46 \mathrm{~m}$ and $57 \mathrm{~m}$ (G. L. Voss, 1962:275-277). Lampadioteuthis megaleia is recorded from one adult taken at night in an open net that presumably did not descend below $200 \mathrm{~m}$ (400 $\mathrm{m}$ of wire out) and two larvae (Young, 1964).

Selenoteuthis scintillans was previously known from two records: $46 \mathrm{~m}$ at night in an IKMT and 0-3290 m (G. L. Voss, 1962:294). Some closing net data on $S$. scintillans are available from off Bermuda (9 specimens, 11-32 $\mathrm{mm} \mathrm{ML).} \mathrm{Five} \mathrm{speci-}$ mens were captured from 610-650 $\mathrm{m}$ during the day and four specimens were taken at 90-130 m at night.

Selenoteuthis scintillans apparently undergoes an extensive diel vertical migration. While data on other species are almost completely lacking, we suspect that vertical migratory behavior may be typical of the group.

\section{ENOPLOTEUTHIDAE}

Figures 2-5, 25: Bars 2-15

Some members of the Enoploteuthidae are among the most commonly caught squids in midwater trawls. Three subfamilies are known, and within each, the assemblage of species shows considerable homogeneity in size and appearance. The subfamily Enoploteuthinae consists of four genera: Enoploteuthis, Abralia, Abraliopsis, and Watasenia.

We have data from California, Bermuda, and Hawaii on three species of Abraliopsis.

Nine hundred and thirty specimens of Abraliopsis felis from open nets were examined from California, of which 480 specimens were used in plotting the vertical distribution; the remainder were too small (less than $15 \mathrm{~mm} \mathrm{ML}$ ) or were captured during twilight. During the daytime only two specimens were captured above $300 \mathrm{~m}$; 93 percent of the specimens were captured between 300 and $600 \mathrm{~m}$ with a strong peak between 400 and 500 $\mathrm{m}$ (Figure 2). The specimens listed below $600 \mathrm{~m}$ probably are contaminants. The exact nighttime position of the population is less clear. The specimens (27 percent) located below $500 \mathrm{~m}$ probably are contaminants. Seventy-five percent of the remaining specimens are located in the upper $300 \mathrm{~m}$ and 62 percent in the upper $200 \mathrm{~m}$. It is uncertain how many of the specimens taken between $200 \mathrm{~m}$ and $500 \mathrm{~m}$ are contaminants, so it is difficult to put a lower limit on the major portion of the population at night. The data show that Abraliopsis felis undergoes a diel vertical migration covering an average distance of over $300 \mathrm{~m}$, ascending from a mean daytime depth of $450 \mathrm{~m}$ to a mean nighttime depth of $100 \mathrm{~m}$.

A great disparity exists between the number of specimens captured during the daytime and at night. Perhaps members of this species school during the day and break up into small groups or completely dissociate at night in the shallower water. Trawl data support this suggestion. Trawls that fished at day below $300 \mathrm{~m}$ occasionally caught large numbers of $A$. felis (e.g., 93, 63, 54, 44 specimens) while a maximum of eight specimens was taken in a single trawl that fished above $300 \mathrm{~m}$ at night.

Pearcy (1965) found that $A$. felis (as Abraliopsis sp.) off Oregon shows a greater frequency of 
occurrence in the surface layer (0-200 m) during the night than during the day; while in the layer of $0-500 \mathrm{~m}$, occurrence is greater during the day than during the night. These data suggest a distributional pattern similar to that for the same species off California.

Off Bermuda, closing-net captures of Abraliopsis pfefferi (15-27 mm ML) during the daytime occur at $610-650 \mathrm{~m}$ (three specimens) and at night four specimens larger than $15 \mathrm{~mm}$ ML were captured at 50-100 m. Therefore an extensive vertical migration also is indicated for this species.

Ten specimens of Abraliopsis sp. $\quad(9-20 \mathrm{~mm}$ ML) off Hawaii were captured in closing nets during the day between $500 \mathrm{~m}$ and $600 \mathrm{~m}$. At night 41 specimens (19-20 $\mathrm{mm} \mathrm{ML)} \mathrm{were} \mathrm{taken} \mathrm{in} \mathrm{open}$ nets; nearly 75 percent of these were captured in tows that fished between 50 and $100 \mathrm{~m}$. One specimen (16 mm ML) was taken in a closing net at $60 \mathrm{~m}$.

Information on the other genera in the subfamily is scarce. Berry (1926) recorded Abralia veranyi from Madeira; specimens were observed and captured in Funchal Harbor at night during summer, but were absent during the day. We also have dipnetted $A$. veranyi at night in Bahamian waters. A number of specimens of several species of Abralia also have been taken at or near the surface presumably at night (Clarke, 1966:170). These observations suggest that species of Abralia probably migrate vertically to or near the surface at night and descend during the day.

Off Bermuda Abralia is infrequently caught. Two closing trawl captures were made of $A$. red-

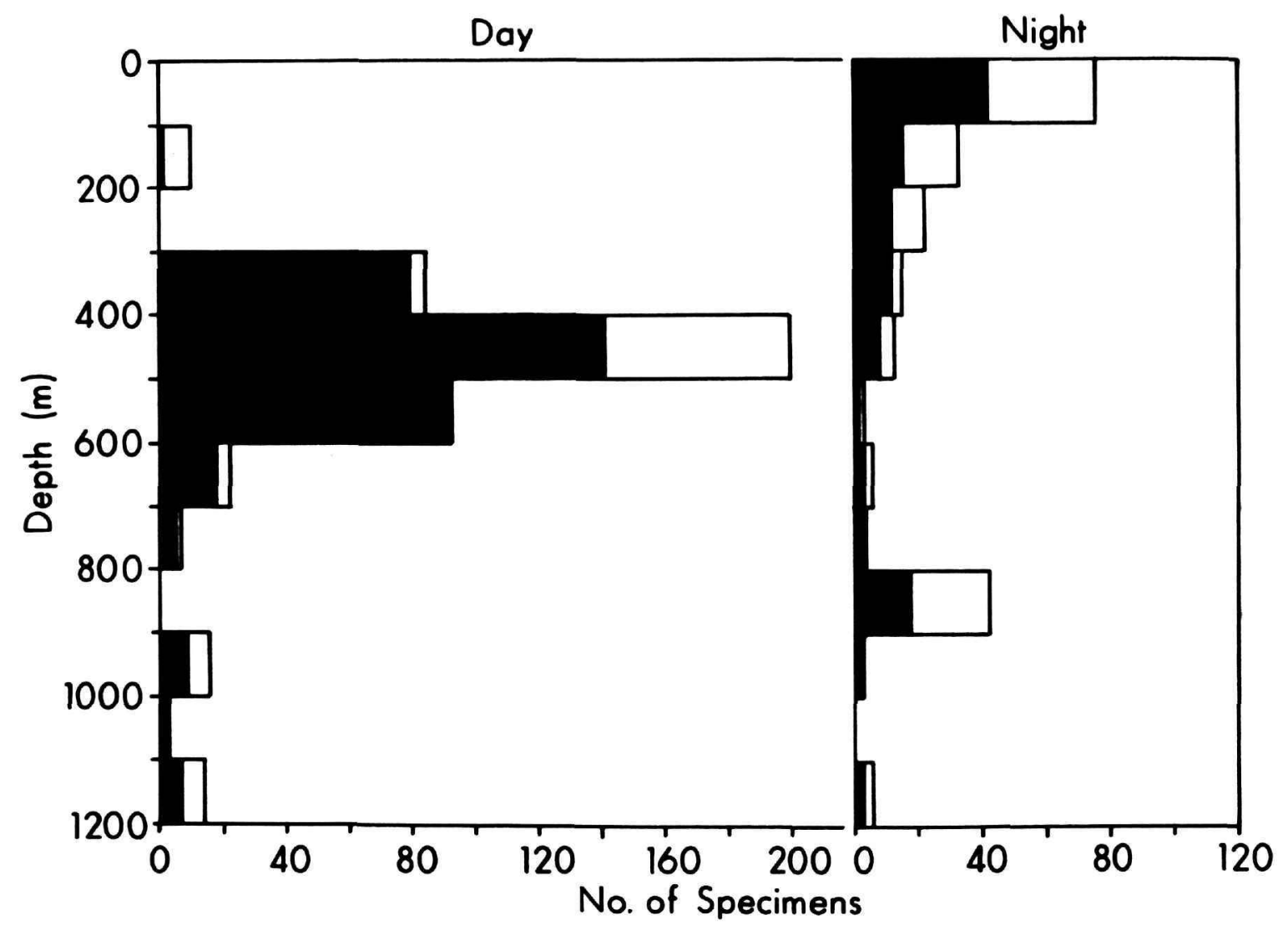

FigUre 2.-Vertical distribution of Abraliopsis felis off southern California. (Black bar = number of specimens captured; white bar = correction factor.) 
fieldi at night at $50 \mathrm{~m}$. Daytime captures are absent in spite of intensive sampling from the surface to $750 \mathrm{~m}$.

Abralia astrosticta from off Hawaii is known from only a few captures. Although small specimens have been taken in midwaters, most large specimens have been taken in bottom trawls ( $\mathbf{L}$. Burgess, National Marine Fisheries Service Laboratory, Honolulu, pers. comm.). One adult (48 mm ML) was taken in a gill net on the ocean bottom at night in $180 \mathrm{~m}$. Extensive pelagic trawling around Hawaii has failed to capture any adults. The meager data suggest that this species may associate with the ocean bottom off oceanic islands.

Off Hawaii three specimens of $A$. trigonura (30-37 $\mathrm{mm} \mathrm{ML}$ ) were captured in a closing net that fished between $460-600 \mathrm{~m}$ during the day. In open nets nine specimens (15-37 mm ML) were taken between 490 and $575 \mathrm{~m}$ during the day and a single specimen, probably a contaminant, was taken from an open net that fished at $775 \mathrm{~m}$. At night, two specimens (22 $\mathrm{mm}$ and $37 \mathrm{~mm} \mathrm{ML}$ ) were captured from 100-0 m.

Sasaki (1914:103) studied the distribution of Watasenia scintillans in Japan and concluded that in the spring and summer it lives deeper than 200 $m$ during the day and in the evening it approaches the shore or shallow sea floor to spawn. This is a spawning migration; whether $W$. scintillans in addition undergoes an oceanic daily vertical migration is as yet unknown to us.

Roper (1966) presented capture data on Enoploteuthis anapsis, which included six juvenile and adult specimens (17-79 $\mathrm{mm} \mathrm{ML)} \mathrm{that} \mathrm{were} \mathrm{cap-}$ tured at night between 0-120 m. One Bermuda specimen ( $15 \mathrm{~mm} \mathrm{ML}$ ) was taken in a closing net at $90 \mathrm{~m}$ at night. Three additional specimens of Enoploteuthis sp. were taken in closing nets at night; two specimens at $90 \mathrm{~m}$ and one at $130 \mathrm{~m}$. No daytime closing-net captures have been made to date.

The Pyroteuthinae contains two genera, Pyroteuthis and Pterygioteuthis. Pyroteuthis margaritifera is one of the most abundant squids taken in the Ocean Acre program off Bermuda; 163 specimens (5-27 mm ML) were captured in closing nets and their distributions are plotted on a timedepth chart (Figure 3). The boxed digits indicate the number of specimens caught at a given time and depth per hour of trawling throughout the

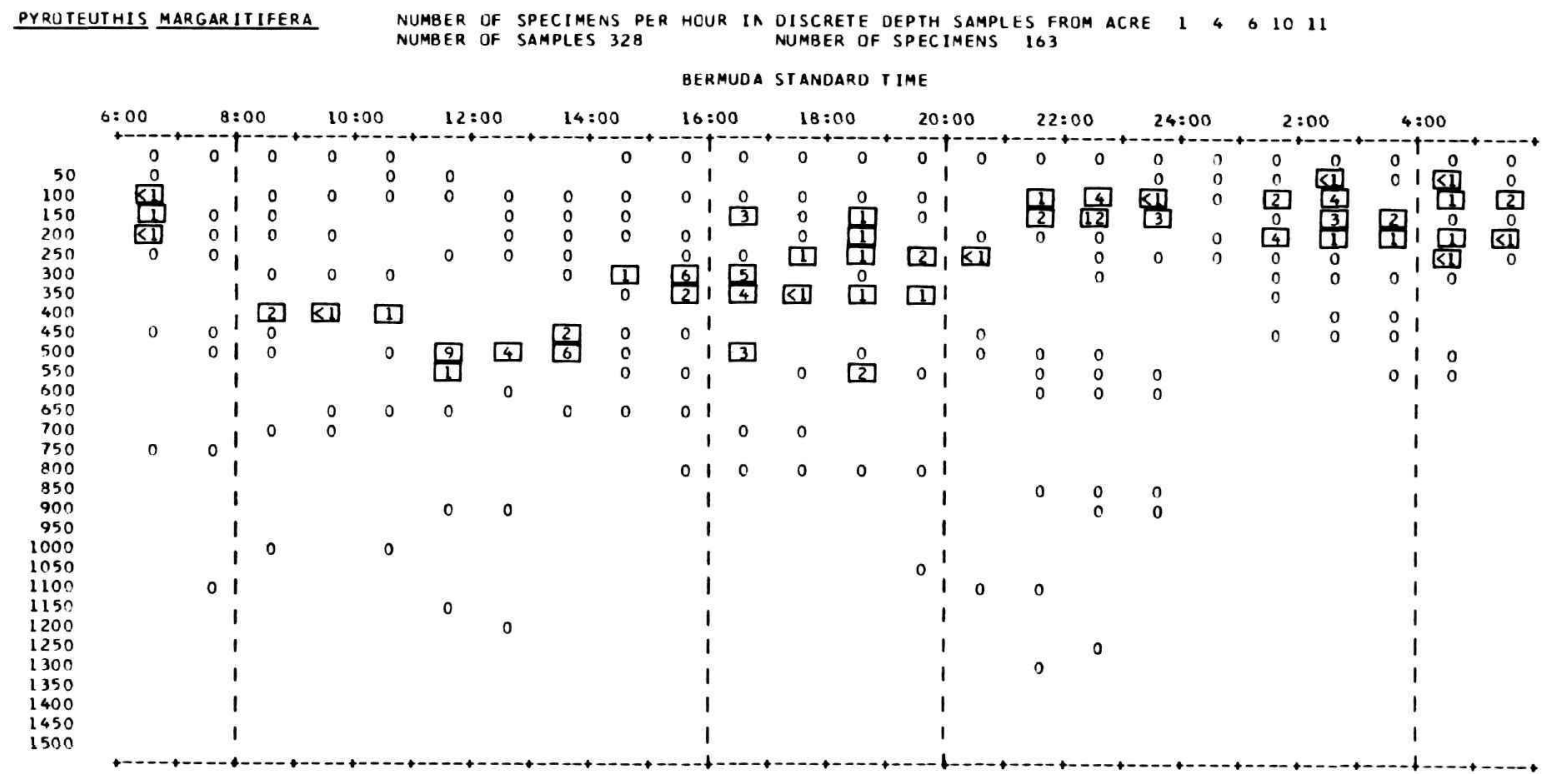

FIGURE 3.-Vertical distribution of Pyroteuthis margaritifera off Bermuda. Time-depth plot of positive and negative captures and sampling effort. (See page 11 for explanation of symbols.) 
24-hour cycle, as well as the time-depth location of samples that caught no specimens of $P$. margaritifera (indicated by a zero); blank spaces represent time-depth loci that were not sampled. During the day over 80 percent of the 43 specimens captured came from $375-500 \mathrm{~m}$. Sixty-two specimens were captured at night from $75-175 \mathrm{~m}$. Pyroteuthis margaritifera, therefore, undergoes a diel vertical migration of about $300-350 \mathrm{~m}$.

During the daytime there is no size stratification with depth. At night a possible size stratification may occur but data are inconclusive. During the day only a single adult was captured while at night three were captured.

In Pterygioteuthis 130 specimens of $P$. gemmata from open nets were available for analysis from California after elimination of "larval" specimens less than $11 \mathrm{~mm}$ ML and twilight captures (Figure 4). Of the 56 daytime captures, 3 percent were taken in the upper $300 \mathrm{~m}$; 56 percent were taken from $300-600 \mathrm{~m}$; 25 percent from $600-900 \mathrm{~m}$; and 16 percent from $900-1200 \mathrm{~m}$. A small peak is present at $700-800 \mathrm{~m}$ as a result of a single trawl which likely captured the specimens during retrieval through the upper layers. The daytime cap-

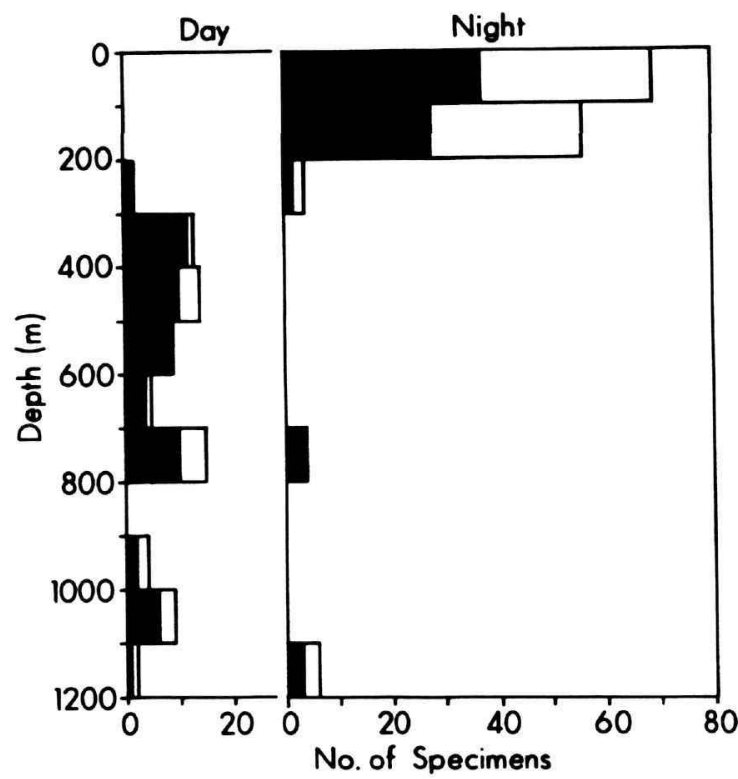

FigUre 4.-Vertical distribution of Pterygioteuthis gemmata off southern California. (Black bar $=$ number of specimens captured; white bar $=$ correction factor.)

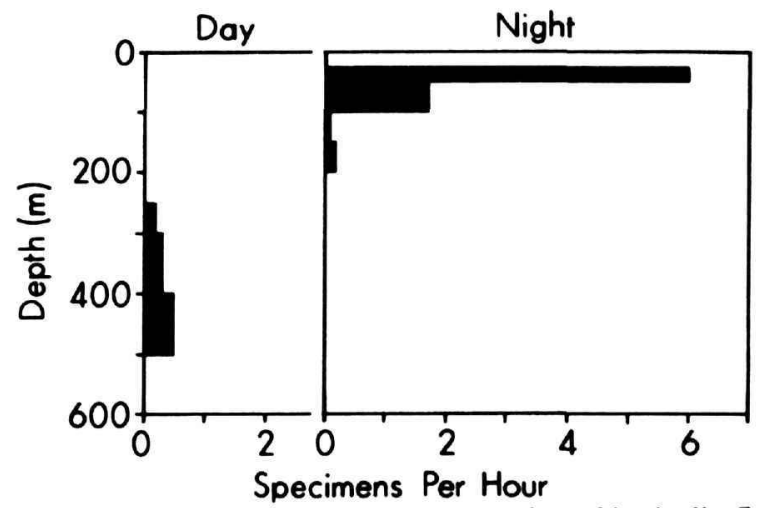

Figure 5.-Vertical distribution of Pterygioteuthis giardi off Bermuda. (Black bar $=$ number of specimens captured.)

tures predominate between 300 and $600 \mathrm{~m}$, and the catches below $600 \mathrm{~m}$ presumably represent contamination.

The nighttime distribution shows 88 percent of the 74 specimens in the upper $200 \mathrm{~m}$. The few captures below this level probably are contaminants. Pterygioteuthis gemmata from California, therefore, appears to undergo a diel migration of about $300-400 \mathrm{~m}$ in vertical extent.

Another species of Pterygioteuthis, $P$. giardi, has been taken during the Ocean Acre cruises off Bermuda. One hundred four specimens of $P$. giardi were captured in closing net samples (Figure 5). During daytime, six specimens $(8-16 \mathrm{~mm}$ $M L)$ were captured, five from $327-475 \mathrm{~m}$ and one at $260 \mathrm{~m}(9 \mathrm{~mm} \mathrm{ML})$. At night 70 specimens (5-16 $\mathrm{mm} \mathrm{ML)} \mathrm{were} \mathrm{captured} \mathrm{between} 50$ and $175 \mathrm{~m}$; all but three were captured between 50 and $100 \mathrm{~m}$, and over 80 percent of the captures occurred at 50-60 m. Pterygioteuthis giardi, therefore, undergoes a diel vertical excursion of $250-300 \mathrm{~m}$. There is no apparent segregation of sizes during day or nighttime periods.

It is difficult to explain the large disparity between number of individuals captured in day vs night trawls. It is possible that there is an avoidance of the net during the daytime due to the greater light intensities or that the discrepancy reflects a greater dispersion of individuals during the day.

The Ancistrochirinae contains two species, one of which, Thelidioteuthis alessandrinii, may be a synonym of the other, Ancistrochirus lesueuri. 
Four larval and juvenile specimens (15-33 $\mathrm{mm}$ ML) of $T$. alessandrinii were captured by the Dana Expeditions on four separate occasions in less than $100 \mathrm{~m}$ at night. Two specimens $(20 \mathrm{~mm}$ and $21 \mathrm{~mm} \mathrm{ML)} \mathrm{were} \mathrm{taken} \mathrm{at} \mathrm{night} \mathrm{off} \mathrm{Bermuda}$ in closing nets in less than $125 \mathrm{~m}$. One specimen (35 mm ML) was taken in an open net at $80 \mathrm{~m}$ at night off Hawaii. The nighttime distribution of juveniles, at least, appears to be in the near-surface layers.

The preceding data on the family Enoploteuthidae demonstrate that several species undergo diel vertical migration of several hundred meters. Where known, all stages beyond the larval stage for a particular species appear to occupy the same depth zones; even individuals as small as $5 \mathrm{~mm}$ ML (e.g., Pyroteuthis margaritifera) may migrate with adults. While daytime captures are few or lacking for many species, nighttime captures of individuals of many other species in near-surface waters suggest that the migratory behavior demonstrated in a few species probably is very widespread in the family. Indeed, no evidence exists for nonmigratory behavior of any enoploteuthid species.

\section{OMMASTREPHIDAE}

Figure 26

We have relatively little additional information on the vertical distribution of this large and important family since Clarke (1966) reviewed much of the literature covering the subject.

Ommastrephes caroli, $O$. pteropus, and $O$. bartramii are frequently dipnetted at the surface at night (Clarke, 1966; Roper, 1963; Young, 1972a). A tentacle of $O$. caroli was caught by a reversing water bottle at $1490 \mathrm{~m}$, presumably during the night, and photographs, apparently of this species, were taken at night at 600 and $700 \mathrm{~m}$ (Clarke, 1966:108-109). Little is known about their daytime distribution. Baker (1960) reported that specimens of $\boldsymbol{O}$. pteropus (or $O$. caroli, see Clarke, 1966:109) were photographed and captured on long lines at $1000 \mathrm{~m}$ at night at the same time that other individuals of these species were being captured at the surface. These are prominant species at the surface at night except during periods of bright moonlight and rough seas (Baker, 1960). Arata (1954) observed squid, thought to be $O$. bartramii, leaping from the water and gliding for some distance over the water surface during the daytime.

Symplectoteuthis oualaniensis commonly is found at the surface at night (Clarke, 1966:115). Symplectoteuthis luminosa has also been reported from the surface at night (Young, 1972a:34). Nothing is known of the daytime distribution of these species.

Hyaloteuthis pelagica, distributed world-wide in warm waters, is a relatively infrequently captured ommastrephid. Off Bermuda, four specimens (12-24 mm ML) have been taken in closing nets at night at $100 \mathrm{~m}$. Open-net captures with a large Engel midwater trawl resulted in the capture of 85 specimens (10-90 mm ML, mostly 40-90 mm ML), 78 of which were taken at night; the remaining 7 were twilight captures. At night 56 specimens were taken at $150-0 \mathrm{~m}$; the remaining 22 specimens taken in trawls fishing at various depths to $1000 \mathrm{~m}$, probably are contaminants.

Dosidicus gigas commonly is seen at the surface at night (Clarke, 1966:117). We have seen motion pictures of this species leaping from the water during the day off Chile and attacking fishing lures at the surface during the day off Peru.

Ornithoteuthis antillarum has been reported at the surface at night (G. L. Voss, 1957). Sasaki $(1929: 285)$ reported that $O$. volatilis is referred to as flying squid by Japanese fishermen who report that it can glide over the surface of the sea.

Data are available on 43 adult specimens of $O$. antillarum from the western tropical Atlantic and Caribbean; all captures were made in bottomfishing otter trawls (21 tows) at depths of 585$1100 \mathrm{~m}$ (mostly 640-825 m), and all but three were captured during the day. The three possible nighttime captures were made in nets that fished through twilight periods as well as night. In the eastern south Atlantic, many specimens of $O$. cf. antillarum were captured at night over deep water in Engel trawls that fished between 100 and $600 \mathrm{~m}$. The significant preponderance of daytime vs nighttime captures in bottom trawls and the occurrence of specimens in midwater and at the surface at night suggest that Ornithoteuthis spends the day on or near the bottom and spreads out into middepths at night.

Illex illecebrosus generally is caught in shallow water 15-30 $\mathrm{m}$ deep during the summer. At the 
northern end of its range, off Newfoundland, these squid are occasionally seen at the surface (C. C. Lu, pers. comm.). Clarke (1966:119) stated that Illex illecebrosus is most numerous near the coast and probably lives on the upper slope and shelf.

Illex illecebrosus off the Chesapeake Bight has been captured with otter trawls at depths of 45-265 m; nearly all captures occur during the daytime indicating that specimens leave the bottom and disperse into midwater at night (C. C. Lu, pers. comm.). Milliman and Manheim (1968) observed dense concentrations (estimated to be 500 per $10^{3} \mathrm{~m}^{3}$ ) of squid off Cape Hatteras, North Carolina, thought to be Illex illecebrosus, from a submersible at depths of 220-250 $\mathrm{m}$ during the day over a bottom depth of $700 \mathrm{~m}$. C. R. Robins (University of Miami, pers. comm.) observed considerable numbers of squid, thought to be a species of Illex, from a submersible at approximately $900 \mathrm{~m}$ during daytime off Miami, Florida. Some of the squid were resting on the bottom while others were swimming immediately above the bottom.

Illex coindetti is closely associated with the bottom where it is fished at depths of about 40 to $500 \mathrm{~m}$ depending somewhat on the locality and season (Mangold-Wirz, 1963:157). In the Gulf of Guinea, I. coindetii has been captured in otter trawls from $80-410 \mathrm{~m}$ during the daylight hours; at night the specimens apparently leave the bottom and disperse into middepths (C. C. Lu, pers. comm.). Illex oxygonius from the western Atlantic has been taken from $50-550 \mathrm{~m}$ with bottom trawls (Roper, Lu, and Mangold, 1969:219); no information is available on day-night distributions. Todaropsis eblanae also is associated with the bottom and is fished at depths from $85-660 \mathrm{~m}$ (Mangold-Wirz, 1963:168).

Todarodes sagittatus frequently is found at the surface during the night, but during the day it can be fished with bottom trawls from 70-800 m (Clarke, 1966:129). It has been photographed at depths of $1000 \mathrm{~m}$ presumably far off the bottom (Clarke, 1966:129). Clarke and Merrett (1972) record fragments of $T$. sagittatus from the stomach of the bottom-living shark, Centroscymnus coelolepis, captured at $1975 \mathrm{~m}$.

Todarodes pacificus commonly is caught by jig and line at $20-30 \mathrm{~m}$ from the surface at night. During the day these squid descend to around
$100 \mathrm{~m}$ where they are occasionally fished by hand line (Suzuki, 1963:143).

Little information is available on the vertical distribution of species of the genus Nototodarus. Nototodarus sloani gouldi has been taken by dipnets (Cotton, 1942). In Hawaii, $N$. hawaiiensis appears to be associated with the ocean bottom as evidenced by occasional bottom photographs (400 $\mathrm{m}$ by $\mathrm{R}$. Grigg, University of Hawaii), otter trawl captures (400-570 m, ALBatross stations, vide Berry, 1914), and trap captures. During late summer months it can be captured at the surface at night off the island of Hawaii where it supports a minor dipnet fishery.

The ommastrephids exhibit a wide variety of vertical distributional patterns. Some species (e.g., Ommastrephes caroli) can roam from the surface to great depths. Others appear to be restricted to near surface waters (e.g., T. pacificus). A number of species are associated with the bottom, but approach the surface nightly during all or part of the year (e.g., T. sagittatus, N. hawaiiensis). Other species may move into shallow water seasonally during feeding migrations (e.g., I. illecebrosus).

\section{HISTIOTEUTHIDAE}

Figures 6, 27: BARS 1-4

The Histioteuthidae consists of 13 species in the single genus Histioteuthis (N. Voss, 1969). Since most species are represented by relatively few specimens captured in open nets from scattered localities, information on vertical distribution is sketchy.

Histioteuthis heteropsis from the California study is represented by 191 specimens larger than $6 \mathrm{~mm}$ ML taken in open nets (Figure 6). During the daytime 90 specimens were taken, none of which occurred in the upper $300 \mathrm{~m}$; 3 percent were taken in $300-400 \mathrm{~m}, 13$ percent in $400-500$ $\mathrm{m}, 38$ percent in $500-600 \mathrm{~m}, 24$ percent in 600 $700 \mathrm{~m}$, and 10 percent in $700-800 \mathrm{~m}$. The remaining 12 percent were scattered between 800 and $1200 \mathrm{~m}$ and probably represent contamination. The upper limit for the majority of the daytime captures is $400 \mathrm{~m}$ and the lower limit lies around $800 \mathrm{~m}$. Peak abundance occurs between $500 \mathrm{~m}$ and $700 \mathrm{~m}$.

At nighttime 69 percent of the 101 specimens 


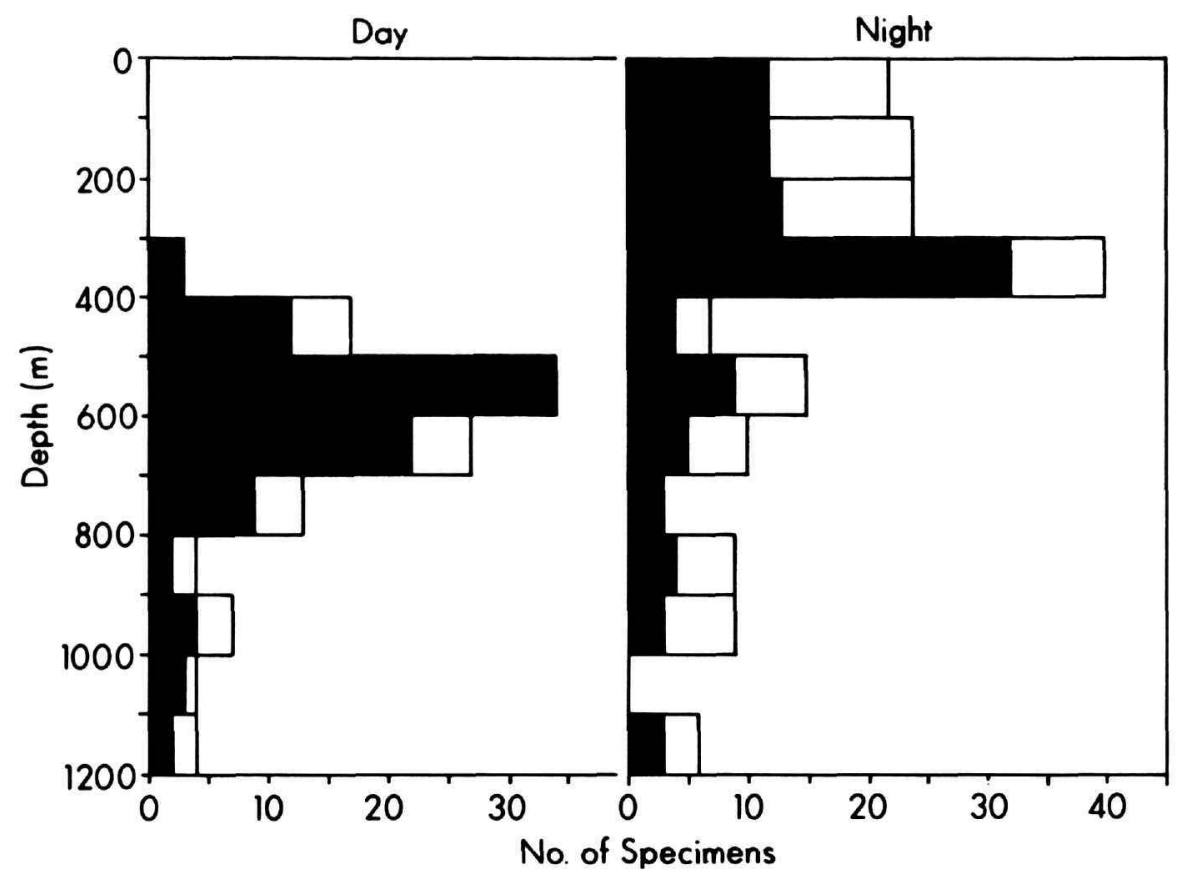

Figure 6.-Vertical distribution of Histioteuthis heteropsis off southern California. (Black bar $=$ number of specimens captured; white bar $=$ correction factor.)

captured were taken in the upper $400 \mathrm{~m}$ with a peak at 300-400 meters; 21 percent from $400-800$ $\mathrm{m}$, and 10 percent from $800-1200 \mathrm{~m}$. Possibly all specimens from below $400 \mathrm{~m}$ are contaminants. The shallowest capture at night for specimens larger than $20 \mathrm{~mm}$ ML was $200 \mathrm{~m}$ and most were concentrated at $300-400 \mathrm{~m}$. This species undergoes a diel vertical migration of 300 to $400 \mathrm{~m}$.

From off Bermuda closing net captures of $\boldsymbol{H}$. dofleini were made during the day at $510 \mathrm{~m}$ (14 $\mathrm{mm} \mathrm{ML})$ and at night at $50 \mathrm{~m}$ (12 $\mathrm{mm} \mathrm{ML})$. One $H$. meleagroteuthis ( $16 \mathrm{~mm} \mathrm{ML}$ ) was captured at $690 \mathrm{~m}$ during the day and another ( $32 \mathrm{~mm} \mathrm{ML}$ ) was taken at $360 \mathrm{~m}$ at night. Two specimens of H. corona ( $25 \mathrm{~mm}$ and $27 \mathrm{~mm} \mathrm{ML}$ ) were captured during the day at $630 \mathrm{~m}$. We suspect that a diel vertical migration pattern probably is widespread in this family.

\section{PSYCHROTEUTHIDAE}

The family consists of a single genus, Psychroteuthis, which contains two species (one unde- scribed) that occur in Antarctic waters and, possibly, a third species from off the Bonin Islands (Roper and Young, 1972:220). A large specimen was taken through an ice hole in the Antarctic and other specimens are known from midwater trawl captures. Nothing definitive, however, is known of the vertical distribution of these species.

\section{NEOTEUTHIDAE}

FIGURE 29: BAR 1

Two genera are known in the Neoteuthidae, Neoteuthis and Alluroteuthis. Alluroteuthis antarcticus is a pelagic species abundant in Antarctic waters, but little information currently is available on its vertical distribution.

Neoteuthis thielei is known from only a few specimens that have been captured in open midwater trawls. Off California one specimen $(83 \mathrm{~mm}$ ML) was taken at $1333-0 \mathrm{~m}$. In the eastern tropical Atlantic eight specimens (ca. 36-125 mm ML) of Neoteuthis sp. were taken at night in open 
Engel trawls that fished at $1750-2000 \mathrm{~m}$; one specimen (ca. $130 \mathrm{~mm} \mathrm{ML}$ ) was taken at $1300-0 \mathrm{~m}$ at night. In the Gulf of Mexico a specimen (ca. 50 $\mathrm{mm} \mathrm{ML}$ ) was taken at night at $900 \mathrm{~m}$ in a closing net.

\section{ARCHITEUTHIDAE}

The Architeuthidae consists of 20 nominal species of Architeuthis, most of which are undoubtedly synonymous. Although the giant squid has received a great deal of attention in the literature, very little is known of its vertical distribution or of any other aspect of its biology. Occasionally Architeuthis has been sighted (F. A. Aldrich, Memorial University of Newfoundland, pers. comm.) or captured alive at or near the surface (Verrill, 1882a:181), but these sightings may be unrepresentative of its habitat. The great majority of specimens come from strandings or whale stomachs. Perhaps the most significant capture is that reported by Cadenat (1936) of a specimen taken in a bottom trawl that fished at about $200 \mathrm{~m}$. Clarke and Merrett (1972) record fragments of Architeuthis sp. from the stomach of the deep-sea shark, Centroscymnus coelolepis, which was captured on a bottom-set long line at $1246 \mathrm{~m}$.

Two juvenile specimens of Architeuthis were taken from stomach contents of the oceanic fish Alepisaurus ferox (Roper and Young, 1972); this fish is thought to hunt primarily in the upper 300 $m$ of the open ocean (Rancurel, 1970:82), so it seems probable that the young Architeuthis occur within this range.

\section{BATHYTEUTHIDAE}

Figures 7, 27: BARS 5-7

The Bathyteuthidae consists of three species in the genus Bathyteuthis. Details of the distribution of these bathypelagic species are reported by Roper (1969).

Bathyteuthis abyssicola is a very commonly caught species in Antarctic waters and it occurs less abundantly in other areas of the world ocean; its maximum distribution appears to be directly associated with areas of relatively high organic productivity at the surface of the sea and with waters of $1^{\circ}-5^{\circ} \mathrm{C}$. In the Antarctic 563 specimens were analyzed (Figure 7). All specimens were captured in open net trawls; 87 percent of the captures occurred between 1000 and $2500 \mathrm{~m}$, and the remainder were taken between 500 and 1000 m. A very few captures occurred below $2500 \mathrm{~m}$ and are considered to be contaminants. Of the total captures, 60 percent (340 specimens) occur between 1500 and $2500 \mathrm{~m}$.

No diel vertical movements are known to occur. Larger animals tend to occur at greater depths than smaller individuals. Sixty-one percent of the specimens less than $300 \mathrm{~mm}$ ML live between 500 $1500 \mathrm{~m}$, while 72.5 percent of those larger than $30 \mathrm{~mm}$ ML live between 1500-2500 m.

One specimen of $B$. abyssicola (30 $\mathrm{mm} \mathrm{ML})$

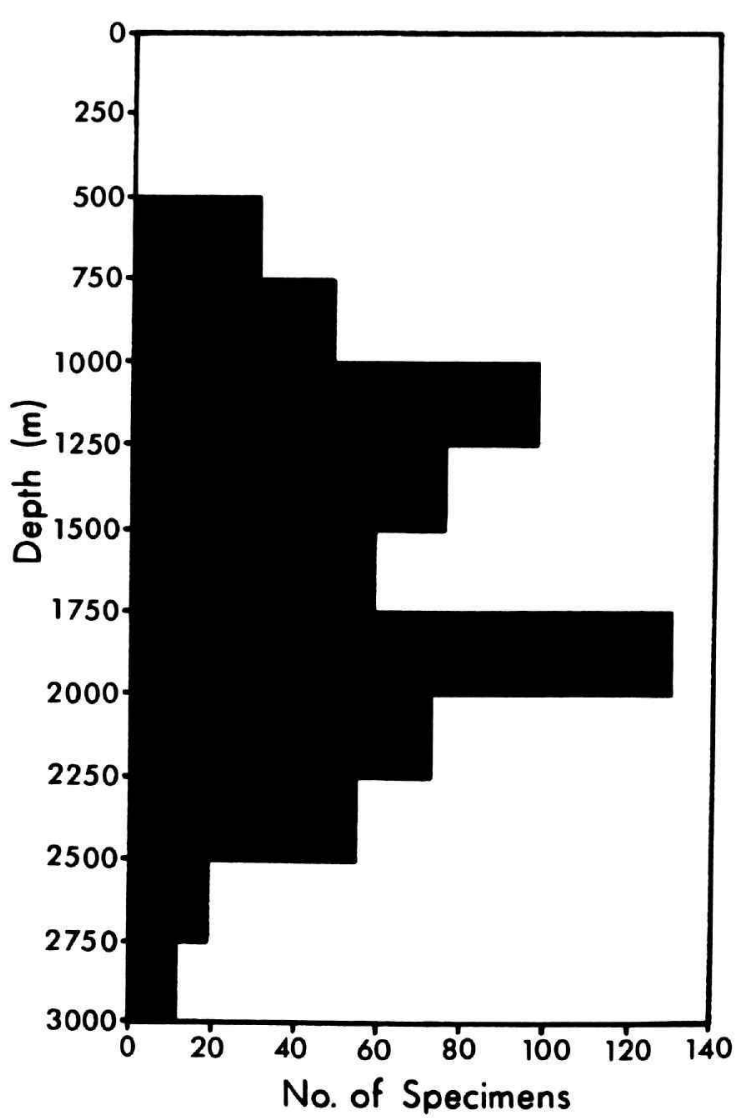

FIGURE 7.-Vertical distribution of Bathyteuthis abyssicola from Antarctic waters. (Black bar $=$ number of specimens per standardized 2-hour tow.) 
was captured in a closing net that fished between 830 and $975 \mathrm{~m}$ during the day off Hawaii.

Bathyteuthis bacidifera has been taken between 680 and $1550 \mathrm{~m}$ from the tropical eastern Pacific in open nets. Bathyteuthis berryi from off California has been captured between 800 and $1200 \mathrm{~m}$ in open nets and probably occurs much deeper, but data on deep water captures are lacking.

\section{GONATIDAE}

FIGURES 8-12, 27: BARS 8-14

Members of the Gonatidae inhabit primarily high latitude waters (Nesis, 1971a). Three genera presently are known; Gonatus, Gonatopsis, and Berryteuthis, although recent work has made the generic boundaries uncertain (Okiyama, 1969; Fields and Gauley, 1971; Nesis, 1971b).

Gonatus onyx was the most abundant species taken in the California study. Seven hundred and seventy-four specimens over $21 \mathrm{~mm}$ ML from open trawls were used in determining patterns of vertical distribution (Figure 8).

Less than 2 percent of the 438 daytime captures were shallower than $400 \mathrm{~m} ; 87$ percent of the specimens were taken in a zone between 400 and $800 \mathrm{~m}$. Specimens captured below $800 \mathrm{~m}$ are probably contaminants.

At night 3 percent of the 336 specimens were taken in the upper $100 \mathrm{~m} ; 11$ percent in 100-200 $\mathrm{m}, 5$ percent in $200-300 \mathrm{~m}, 18$ percent in $300-400$ $\mathrm{m}$, and 48 percent in $400-500 \mathrm{~m}$. The remaining 12 percent below $500 \mathrm{~m}$ probably represent contamination. Thirty-seven percent of the nighttime captures were taken from the water above the upper limit of the daytime captures $(400 \mathrm{~m})$, and the lower limit of the nighttime distribution appears to be $300 \mathrm{~m}$ shallower than the lower limit of the daytime distribution.

This species apparently shifts upward at night primarily into the $300-500 \mathrm{~m}$ zone, but ranges into the upper $100 \mathrm{~m}$. Trawls that caught Gonatus onyx during the day between 400 and $800 \mathrm{~m}$ averaged 16.8 specimens per tow. At nighttime between 300 and $500 \mathrm{~m}$ the average catch was 16.0 , while between 0 and $300 \mathrm{~m}$ the average was only 4.0.

Gonatus californiensis was the least abundant member of the genus in the California study. Of the 99 specimens larger than $20 \mathrm{~mm} \mathrm{ML}, 46$ were twilight captures unsuitable for plotting diel ver-

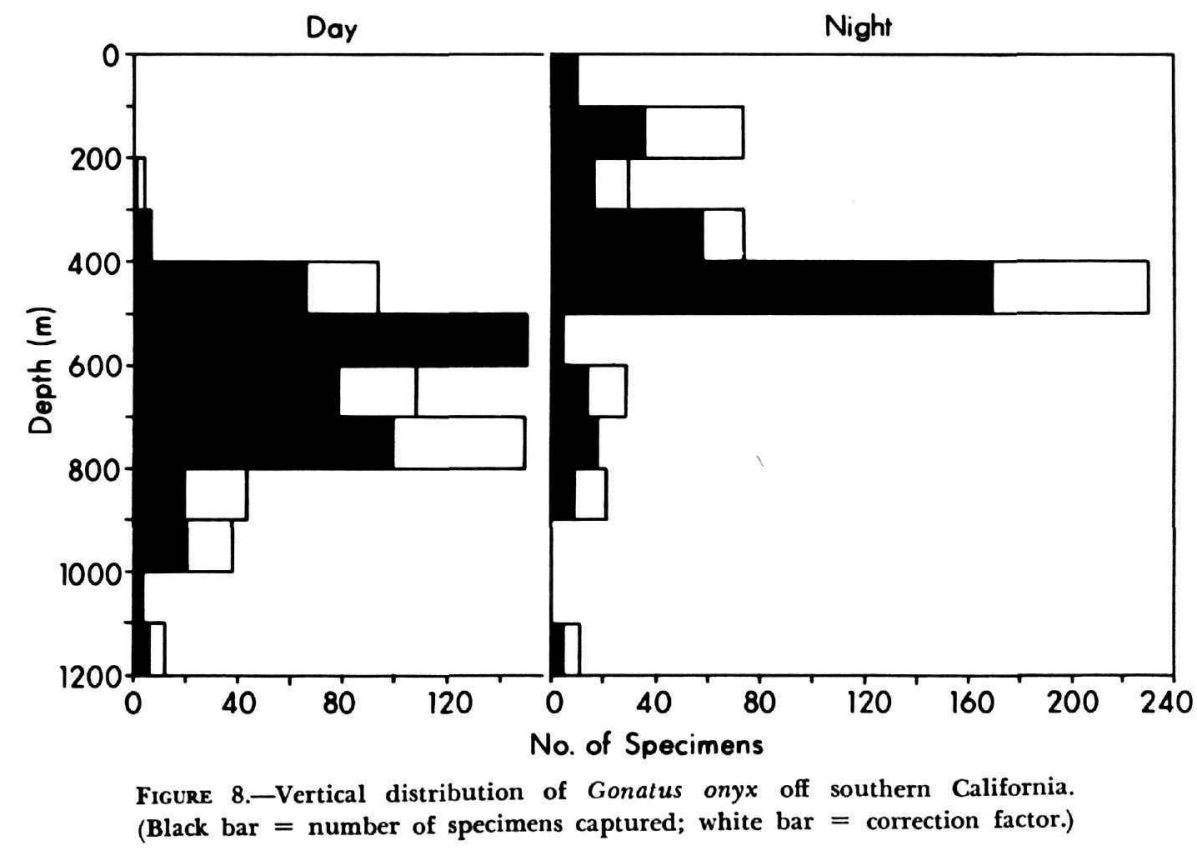


tical distribution. The data are difficult to interpret and for this reason the figure showing total captures (day, night, twilight) is included with the day and night distribution figures (Figure 9). During the daytime no specimens were captured above $400 \mathrm{~m}$. Seventy percent of the 30 daytime captures were taken in the zone from $400-800 \mathrm{~m}$ with the greatest proportion, 30 percent, occurring at the $700-800 \mathrm{~m}$ level. The remaining 30 percent is scattered from $800-1200 \mathrm{~m}$ and may represent contamination. Even though the daylight captures are few, the upper and lower limits of the daytime distribution appear to be at 400 and $800 \mathrm{~m}$, respectively, if twilight captures are considered. Eighty-eight percent of the combined daytime and twilight captures occurred between 400 and $800 \mathrm{~m}$.

Only 23 specimens were suitable for the nighttime analysis. Thirty-five percent were taken from
$100-400 \mathrm{~m}$ and 61 percent from $400-800 \mathrm{~m}$; a slight peak (48 percent of the night specimens) occurs between 300 and $500 \mathrm{~m}$. While the number of specimens is inadequate to allow definite conclusions, this species seems to undergo an upward shift at night.

Eighty-eight specimens of Gonatus pyros over $20 \mathrm{~mm} \mathrm{ML}$ are available from the California study (Figure 10). Only a single specimen was captured above $400 \mathrm{~m}$ during the daytime; 86 percent of the 52 daytime captures were taken in a zone between $400-700 \mathrm{~m}$. The few specimens captured below $700 \mathrm{~m}$ probably are contaminants. The daytime distribution of this species appears to be between $400 \mathrm{~m}$ and $700 \mathrm{~m}$.

Thirty-six specimens were taken during the nighttime; 14 percent in $100-200 \mathrm{~m}, 6$ percent in $200-300 \mathrm{~m}, 42$ percent in $300-400 \mathrm{~m}$, and 17 per-

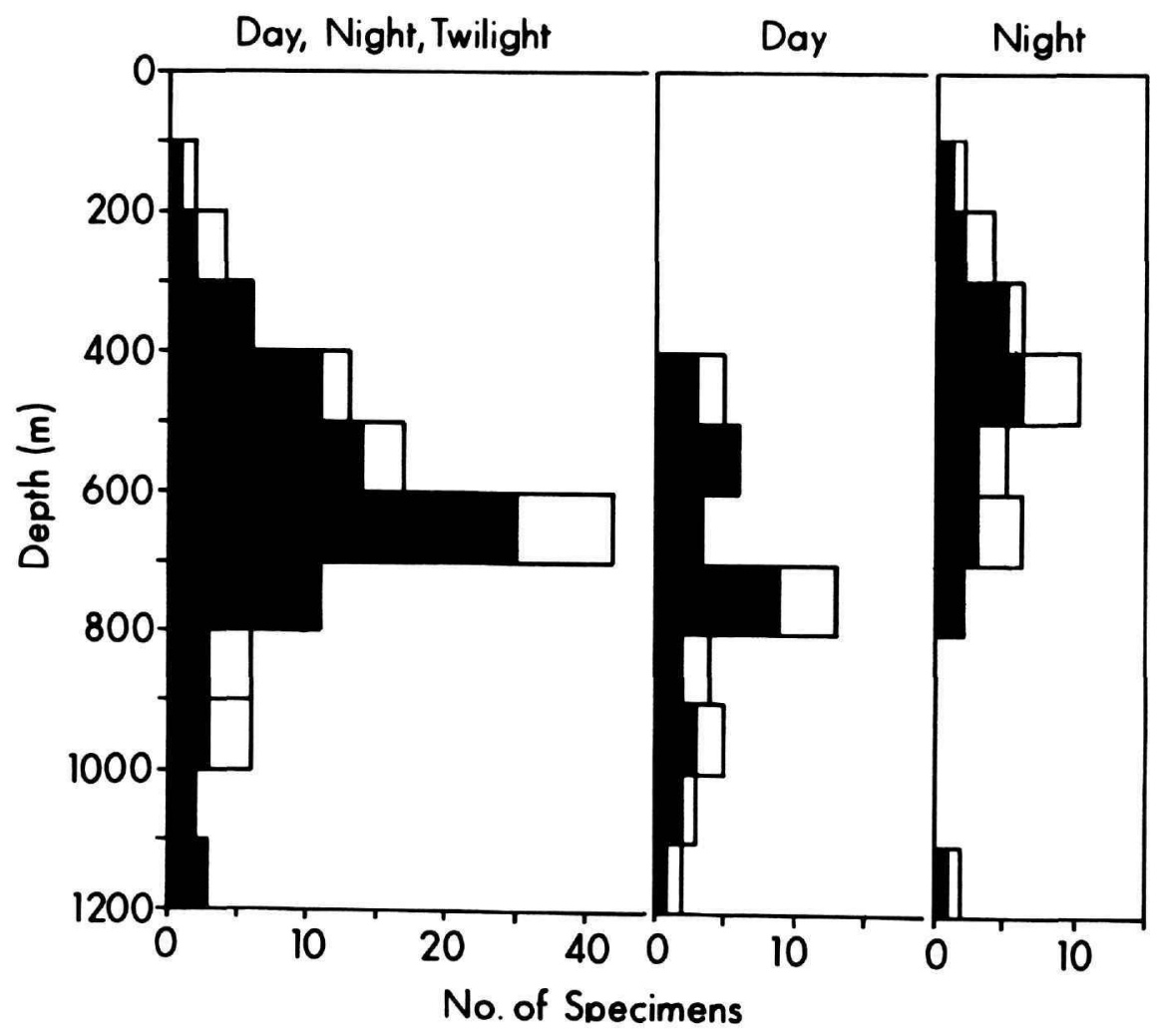

Figure 9.-Vertical distribution of Gonatus californiensis off southern California. (Black bar = number of specimens captured; white bar = correction factor.) 
cent in $400-500 \mathrm{~m}$. The remaining 21 percent of the specimens below $500 \mathrm{~m}$ possibly are contaminants. Therefore, the limited data suggest that the nighttime distribution has an upper limit at $100 \mathrm{~m}$ and a lower limit at $500 \mathrm{~m}$, although most captures were at $300-400 \mathrm{~m}$; this indicates that the species shifts upward at night.

Eighty-seven specimens of Gonatus berryi from off California were suitable for plotting vertical distribution. Although fairly common, this species is never caught in large numbers. The larvae of $G$. berryi differ morphologically from the larvae of the other three species of Gonatus in the area studied, and this is reflected in their deeper living habit. The distribution of larvae (6-15 mm ML) shows a peak between 300 and $700 \mathrm{~m}$ (Figure 11). This range is slightly shallower than that found for the larger animals.

No subadult specimens were captured in less than $300 \mathrm{~m}$ during the daytime. A single specimen each was captured in the $300-400 \mathrm{~m}$ zone and the 400-500 m zone; 68 percent of the catch was in the $500-800 \mathrm{~m}$ zone, while the remaining specimens below $800 \mathrm{~m}$ probably represent contamination. Therefore, the daytime distribution seems to lie between 500 and $800 \mathrm{~m}$. A large number of captures in the $400-500 \mathrm{~m}$ zone was made in tows that extended into the twilight period; many of these probably entered the net during daytime, so the upper limit may be at $400 \mathrm{~m}$ instead of $500 \mathrm{~m}$.

At nighttime no specimens were taken in the upper $100 \mathrm{~m}$; one was taken in $100-200 \mathrm{~m}$, three in $200-300 \mathrm{~m}$, and one in $300-400 \mathrm{~m}$. The greatest concentration is in the $400-500 \mathrm{~m}$ zone where 33 percent of the specimens were taken, while 30 percent were taken between $500-800 \mathrm{~m}$. While there might be a slight upward shift in the peak of abundance at night, it is not as apparent as in the other species of Gonatus. The number of captures attributed to depths below $800 \mathrm{~m}$ during both daytime and nighttime is considerably higher than is found in the other three species of Gonatus. Although much of this undoubtedly is contamination, a small percentage of the population probably extends to the lower limit $(1200 \mathrm{~m})$ of the sampling program. Church (1971) observed a specimen of Gonatus, apparently berryi, from a deep-diving submersible at $915 \mathrm{~m}$.

Gonatopsis borealis from off California was represented by 74 juvenile specimens between 16 and
$47 \mathrm{~mm} \mathrm{ML} \mathrm{(Figure} \mathrm{12).} \mathrm{No} \mathrm{specimens} \mathrm{were} \mathrm{cap-}$ tured during the daytime in the upper $300 \mathrm{~m}$ and only a single specimen was taken in the $300-400 \mathrm{~m}$ zone. Ninety percent of the daytime captures occurred at $400-700 \mathrm{~m}$, while 8 percent, probably contaminants, were captured below $700 \mathrm{~m}$. Therefore, the distribution in the daytime seems to be between 400 and $700 \mathrm{~m}$.

Only a few specimens were captured at night; three in the upper $200 \mathrm{~m}$, six in $200-400 \mathrm{~m}$, one in $400-500 \mathrm{~m}$, and three, probably contaminants, in $800-1000 \mathrm{~m}$. The scanty evidence suggests that the nighttime distribution is in the upper $400 \mathrm{~m}$. If this is correct, $G$. borealis undergoes vertical migration of 200-300 m, at least during the juvenile stage.

Fourteen specimens of Berryteuthis magister are available from the Auke Bay region of Alaska. Some specimens were captured in otter trawls at depths that ranged from $165-310 \mathrm{~m}$ during both day and night. The specimens had the following mantle lengths (in $\mathrm{mm}$ ): 69, 73, 100, 152, 192, 200, 210, 250. Three specimens $(57,75$, and $90 \mathrm{~mm}$

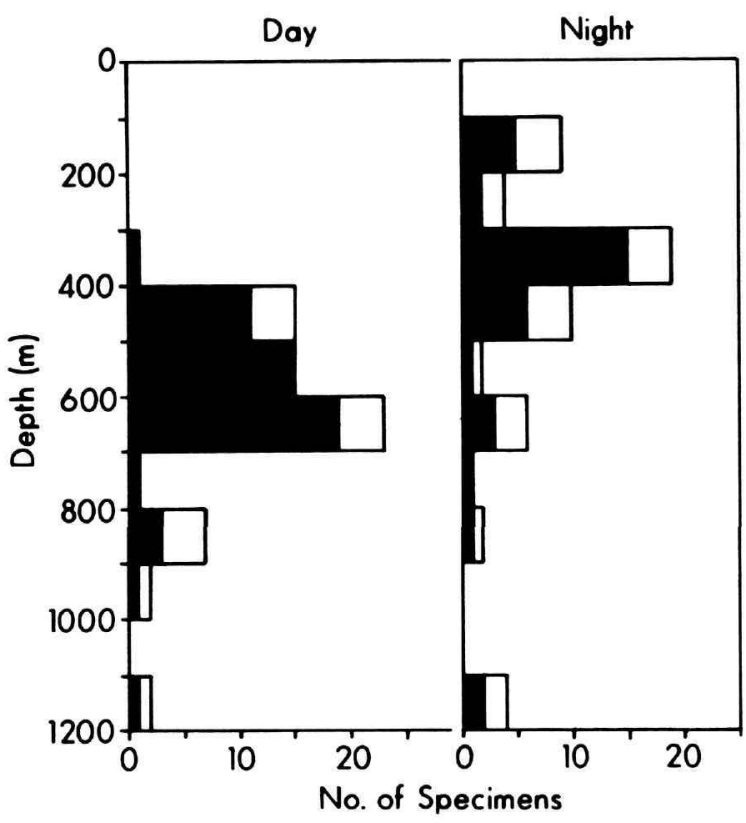

Figure 10.-Vertical distribution of Gonatus pyros off southern California. (Black bar $=$ number of specimens captured; white bar $=$ correction factor.) 
ML) were taken in Isaacs-Kidd midwater trawls at night between $3-5 \mathrm{~m}$, and 3 others $(62,124$, and $173 \mathrm{~mm} \mathrm{ML}$ ) were taken at or near the surface in a herring seine and salmon traps. Sasaki (1929:272) records $B$. magister from $180,725,820$, and $1000 \mathrm{~m}$, in bottom trawls off Japan, Korea, and the Bering Sea.

Berryteuthis anonychus has been recorded (as Gonatus anonychus) only from specimens that were captured at the surface at night off Oregon (Pearcy and Voss, 1963).

Three of the four species of Gonatus (G. pyros, G. onyx, G. californiensis) for which we have data, exhibit very similar distributional patterns, in which they appear to undergo a slight upward shift in their vertical distributions at night. The absence of strong vertical migrations in these species is somewhat surprising, because they are among the more muscular midwater squids. It is possible that the fourth species ( $G$. berryi) does not migrate vertically. Juvenile Gonatopsis berryi seem to exhibit a more pronounced upward shift, but nighttime data are insufficient to confirm this.

Berryteuthis magister has been taken many times in bottom trawls and probably spends some time associated with the ocean bottom.

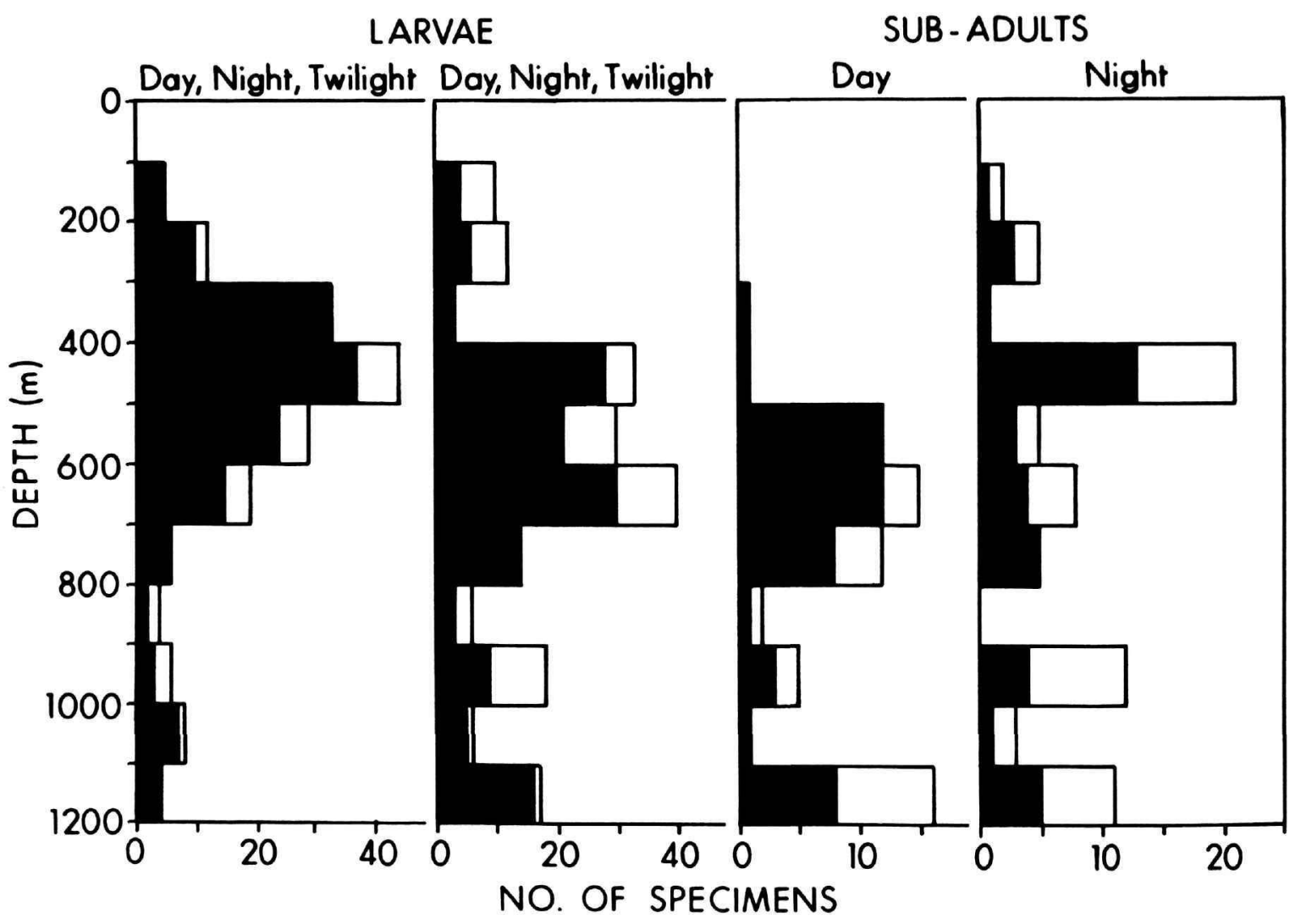

Figure 11.-Vertical distribution of Gonatus berryi off southern California. (Black bar = number of specimens captured; white bar $=$ correction factor.) 


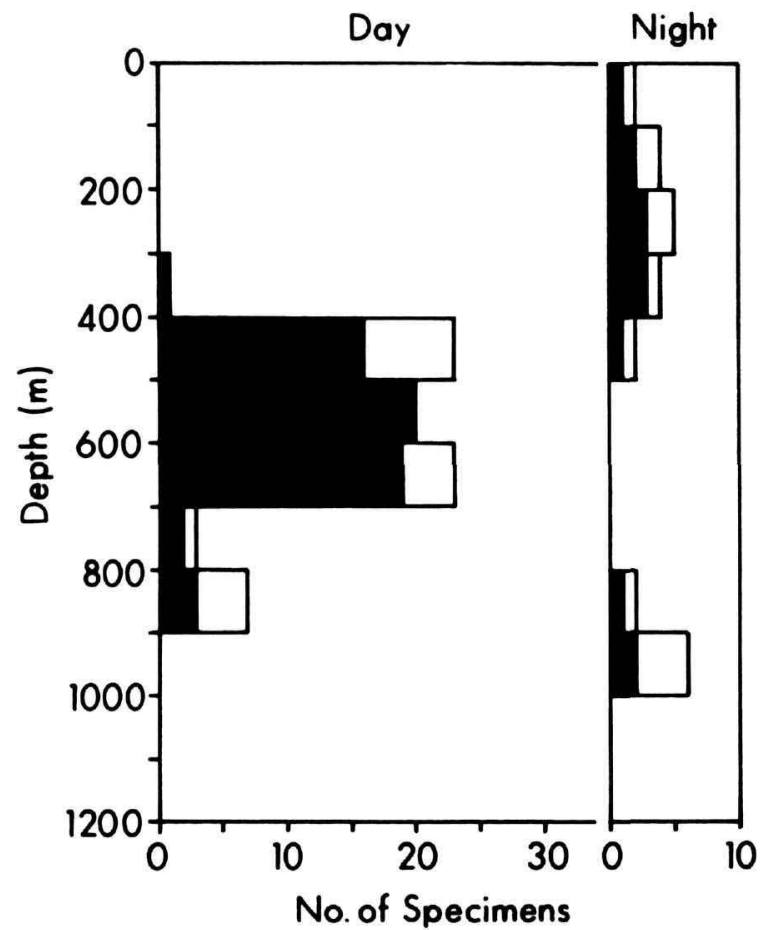

FIGURE 12.-Vertical distribution of Gonatopsis borealis off southern California. (Black bar $=$ number of specimens captured; white bar $=$ correction factor.)

\section{OCTOPOTEUTHIDAE}

Figures 13, 28: Bars 5, 6

The Octopoteuthidae consists of two genera, Octopoteuthis and Taningia.

Eighty-three specimens larger than $15 \mathrm{~mm} \mathrm{ML}$ of Octopoteuthis deletron from California were analyzed (Figures 13, 28:bar 5). Only about half as many specimens (26) were captured during the daytime as at night. During the day, no specimens were captured in the upper $200 \mathrm{~m}$. The greatest number of captures occurs between 300 and $400 \mathrm{~m}$ where 13 specimens $(50$ percent $)$ were taken (when the amount of trawling at different depths is equalized, the greatest abundance would be at 200-300 m). Three specimens each were taken in $400-500 \mathrm{~m}, 500-600 \mathrm{~m}$, and $600-700 \mathrm{~m}$; a single specimen was taken in $700-800 \mathrm{~m}$, and three between 1000 and $1200 \mathrm{~m}$. The daytime upper limit is clearly at $200 \mathrm{~m}$, but the lower limit is more difficult to determine.
Fifty-seven specimens were captured at night, the majority of which were fairly evenly distributed throughout the upper $500 \mathrm{~m} ; 23$ percent in the upper $100 \mathrm{~m}, 14$ percent in $100-200 \mathrm{~m}, 11$ percent in $200-300 \mathrm{~m}, 21$ percent in $300-400 \mathrm{~m}$, and 12 percent in $400-500 \mathrm{~m}$. The remaining 19 percent was distributed from $600-1200 \mathrm{~m}$ and probably represents contamination from shallower zones.

Certainly additional information is needed, but the available data indicate that the species does not undergo a "typical" diel vertical migration, but seems to spread out over a greater range of depths during the night than during the day.

The largest Octopoteuthis (20 mm ML) taken off Bermuda in closing nets was captured at $230 \mathrm{~m}$ at night.

Little information exists on Taningia danae, the only species in the genus. Taningia danae grows to a large size of at least $140 \mathrm{~cm}$ ML (Clarke, 1967, table 1). A few juveniles have been captured at night within $175 \mathrm{~m}$ of the surface (Clarke, 1967: 127). Remains of a large $T$. danae, estimated to approach $50 \mathrm{~kg}$, were taken from the stomach of the bottom-living shark, Centroscymnus coelolepis,

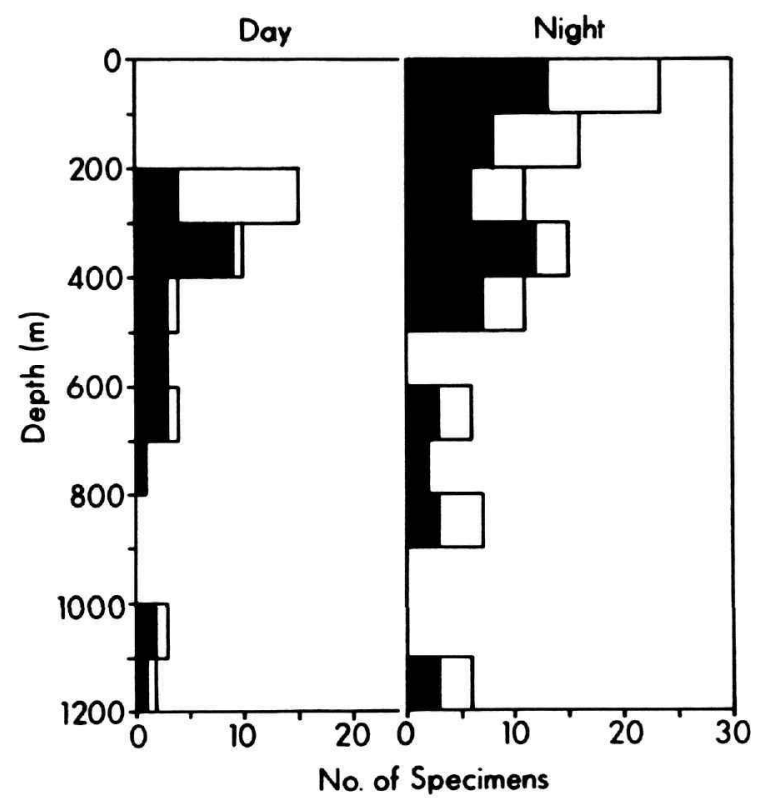

Figure 13.-Vertical distribution of Octopoteuthis deletron off southern California. (Black bar $=$ number of specimens captured; white bar $=$ correction factor.) 
captured on a bottom-set long line at $1246 \mathrm{~m}$ (Clarke and Merrett, 1972). Otherwise, nothing definitive is known of the distribution of the larger animals.

\section{ONYCHOTEUTHIDAE}

FIGURE 28: BARS 2-4

The family Onychoteuthidae contains five genera, the best known of which is Onychoteuthis. Onychoteuthis banksii occasionally is found on the decks of ships in the morning (Rees, 1949) and individuals are frequently observed and dipnetted at the surface at night (personal observations). The animals are powerful swimmers and adults only rarely are caught in nets.

Off Bermuda, 52 specimens of Onychoteuthis banksii (5-57 mm ML) were taken in closing net samples. Captures were made from the surface to a maximum depth of $150 \mathrm{~m}$; all but two specimens were taken in the $50-100 \mathrm{~m}$ zone both day and night. The largest specimen was taken at the surface at .ight. All daytime captures from Ocean Acre are small individuals which may not have adopted the juvenile or adult pattern of distribution; thus little can be determined concerning daytime distribution. However, a specimen of 20 $\mathrm{mm}$ ML was taken from a depth of $800 \mathrm{~m}$ in midday in the Mediterranean in a closing trawl. Although it is possible that this was a contaminant, examination of the photosensitive vesicles of Onychoteuthis, which are rather elaborate, suggests that this animal is not restricted to epipelagic regions.

Onykia caribaea is a relatively small species that has been taken primarily at the surface both during the day and at night. It is commonly associated with Sargassum, the floating seaweed (Lesueur, 1821; Bullen, 1899; personal observations). Onykia caribaea has a bluish coloration on the dorsal surface that is characteristic of species of the neuston (Herring, 1967:220). One specimen of $O$. caribaea (34 mm ML) from St. Helena was regurgitated from the stomach of a Fairy tern which feeds only at the surface.

Ten closing net captures of juvenile $O$. caribaea have been made during the Ocean Acre cruises and all specimens were taken at the surface both during the day and at night.
Chaunoteuthis mollis is known from only a few specimens, several of which were taken dead at the surface (Clarke, 1966:149).

The vertical distribution of Ancistroteuthis lichtensteini, a rarely caught species, cannot be determined on the basis of the scant information available.

Several nominal species of Moroteuthis exist, the best known of which is $M$. robusta from the north Pacific. Records are available from the bottom trawl fisheries off the west coast of North America from central California to Vancouver. Specimens recorded in the literature have been taken in otter trawls that fished at the following depths (in meters): 165-275, 250-280, 295, 320, 340 (2 stations), 350, 370 (3 stations), 400 (2 stations), 460, and 550 (Pattie, 1968; van Hyning and Magill, 1964; Smith, 1963). One specimen was captured by skin divers in shallow water in central California, which presumably is an abnormally shallow occurrence for this species, since the shallow water fisheries have failed to yield additional shallow water records.

R. R. Talmadge (pers. comm.), utilizing information and specimens provided by sole fishermen, reports that a specimen of $M$. robusta was captured at $100 \mathrm{~m}$ and that specimens are commonly captured from $200-275 \mathrm{~m}$ on down to $375 \mathrm{~m}$. The currently known distribution may well be incomplete, in that it reflects only the depths at which fishermen concentrate their fishing efforts for various species of sole. Fishermen report that $M$. robusta may be caught both during day and night, and that no correlation between depth of capture and time of day seems to exist. Although most captures occur in the fall (August to November), specimens may be caught throughout the year. Occurrence in northern Californian waters appears to be cyclic and the species may be absent one year and abundant the next.

Currently, sufficient data are lacking to indicate the deeper boundary of $\boldsymbol{M}$. robusta, although the upper limit appears to be around $100 \mathrm{~m}$. Since all captures have been made by bottom trawls, it is probable that this species is associated with the bottom, at least part of the time. Furthermore, about half of the specimens examined by Talmadge (pers. comm.) contained in their stomachs fragments of the sea urchin, Briaster townsendii 
which lives on mud bottom from about $275 \mathrm{~m}$ to $900 \mathrm{~m}$.

In summary, little can be said about the vertical distribution of most species of onychoteuthids. It is clear that Onychoteuthis banksii occurs in surface waters at night. Onykia caribaea apparently is restricted to surface waters both during the day and night. As with many ommastrephids and loliginids, Moroteuthis robusta seems to associate with the ocean bottom at least part of the time. Almost no information is available on the distribution of Chaunoteuthis and Ancistroteuthis.

\section{THYSANOTEUTHIDAE}

FIGURE 28: BAR 1

Thysanoteuthis rhombus is a world-wide oceanic species in lower latitudes. In the Japan Sea it is taken in set nets during the fall and early winter in near-shore waters (Nishimura, 1966:329); it is caught in greater abundance during the night but daytime captures are relatively common. We have a juvenile specimen of $T$. rhombus (25 mm ML) that was captured in the open ocean (bottom depth $2750 \mathrm{~m}$ ) in an open midwater trawl that fished during the day at $35-55 \mathrm{~m}$.

\section{CYCLOTEUTHIDAE}

FigUre 28: BARS 7-9

This family contains three (possibly four) species in two genera, Cycloteuthis and Discoteuthis; each species is known from only a few specimens. Five specimens of Cycloteuthis sirventi (17-134 mm ML) have been caught at $650-0 \mathrm{~m}$ during the day; $140-0 \mathrm{~m}, 150-0 \mathrm{~m}$, and $100-0 \mathrm{~m}$ at night and 200-0 $\mathrm{m}$ at twilight in open nets. Five specimens of Discoteuthis discus (24-53 $\mathrm{mm} \mathrm{ML})$, were captured at 750-0 $\mathrm{m}$ and $450-0 \mathrm{~m}$ during the day; $400-0$ and $100-0 \mathrm{~m}$ at night, and $600-0 \mathrm{~m}$ (time unknown). These records have been taken from scattered localities throughout the north Atlantic (Young and Roper, 1969a). Two adults have been taken off Bermuda in open nets at depths of 140-0 $\mathrm{m}$ and $950-0 \mathrm{~m}$, at night.

Discoteuthis laciniosa (19-134 $\mathrm{mm} \mathrm{ML)} \mathrm{has}$ been taken in open nets that fished at $425-0 \mathrm{~m}$, 725-0 $\mathrm{m}, 950-0 \mathrm{~m}$, and $1060-0 \mathrm{~m}$ during the day and at $160-0 \mathrm{~m}, 350-0 \mathrm{~m}, 500-0 \mathrm{~m}, 750-0 \mathrm{~m} \mathrm{(2}$ specimens) and $1200-0 \mathrm{~m}$ at night. D. laciniosa has been taken off Hawaii in open nets at 900-0 m during the day (55 mm ML) and 215-0 $\mathrm{m}$ at night (40 $\mathrm{mm}$ and $50 \mathrm{~mm} \mathrm{ML}$ ). Several specimens were recently captured in a closing net at $650 \mathrm{~m}$ during the day.

With broad scatter of depth-points for the cycloteuthid species, little can be said about their vertical distributions; however, all three species have been captured in the upper $200 \mathrm{~m}$ at night.

\section{CTENOPTERYGIDAE}

FIGURE 28: BAR 10

The single genus, Ctenopteryx, is comprised of several nominal species. Little is known concerning their vertical distribution. From the Mediterranean two specimens (19 and $35 \mathrm{~mm} \mathrm{ML}$ ) of $C$. sicula were captured in closing nets at night between 100 and $150 \mathrm{~m}$. Off Bermuda a single specimen of $C$. sicula (22 mm ML) was taken at $100 \mathrm{~m}$ at night in a closing net. Off Hawaii four specimens of Ctenopteryx sp. (23-35 mm ML) have been taken at night from $100-0 \mathrm{~m}$. These species appear to inhabit the near-surface waters at night.

During the day only three closing net records are available. Off Bermuda two specimens (12 and $14 \mathrm{~mm} \mathrm{ML)}$ were caught at $350 \mathrm{~m}$. In the Mediterranean one specimen (12 mm ML) was taken at $150 \mathrm{~m}$. Off Hawaii five specimens (20-29 mm ML) have been taken in open nets between $600-0 \mathrm{~m}$ and $800-0 \mathrm{~m}$ during the day.

In the Atlantic Ocean in open nets three specimens (38-62 mm ML) were taken at 850-0 $\mathrm{m}$ and 1000-0 $\mathrm{m}$ during the day; at night 10 specimens (20-58 mm ML) were taken at 100-300 m, five specimens (20-77 $\mathrm{mm} \mathrm{ML}$ ) at $600-800 \mathrm{~m}$, and five specimens (42-83 mm ML) at 1300-2000 m.

\section{BRACHIOTEUTHIDAE}

Figure 29: BAR 2

The family contains a single genus and an indeterminate number of species. Very little is known of the vertical distribution of any species.

Two specimens of Brachioteuthis sp. were taken in closing nets off Hawaii, one at 830-975 m during 
the day (38 mm ML) and one at 100-150 $\mathrm{m}$ at night. Open net captures of four specimens were taken at 975-1000 $\mathrm{m}$ during the day (38 $\mathrm{mm}$ and $42 \mathrm{~mm} \mathrm{ML}$ ) and at $50 \mathrm{~m}$ and $225 \mathrm{~m}$ during the night (33 $\mathrm{mm}$ and $47 \mathrm{~mm} \mathrm{ML}$ ). In the Mediterranean three specimens (34-63 $\mathrm{mm}$ ML) of Brachioteuthis sp. were captured in closing nets at $150 \mathrm{~m}$ during the night. The meager data suggest that Brachioteuthis spp. undergo extensive diel vertical migration.

\section{LEPIDOTEUTHIDAE}

FIGURE 28: BARS 11-13

The family tentatively consists of the genera Lepidoteuthis, Pholidoteuthis, and Tetronychoteuthis. Few reliable records of vertical distribution are available for these genera.

Two juvenile Lepidoteuthis grimaldii (60 and $84 \mathrm{~mm} \mathrm{ML}$ ) have been taken at night in open midwater trawls that fished from 270-0 m (Clarke, 1964). A specimen (190 mm ML) was taken in an Engel trawl at $700-0 \mathrm{~m}$ at night in the south Atlantic. Off Bermuda one juvenile ( $35 \mathrm{~mm} \mathrm{ML}$ ) was captured in a closing net at $50 \mathrm{~m}$ at night; a second specimen (41 mm ML) was taken in an open net at 585-0 $\mathrm{m}$ during the day. All other large specimens available have been taken from the stomachs of large fishes and sperm whales (Clarke, 1966:214), so we have little precise information concerning their vertical distribution.

Three specimens of Tetronychoteuthis dussumieri were captured off Bermuda; one $(21 \mathrm{~mm}$ ML) in a closing net at $350 \mathrm{~m}$ during the day, two (44 $\mathrm{mm}$ and $100 \mathrm{~mm} \mathrm{ML}$ ) in Engel trawls at night at $1000-0$ and $100-0 \mathrm{~m}$, respectively. In the eastern Atlantic seven specimens (36-166 mm ML) were captured in Engel trawls at night at $100-325 \mathrm{~m}$, four (31-159 mm ML) were taken at $600-800 \mathrm{~m}$ and one (64 mm ML) at $1800-0 \mathrm{~m}$.

Sixteen specimens of Pholidoteuthis adami (all greater than $250 \mathrm{~mm} \mathrm{ML}$ ) are available from the Gulf of Mexico, Caribbean Sea, and northeastern South American waters. All captures were made during the day in bottom trawls from $360-925 \mathrm{~m}$ (greatest number of captures $625-750 \mathrm{~m}$ ). No nighttime trawl captures are known so possibly this species leaves the near-bottom waters and disperses into middepths at night. Voss (1956:132) records the species from $85-870 \mathrm{~m}$ in the Gulf of Mexico; all captures were made with bottom trawls. Remains of $P$. boschmai were taken from stomachs of the shark Centroscymnus coelolepis captured on bottom-set long lines set at 998-1102 $\mathrm{m}, 1246 \mathrm{~m}, 1259 \mathrm{~m}, 1260 \mathrm{~m}$, and $1472 \mathrm{~m}$ (Clarke and Merrett, 1972).

\section{JOUBINITEUTHIDAE}

FICURE 27: BAR 15

The Joubiniteuthidae consists only of Joubiniteuthis portieri which is known from a few specimens. Captures were made in open nets that fished at $800-900 \mathrm{~m}$ and $2500 \mathrm{~m}$ during the day; $2000 \mathrm{~m}$ at night; and at $330 \mathrm{~m}, 350 \mathrm{~m}, 500 \mathrm{~m}$, and $3500 \mathrm{~m}$ at unknown times, although the first three are probably night captures (Young and Roper, 1969b). A large specimen was taken at night in an Engel trawl in the South Atlantic at 1900-0 m.

\section{CHIROTEUTHIDAE}

Figures 14-16, 29: BARS 3-7

The Chiroteuthidae consists of three genera; Chiroteuthis, Chiropsis, and Valbyteuthis. Information on the vertical distribution of some species of Chiroteuthis and Valbyteuthis is available, but the distribution of the monotypic Chiropsis is unknown, since only a single specimen of C. mega has been taken.

Members of the Chiroteuthidae generally have very distinctive larval stages that may attain a relatively large size before metamorphosis.

Larvae of Chiroteuthis calyx compose the bulk of the 136 specimens of this species captured off California. Metamorphosis to the subadult stage takes place when the larva attains a mantle length of $50-60 \mathrm{~mm}$. The vertical distribution of the larvae (Figure 14) presented here is based almost exclusively on specimens larger than $20 \mathrm{~mm}$ ML. Generally the youngest specimens live in the upper $100 \mathrm{~m}$, and as they grow they gradually descend to greater depths. In the upper $100 \mathrm{~m}$ larvae in the 20-30 mm ML size category are most abundant. At $300-400 \mathrm{~m}$ the $30-50 \mathrm{~mm}$ ML size range predominates, while at $500-700 \mathrm{~m}$ the $40-60 \mathrm{~mm}$ ML size category predominates. Specimens taken below $700 \mathrm{~m}$ probably are contaminants. 
The day-night distribution seems to indicate some larval vertical migration. Specimens were captured in the upper $100 \mathrm{~m}$ only at night. In successive (deeper) depth zones, the larger-sized specimens were captured predominantly at night and smaller specimens during the day. This indicates that at night, specimens probably shift upward from their slightly deeper daytime levels.

The subadult population (Figure 15) appears to occupy a zone between $500 \mathrm{~m}$ and $800 \mathrm{~m}$ during the daytime. Within this zone 14 specimens were captured; no subadults were taken above $500 \mathrm{~m}$. Two additional specimens, probably contaminants, were taken between $1000 \mathrm{~m}$ and $1100 \mathrm{~m}$. The 500 $800 \mathrm{~m}$ zone is approximately the level at which the largest larvae are found.

The vertical distribution of the nighttime population of subadult $C$. calyx is uncertain since only four specimens were captured. One specimen each was captured in 0-100 m, 200-300 m, 300$400 \mathrm{~m}$, and $400-500 \mathrm{~m}$. These captures occurred above the level of the daytime population. The

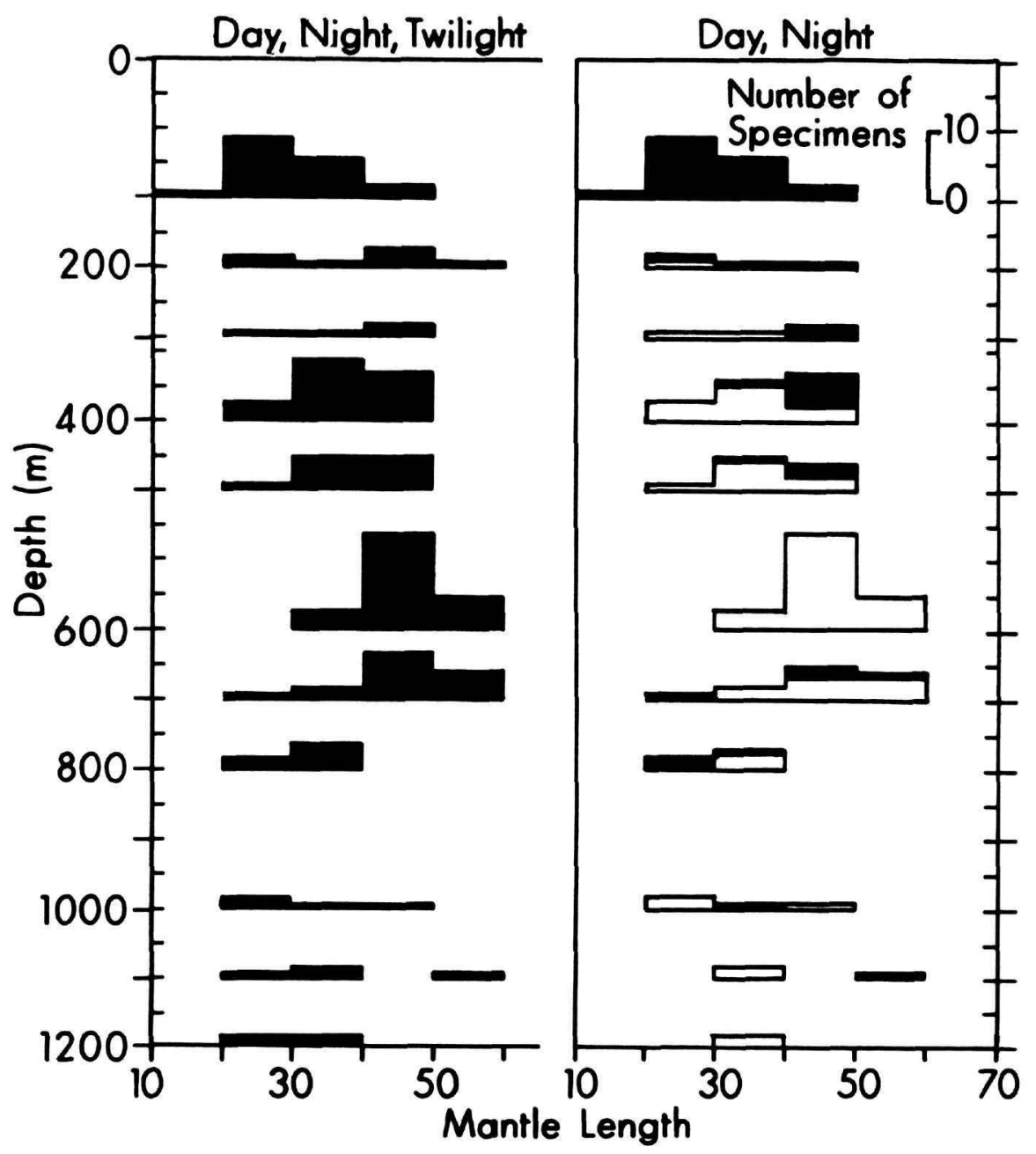

FIGURE 14.-Vertical distribution of the larvae of Chiroteuthis calyx off southern California. (Day, Night, Twilight: black bar $=$ total captures; Day, Night: black bar $=$ night captures, white bar $=$ day captures.) 
scanty data indicate that a migration or spreading out may occur at night. This interpretation is supported by a few captures from other areas.

Nighttime captures of two subadult Chiroteuthis sp. at 167-0 m were made off Bermuda and one subadult Chiroteuthis sp. was captured at $150-0 \mathrm{~m}$ off Hawaii. One subadult $C$. veranyi was taken in a closing trawl in the Mediterranean at $400 \mathrm{~m}$ at night. Three larval Chiroteuthis sp. (40-45 mm ML) were captured in a closing net during the day off Hawaii between $600 \mathrm{~m}$ and $660 \mathrm{~m}$.

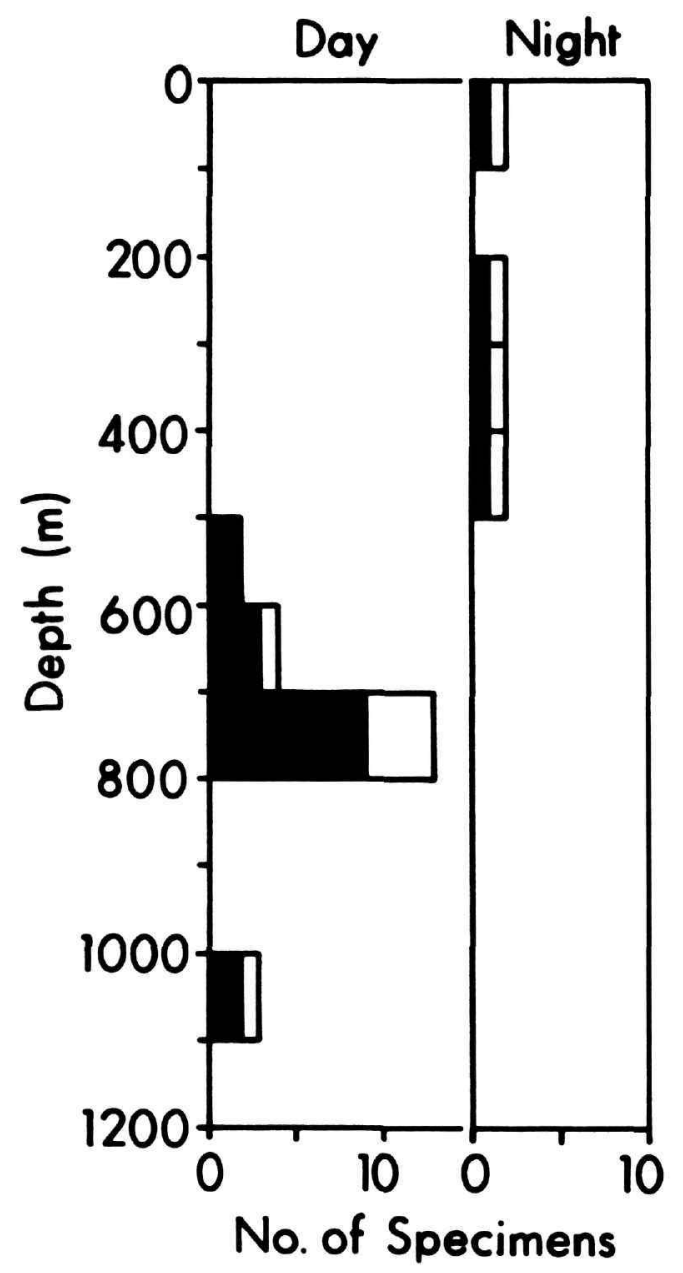

FIGURE 15.-Vertical distribution of subadults of Chiroteuthis calyx off southern California. (Black bar $=$ number of specimens captured; white bar $=$ correction factor.)

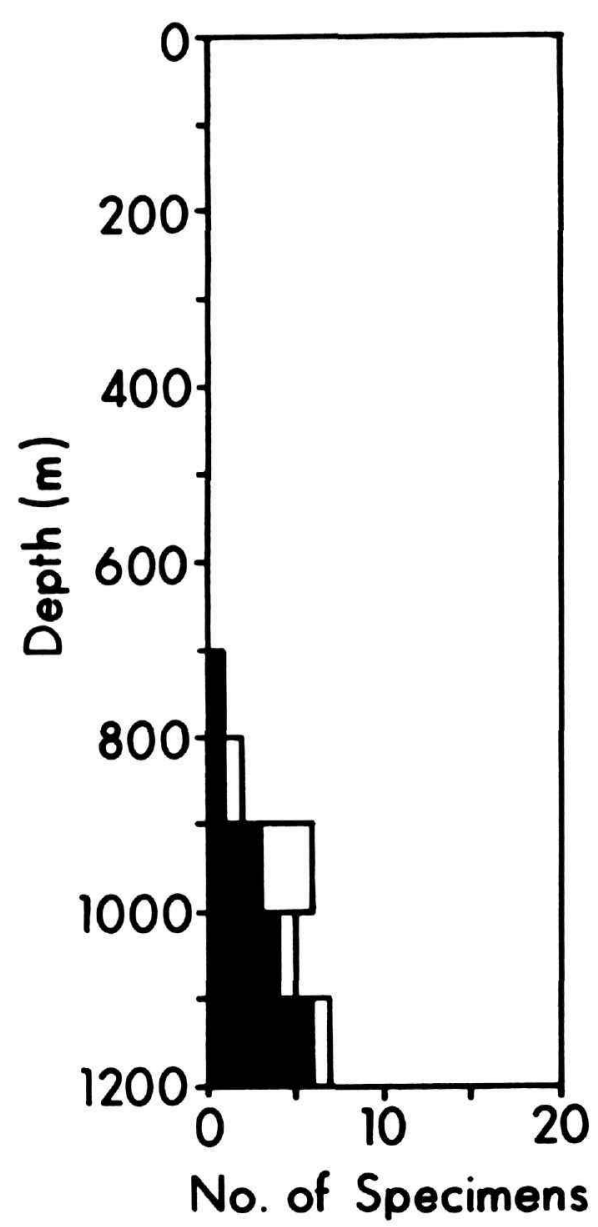

FIGURE 16.-Vertical distribution of Valbyteuthis oligobessa off southern California. (Black bar $=$ number of specimens captured; white bar = correction factor.)

The records for other species of Chiroteuthis are too few and too inconclusive to provide information on their vertical distributions.

Eighteen specimens of Valbyteuthis oligobessa were taken off California in 15 different open net tows (Figure 16). No specimens were taken in the upper $700 \mathrm{~m}$. A single specimen was taken at 700 $800 \mathrm{~m}$, one at $800-900 \mathrm{~m}$, three at $900-1000 \mathrm{~m}$, four at $1000-1100 \mathrm{~m}$, and six at $1100-1200 \mathrm{~m}$. The shallowest capture is the smallest specimen $(23 \mathrm{~mm}$ ML). The lower limit of distribution undoubtedly lies deeper than $1200 \mathrm{~m}$, beyond the range of the sampling program. Valbyteuthis is one of the 
deepest living cephalopods taken off California. There is no difference between daytime and nighttime distributions.

Data available on several other species of Valbyteuthis also indicate a deep-living habit (Roper and Young, 1967). Specimens larger than $20 \mathrm{~mm}$ ML were taken in open nets that fished at (in meters): 530, 683, 1000, 1162, 1250 (2 stations), 1500 (3 stations), 1830, and 2635. Two specimens ( $35 \mathrm{~mm}$ and $50 \mathrm{~mm} \mathrm{ML}$ ) were taken in closing nets off Hawaii at $875-1220 \mathrm{~m}$ during the day and $780-955 \mathrm{~m}$ at night. Four specimens $(22-45 \mathrm{~mm}$ ML). were captured in open nets that fished between $800 \mathrm{~m}$ and $900 \mathrm{~m}$ during the day and 700 and $800 \mathrm{~m}$ during the night.

In summary, the evidence suggests that some species of Chiroteuthis exhibit at least limited diel vertical migration. This is rather unexpected since they have small, weakly muscled mantles. It appears that the larvae of $C$. calyx at least, descend into deeper water as they increase in size until, by the time of metamorphosis, they have reached the depth of the subadult distribution.

Species of Valbyteuthis appear to be among the deepest living of all pelagic squid and apparently exhibit no diel vertical migration.

\section{MASTIGOTEUTHIDAE}

FIGURES 17, 29: BARS 8-11

The family Mastigoteuthidae consists of two genera. Echinoteuthis is recorded from only a few specimens and little is known of its distribution. Mastigoteuthis is a speciose genus, but meaningful data on vertical distributions are available for only a few species.

Mastigoteuthis pyrodes from California is represented by 27 specimens (Figure 17). Of the eight specimens captured during the daytime, none were taken above $600 \mathrm{~m}$; two were captured in $600-700 \mathrm{~m}$, five in $800-900 \mathrm{~m}$, and one in $1000-$ $1100 \mathrm{~m}$. Thirteen specimens are recorded as twilight captures. Many of these captures undoubtedly occurred during daytime in trawls that extended into the twilight period. If these data are considered in conjunction with daytime captures, it appears that the upper limit of the daytime distribution is around $600 \mathrm{~m}$. The lower limit is uncertain.
Of the five specimens captured at night; two were taken at $300-400 \mathrm{~m}$, one at $400-500 \mathrm{~m}$, and two at $600-700 \mathrm{~m}$. Some upward movement during the night may occur, but the data are too meager to allow a definitive statement.

Fifteen specimens of $M$. hjorti have been captured off Bermuda. Closing net captures were made at night at $450 \mathrm{~m} \mathrm{(27} \mathrm{mm} \mathrm{and} 28 \mathrm{~mm} \mathrm{ML})$ and $510 \mathrm{~m}$ (30 mm ML). Open net nighttime captures were as follows; four specimens (29-37 mm ML) at $450-0 \mathrm{~m}$, three (32-155 $\mathrm{mm} \mathrm{ML})$ at $750-0 \mathrm{~m}$, and two $(84 \mathrm{~mm}$ and $181 \mathrm{~mm} \mathrm{ML})$ at $760-0 \mathrm{~m}$. Open net daytime captures of three specimens (27-115 mm ML) were made at 800-0 m, 950-0 $\mathrm{m}$, and $1025-0 \mathrm{~m}$.

Off Hawaii Mastigoteuthis sp. has been taken in closing nets at 700-875 $\mathrm{m}$ during the day (two specimens) and at night two specimens were cap-

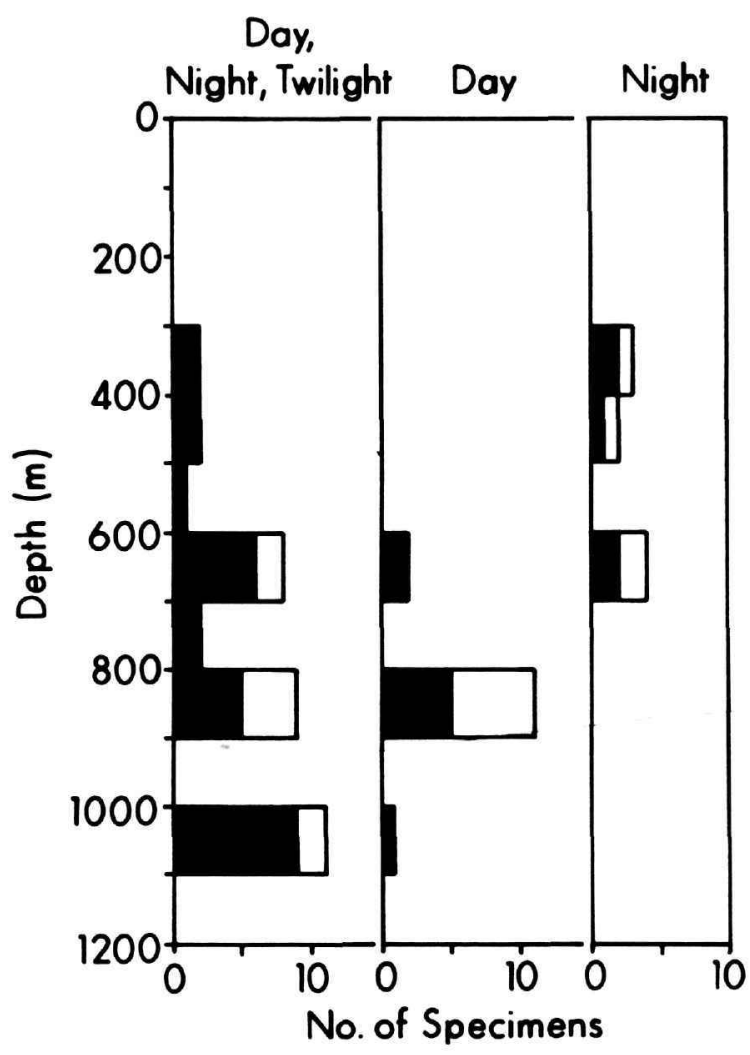

Figure 17.- Vertical distribution of Mastigoteuthis pyrodes off southern California. (Black bar $=$ number of specimens captured; white bar $=$ correction factor.) 
tured from $260-325 \mathrm{~m}$ and two others from 690 $770 \mathrm{~m}$ in closing nets. Five specimens $(24-55 \mathrm{~mm}$ ML) have been taken in open nets that fished from $670-850 \mathrm{~m}$ during the day. Two specimens of $M$. famelica were taken during the day, probably at $810 \mathrm{~m}$ in a closing net that fished from $700-925 \mathrm{~m}$. Eleven additional specimens $(25-41$ $\mathrm{mm}$ ML) were taken during the day in open nets between 700 and $800 \mathrm{~m}$ and single specimens were taken at $600-0$ and $1100-0 \mathrm{~m}$. A single specimen (37 mm ML) was captured in an open net at night at $375-0 \mathrm{~m}$.

It appears from the species examined that members of this genus are deep-living animals with the upper limits of daytime distribution probably at $600-700 \mathrm{~m}$ depending on the locality. At night the captures suggest that while some individuals remain at the daytime depths, others spread upward into the $200-700 \mathrm{~m}$ zone.

\section{PROMACHOTEUTHIDAE}

Figure 29: bar 12

The Promachoteuthidae has two known species in the single genus Promachoteuthis. The species $P$. megaptera is known from a single mutilated specimen taken by the CHALLENGER in an open bottom trawl that fished at $2440 \mathrm{~m}$ in the north Pacific. Two specimens of Promachoteuthis from Antarctic and southern Pacific waters were taken in open midwater trawls at $1391-0 \mathrm{~m}(10.5 \mathrm{~mm}$ $\mathrm{ML}$ ) and 1830-0 m (17 mm ML), respectively. Two specimens (greater than $25 \mathrm{~mm}$ ML) were taken in open Engel trawls in the south Atlantic at $1550-0 \mathrm{~m}$ and $1900-0 \mathrm{~m}$ at night. Based on the anatomical features of this species, Roper and Young (1968:213) suggested that it is a deep-sea species; indeed, it is probably one, of the deepest living of all squids.

\section{BATOTEUTHIDAE}

Figure 29: BAR 13

The Batoteuthidae is monotypic, known from only a few specimens (Young and Roper, 1968). Data on depths of capture in open nets are insufficient to verify vertical range; one larva $(30 \mathrm{~mm}$ ML) was taken at $366 \mathrm{~m}$ during the day and juve- niles and adults (51,90, and $95 \mathrm{~mm} \mathrm{ML}$ ) were taken at $1257 \mathrm{~m}, 1866 \mathrm{~m}$, and $2525 \mathrm{~m}$ during the night.

\section{GRIMALDITEUTHIDAE}

FIGURE 27: BAR 16

The Grimalditeuthidae is represented only by Grimalditeuthis bomplandii. The few previous records provide inadequate information on the vertical distribution of the species because depths of capture range from the surface to $2600 \mathrm{~m}$. In the Atlantic four specimens (greater than $46 \mathrm{~mm}$ ML) have been taken at night in open nets at $1275-0 \mathrm{~m}, 1300-0 \mathrm{~m}, 1690-0 \mathrm{~m}$, and $2100-0 \mathrm{~m}$. Off Hawaii this species has been taken at 750-0 m (58 mm ML) and 1435-0 m (97 mm ML) at night, and at $1150-0 \mathrm{~m}(80 \mathrm{~mm} \mathrm{ML})$ during the day. We suspect that $G$. bomplandii is a deepliving species.

\section{CRANCHIIDAE}

Figures 18-20, 30: BARS 1-9

The Cranchiidae is a highly diversified group that contains numerous genera and species. The family is so diverse and so poorly known that we shall make no attempt to survey the distributional records of all the genera. We shall discuss only the species for which we have accumulated direct information.

Galiteuthis phyllura off California is represented by 182 specimens (Figure 18). This species undergoes a metamorphosis at about $60 \mathrm{~mm}$ ML. The larvae exhibit ontogenetic descent whereby increasingly larger larvae occupy successively greater depths. In the upper $100 \mathrm{~m}$ larvae from 1-10 mm ML (mean 7.5 mm ML) predominate; between $100-300 \mathrm{~m}$ the $10-30 \mathrm{~mm}$ ML size range (mean $23.4 \mathrm{~mm} \mathrm{ML}$ ) predominates; at $300-500 \mathrm{~m}$ the $20-40 \mathrm{~mm}$ ML size (mean $28.1 \mathrm{~mm} \mathrm{ML}$ ) predominates; and at $500-600 \mathrm{~m}$ the $30-50 \mathrm{~mm}$ ML size (mean $33.3 \mathrm{~mm} \mathrm{ML}$ ) predominates. The mean values for most of these size groups would be larger if contamination of each depth zone from overlying zones were eliminated.

At approximately $60 \mathrm{~mm}$ ML larval development is complete and the animals descend to 900 
$\mathrm{m}$ or more as subadults (Figure 19). Twenty-one percent of the larval specimens less than $50 \mathrm{~mm}$ $\mathrm{ML}$, however, were taken in the 1000-1200 $\mathrm{m}$ zone and may descend prematurely, although contamination may be partly responsible for this peculiar pattern. No indication of vertical migration exists for specimens smaller than $55 \mathrm{~mm}$ ML.

During the daytime only a single specimen larger than $55 \mathrm{~mm}$ ML was taken in water shallower than $900 \mathrm{~m}$, one specimen was taken in 900-1000 $\mathrm{m}$, three in 1000-1100 $\mathrm{m}$, and seven in $1100-1200 \mathrm{~m}$. When twilight captures are considered as well, it seems clear that the bulk of the subadult population is located below $900 \mathrm{~m}$.

Only a small number of specimens was taken at night; three specimens were captured in the upper $200 \mathrm{~m}$, seven in $500-600 \mathrm{~m}$, and three in 1100 $1200 \mathrm{~m}$. The captures above $900 \mathrm{~m}$ indicate that some of the subadult population wander into the upper layers at night. Five of the seven specimens taken at 500-600 $\mathrm{m}$ at night are less than $100 \mathrm{~mm}$ ML; since this depth corresponds approximately to the maximum depth of larval occurrence, this may indicate that a tendency exists for some specimens to remain there after metamorphosis.

Off Hawaii, nine specimens (20-52 mm ML) of G. pacifica were taken in open nets that fished below $650 \mathrm{~m}$ (seven day captures and two night captures). Four additional specimens (25-258 $\mathrm{mm}$ ML) were taken during the day in closing nets between $650-800 \mathrm{~m}$, and another specimen (42 $\mathrm{mm}$ ML) was captured in a closing net probably at $550 \mathrm{~m}$ (500-560 $\mathrm{m}$ range) during the day. In spite of the single record at $550 \mathrm{~m}, \mathrm{G}$. pacifica appears generally to occupy depths below $600 \mathrm{~m}$ during both day and night. This species undergoes meta-

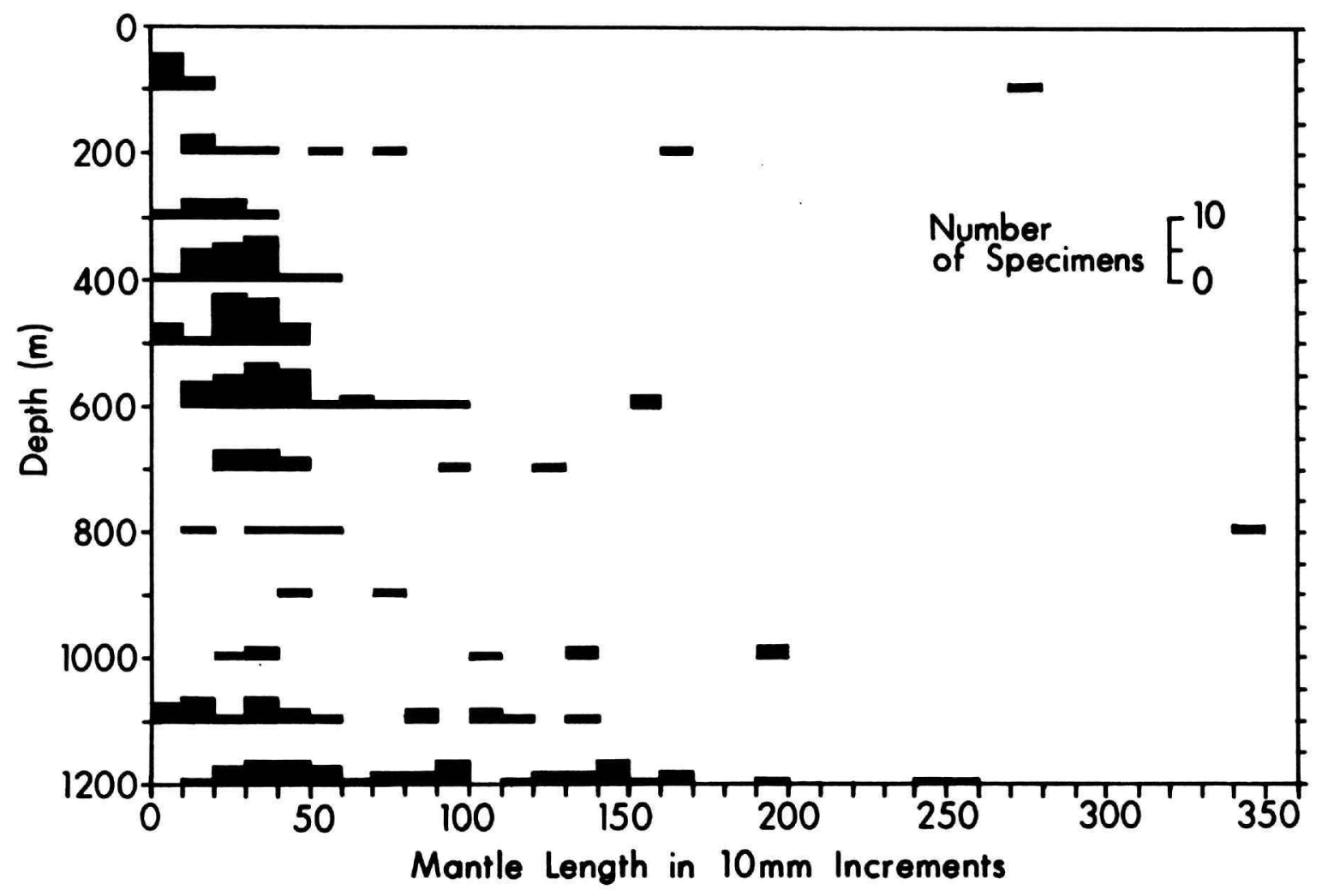

Figure 18.-Vertical distribution with respect to size-groups of Galiteuthis phyllura off southern California. (Black bar $=$ number of specimens captured.) 
morphosis at about $40-45 \mathrm{~mm} \mathrm{ML}$. Data are insufficient to show the existence of ontogentic descent.

Galiteuthis glacialis is restricted primarily to Circumpolar Deep Water in Antarctic waters (McSweeny, 1971:104). Based on open net data, McSweeny (1971) concluded that the vertical range of the species extends from $200 \mathrm{~m}$ to about $1400-1500 \mathrm{~m}$; the bulk of the population lives between 600 and $1000 \mathrm{~m}$. An indication of ontogenetic descent exists, since the mean capture depths for successively larger $10 \mathrm{~mm}$ size groups increase for animals of 20-90 mm ML. McSweeny also suggested that a diel vertical migration occurs; maximum daytime captures occur at 800-1000 m while maximum nighttime captures occur at 400$600 \mathrm{~m}$. McSweeny's data indicate that, rather than a well-defined migration, the animals disperse at night into a broader range of depths since nighttime captures are relatively high between 200 and $1000 \mathrm{~m}$.

In the California study 102 specimens of Helicocranchia pfefferi (10-70 $\mathrm{mm} \mathrm{ML}$ ) were used to plot vertical distribution (Figure 20). The specimens captured both during the day and night with open nets are well intermixed at all depth levels. No specimens were taken in the upper 100 $\mathrm{m}, 4$ percent were captured between $100-200 \mathrm{~m}$, 21 percent in $200-300 \mathrm{~m}, 38$ percent in $300-400 \mathrm{~m}$, 11 percent in $400-500 \mathrm{~m}, 12$ percent in $500-600 \mathrm{~m}, 3$ percent in $600-700 \mathrm{~m}, 8$ percent in $700-800 \mathrm{~m}$, and 4 percent below $800 \mathrm{~m}$. The bulk of the captures (59 percent) occurs in the zone between 200 and $400 \mathrm{~m}$. Eighty-seven percent of the specimens captured in this zone are 10-40 mm ML. Although only a small number of specimens (20)

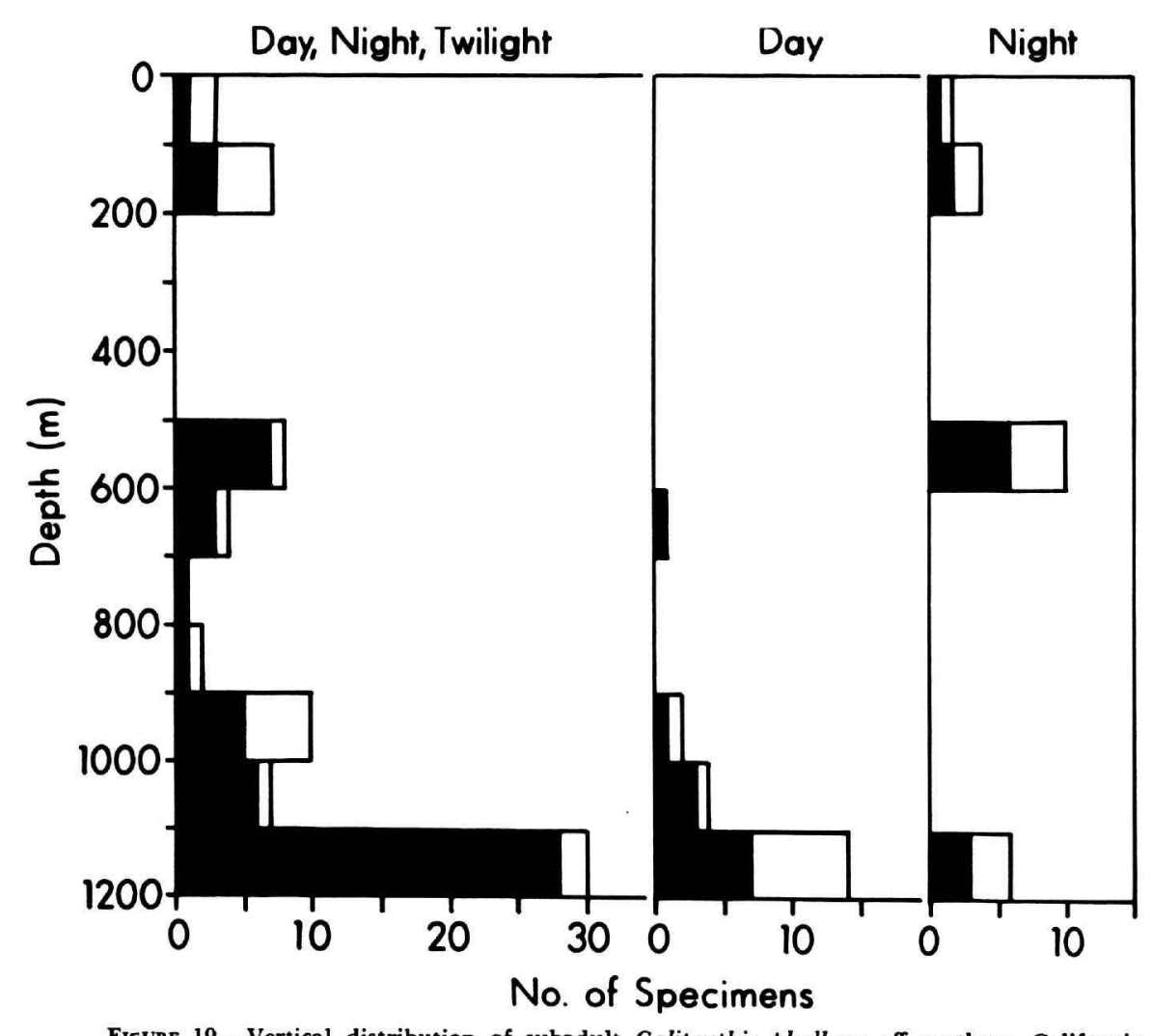

FigUre 19.-Vertical distribution of subadult Galiteuthis phyllura off southern California. (Black bar = number of specimens captured; white bar = correction factor.) 
was captured in the 400-600 m zone, 65 percent of these were over $40 \mathrm{~mm}$ ML. The data suggest that larger animals (i.e., over $40 \mathrm{~mm} \mathrm{ML}$ ) live in deeper water. A break in distribution lies at $600 \mathrm{~m}$ which may be the bottom of the vertical range of H. pfefferi. The deeper captures presumably are contaminants. No diel vertical migration occurs.

Records for seven larval specimens of Taonius pavo are available from Bermuda and Hawaii. Off Bermuda three specimens (35-43 mm ML) were captured in closing nets between $610-690 \mathrm{~m}$ during the day. Off Hawaii, four daytime captures $(60-$ $115 \mathrm{~mm} \mathrm{ML}$ ) were made in closing nets between 600 and $800 \mathrm{~m}$.

Two specimens of Bathothauma lyromma (23 and $33 \mathrm{~mm} \mathrm{ML)}$ were captured off Bermuda at $520 \mathrm{~m}$ at night in closing nets. Off Hawaii one specimen ( $80 \mathrm{~mm} \mathrm{ML}$ ) was taken in a closing net at night at 700-730 $\mathrm{m}$ and a mature female (100 $\mathrm{mm} \mathrm{ML}$ ) was captured in a closing net at 1015$1300 \mathrm{~m}$ during the day.

Leachia sp. off Bermuda is represented in our collections by 309 specimens that range from 4$50 \mathrm{~mm}$ ML. During the day 159 specimens (4-28 $\mathrm{mm} \mathrm{ML}$ ) were taken at $50 \mathrm{~m}$ and 12 specimens (25-50 mm ML) were taken at $60 \mathrm{~m}$. At night 93 specimens (7-29 mm ML) were taken at $50 \mathrm{~m}$; 36 specimens (5-24 mm ML) were captured at $100 \mathrm{~m}$, and nine specimens $(26-48 \mathrm{~mm} \mathrm{ML})$ were taken at $135-230 \mathrm{~m}$. It is worth noting that most of the large specimens taken during the daytime were the deepest captures. No evidence of diel vertical movement exists.

Off Baja California, a specimen of Leachia dislocata (100 mm ML) was dipnetted at the surface at night.

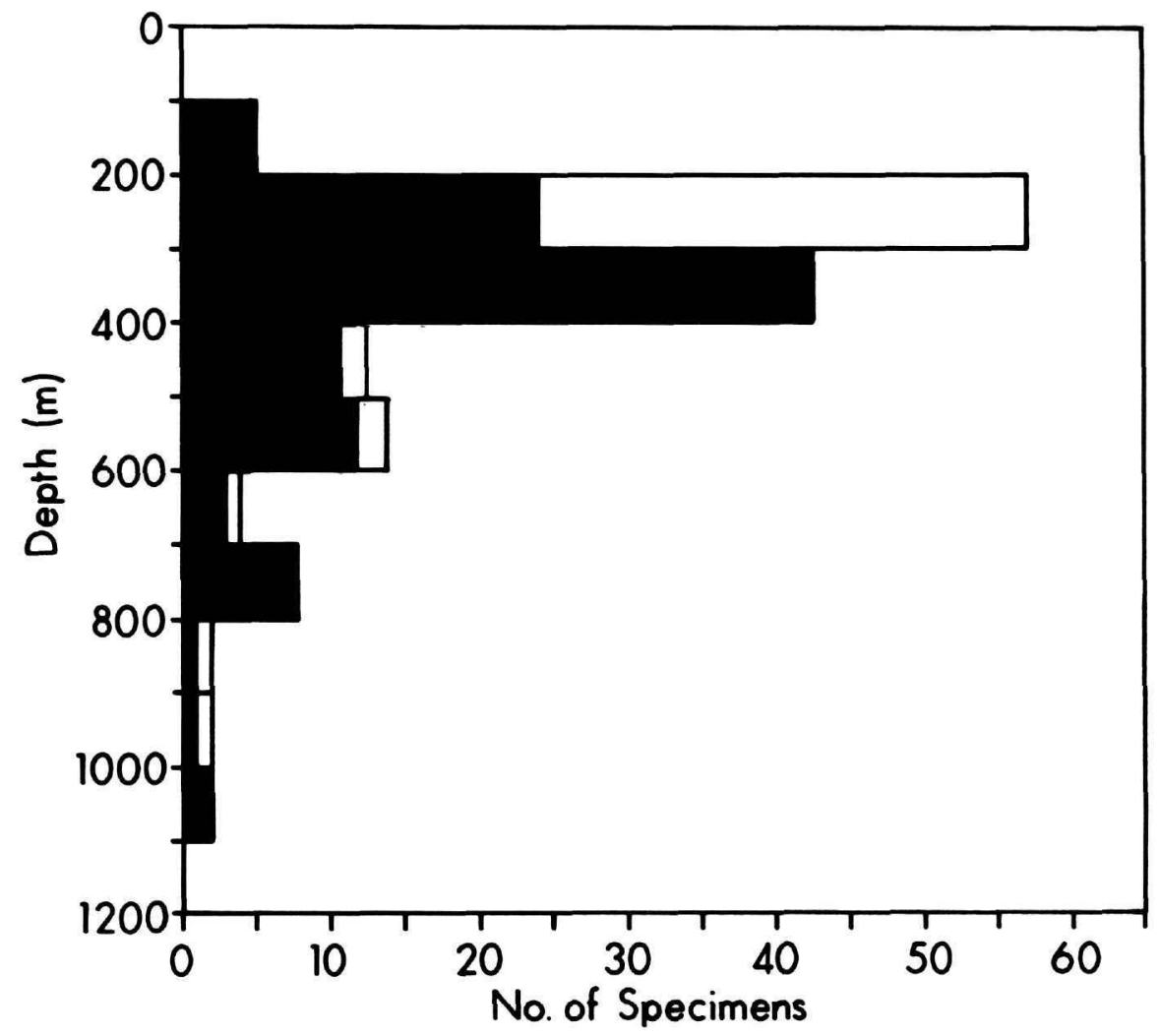

FIGURE 20.-Vertical distribution of Helicocranchia pfefferi off southern California. (Black bar $=$ number of specimens captured; white bar $=$ correction factor.) 
Five specimens of Phasmatopsis oceanica (17$29 \mathrm{~mm}$ ML) were taken in closing nets off Bermuda during the day between $90 \mathrm{~m}$ and $200 \mathrm{~m}$ and three specimens (19-27 mm ML) were captured at night from $50-175 \mathrm{~m}$. Off Hawaii, 97 specimens (8-55 mm ML; one at $130 \mathrm{~mm} \mathrm{ML)} \mathrm{of} \mathrm{P.} \mathrm{fisheri}$ were taken at night from $200-0 \mathrm{~m}$, and five specimens, presumably contaminants, from $800-0 \mathrm{~m}$. Daytime captures for this species are inconclusive.

Off Hawaii, 16 specimens of Liocranchia valdiviae have been captured in closing nets. Apparently $10-20 \mathrm{~mm} M L$ is the size range at which the larvae begin to assume the adult habitat. Eleven specimens less than $20 \mathrm{~mm}$ ML have been taken at scattered depths between $175 \mathrm{~m}$ and $750 \mathrm{~m}$. Five specimens from 21-42 mm ML have been taken in closing nets from $650 \mathrm{~m}$ to about $1050 \mathrm{~m}$. Sixtyeight specimens were taken in open nets of which 33 specimens larger than $21 \mathrm{~mm} \mathrm{ML}$ were captured between $700 \mathrm{~m}$ and $1200 \mathrm{~m}$. Twenty of these came from $700-800 \mathrm{~m}$, five from $800-900 \mathrm{~m}$, six from $900-1000 \mathrm{~m}$, and two from $1000-1200 \mathrm{~m}$. Day and night captures are intermixed for all specimens larger than $21 \mathrm{~mm}$ ML.

The species we have examined in the Cranchiidae exhibit several different patterns of vertical distribution. The juveniles, at least, of some species (e.g., Leachia, Phasmatopsis) live in near-surface waters. Some (e.g., Helicocranchia) occupy intermediate depths. Most species, however, live in deep water below 600-700 m (e.g., Liocranchia, Galiteuthis, Taonius, Bathothauma). At present no species has been shown to exhibit strong vertical migration. One distributional pattern appears to be prominant in the family: Many species exhibit ontogenetic descent, that is, in larval and juvenile stages, larger specimens inhabit progressively deeper waters. Where known, adults and subadults occupy the deepest waters.

\section{Order VAMPYROMORPHA}

\section{VAMPYROTEUTHIDAE}

Figures 21, 31: BAR 1

The vertical distribution of Vampyroteuthis infernalis, the only species in the order Vampyromorpha, has been extensively investigated by Pick- ford $(1946,1949)$. She $(1946: 25)$ states that the majority of specimens are found in water that has a salinity between $34.7 \%$ and $34.9 \%$ (maximum range $34.5-35.5 \%$ ), an oxygen content between $1.00 \mathrm{ml} / \mathrm{L}$ and $3.99 \mathrm{ml} / \mathrm{L}$, a density (sigma-t) between 27.4 and 27.8 (maximum range 27.0-27.9), a temperature between $2.0^{\circ}$ and $6.0^{\circ} \mathrm{C}$ (maximum range $\left.1.73^{\circ}-15.46^{\circ} \mathrm{C}\right)$. The species is most abundant between $1500 \mathrm{~m}$ and $2500 \mathrm{~m}$ in the Pacific Ocean and 1000-2000 $\mathrm{m}$ in the Atlantic Ocean.

Vampyroteuthis infernalis was the third most abundant species in the California study. Three hundred and eighty-five specimens were captured ranging in size from $8 \mathrm{~mm}$ to $110 \mathrm{~mm} \mathrm{ML}$ (Figure 21). The daytime and nighttime captures intermingle at all depths, indicating that no vertical migration occurs. No specimens were taken in the upper $100 \mathrm{~m}$, and only 2 percent were taken between $100 \mathrm{~m}$ and $400 \mathrm{~m}$. This species is susceptible to entanglement in trawl nets, and very likely many of the records above $400 \mathrm{~m}$ represent contamination of this type from preceeding deeper trawls. Six percent of the specimens were captured between $400 \mathrm{~m}$ and $600 \mathrm{~m}$, part of which may represent contamination and part stragglers from the main population. Forty-five percent of the captures occurred between $600 \mathrm{~m}$ and $800 \mathrm{~m}$ with those between $700 \mathrm{~m}$ and $800 \mathrm{~m}$ accounting for 34 percent of the captures. The $800-900 \mathrm{~m}$ zone accounts for 8 percent of the specimens, the $900-1000 \mathrm{~m}$ zone 15 percent, the $1000-1100 \mathrm{~m}$ zone for 16 percent, and the 1100-1200 $\mathrm{m}$ zone 6 percent. When catch per trawling effort is considered, peaks occur in the distribution at $700-800 \mathrm{~m}$ and at $900-1000 \mathrm{~m}$. Sixty-five percent of the specimens with a mantle length less than $20 \mathrm{~mm}$ were captured deeper than $900 \mathrm{~m}$, while 76 percent of the specimens with a mantle length of $20 \mathrm{~mm}$ or larger occur shallower than $900 \mathrm{~m}$. This size is the point at which the larval fins begin to be resorbed. The larval forms, therefore, generally occupy a slightly deeper layer than the adults.

The upper limit of most of the captures is 600 $\mathrm{m}$, and the lower limit probably is $1100 \mathrm{~m}$ or 1200 $\mathrm{m}$. Even though the water off California between $1200 \mathrm{~m}$ and $2200 \mathrm{~m}$ (around the $2^{\circ} \mathrm{C}$ isotherm) would appear to be well suited to $V$. infernalis, according to previous studies, the species probably 


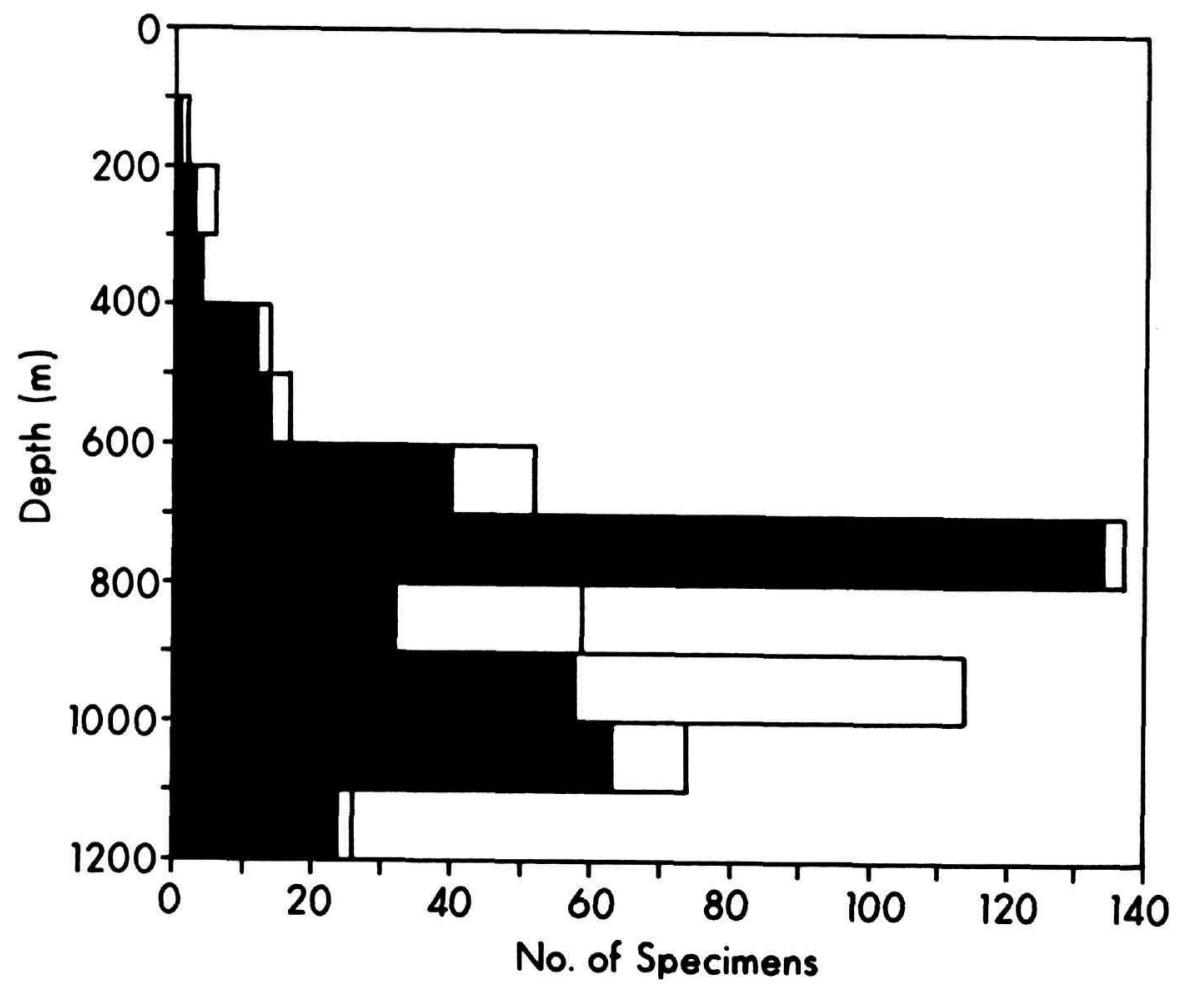

Figure 21.-Vertical distribution of Vampyroteuthis infernalis off southern California. (Black bar $=$ number of specimens captured; white bar $=$ correction factor.)

is absent or at least not abundant in this zone. The vertical distribution falls within a temperature range of approximately $3^{\circ}-6^{\circ} \mathrm{C}$, a salinity variation of $34.4 \%$ to slightly over $34.5 \%$, a density (sigma-t) range of 27.1-27.5, and oxygen values of 0.3-0.8 $\mathrm{ml} / \mathrm{L}$. These values extend the limits for the majority of previously recorded specimens, for all parameters except temperature. These limits, however, are so broad that other features may be equally or more important in controlling the distribution of this species.

Off Bermuda, 12 specimens of $V$. infernalis were captured between $950 \mathrm{~m}$ and $1500 \mathrm{~m}$ in open nets. In the south Atlantic 175 specimens (18-94 mm ML) of $V$. infernalis were taken in open Engel trawls at night; 115 specimens were taken at 1300 $2000 \mathrm{~m}$, with the large majority at 1800-2000 m (13 tows), and 10 were taken in five tows that fished between $500 \mathrm{~m}$ and $1000 \mathrm{~m}$. One tow captured 50 specimens at $640-0 \mathrm{~m}$.

\section{Order OCTOPODA}

Suborder CIRRATA

\section{CIRROTEUTHIDAE and STAUROTEUTHIDAE}

Figures 22, 31: Bars 10, 11

Species in these families are rare in collections, and the systematics are very confused; relatively little is known of their distributions. Recently Roper and Brundage (1972) reviewed the depth records in the literature and added information based on deep-sea photographs. They concluded that Cirroteuthis spp., and probably some of the other cirrates as well, are benthopelagic, living just above, but not on, the ocean bottom (Figure 22). Records for species of Cirroteuthis, Grimpoteuthis, and Stauroteuthis indicate that the group as a whole extends from about $350 \mathrm{~m}$ to $5300 \mathrm{~m}$. While a few species appear to live primarily shal- 

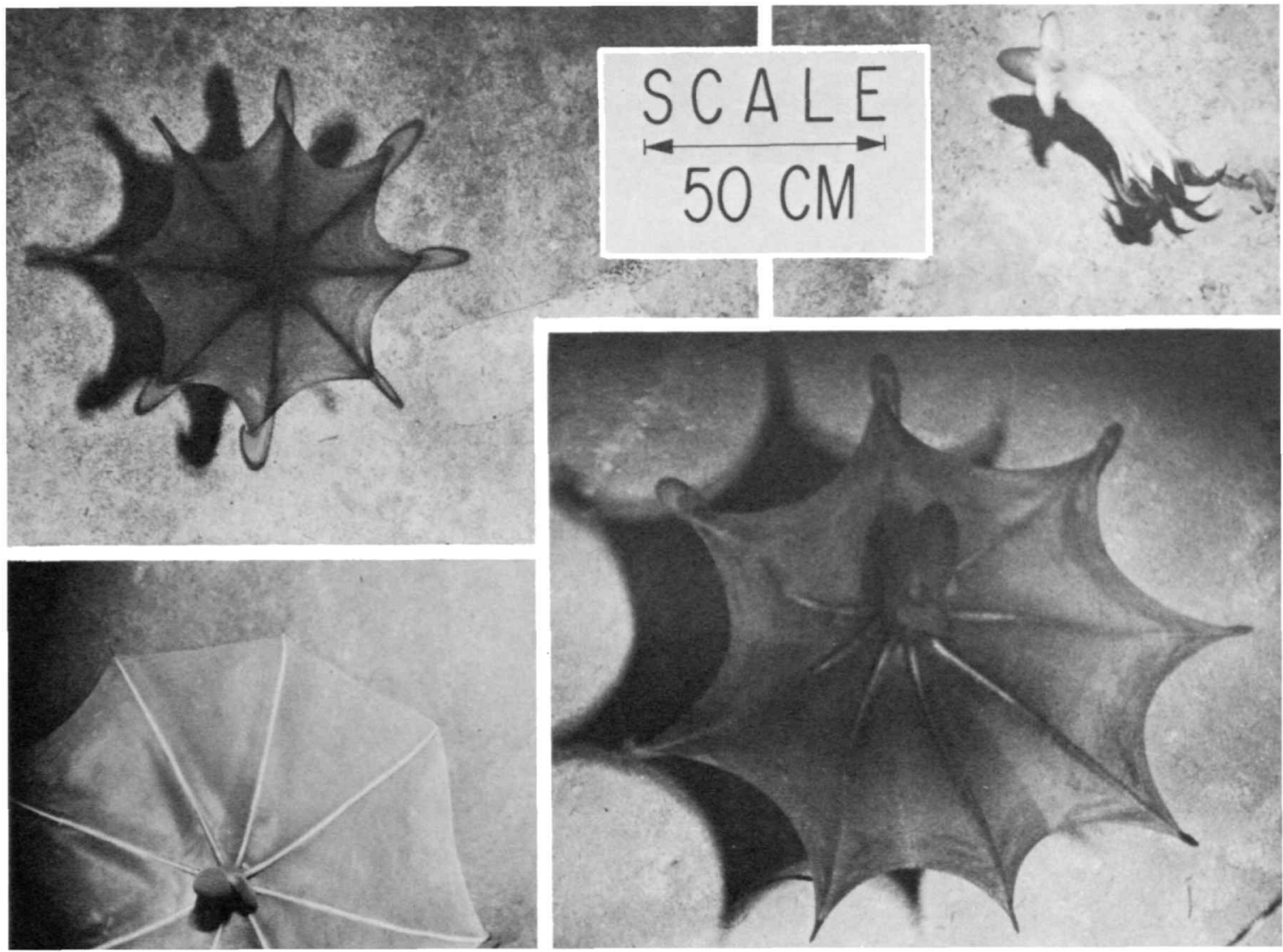

FigurE 22.-Cirrate octopods near ocean bottom in Virgin Islands Basin, 3600-3950 m. Scale approximate. (After Roper and Brundage, 1972.)

lower than $1000 \mathrm{~m}$, the large majority occur at depths in excess of $1000 \mathrm{~m}$ and many of these in excess of $2000 \mathrm{~m}$ (Robson, 1932:82-89). The photographic records of Roper and Brundage (1972) are concentrated in $3500-5200 \mathrm{~m}$.

Cirrothauma murrayi, known from only a few specimens, is pelagic (Roper and Brundage, 1972: 14) and has been taken in open midwater nets at the following depths: $1500 \mathrm{~m}, 2900 \mathrm{~m}$ (night), $3600 \mathrm{~m}$ (day), and $4050 \mathrm{~m}$ (night). Specimens of this species are very fragile and are blind. The clear indication of deep-living habitat provided by anatomical and trawl data is partially offset by the capture of a specimen at the surface through the ice in the Arctic Ocean; this may, however, be an example of polar emergence of the widely distributed species.

\section{OPISTHOTEUTHIDAE}

The several species in this monotypic family, represented by Opisthoteuthis, all appear to be benthic forms; they are weak swimmers and seldom leave the bottom (Pereyra, 1965:436). Depth records range from $125-2251 \mathrm{~m}$, but the great majority of captures come from 400-1000 m (see discussion in Roper and Brundage, 1972:16).

Pereyra (1965:430) reports that Opisthoteuthis californiana is distributed from $125-825 \mathrm{~m}$, the shallower captures occurring in the northern end 
of its range. In addition, males of $O$. californiana appear to occupy shallower depths than females and to move into shallower water during the summer.

\section{Suborder INCIRRATA}

\section{BOLITAENIDAE}

Figures 23, 31: Bars 2, 3

Thore (1949) monographed the family Bolitaenidae and treated the horizontal and vertical distribution based on open net captures of one of the most common species, Japetella diaphana. He

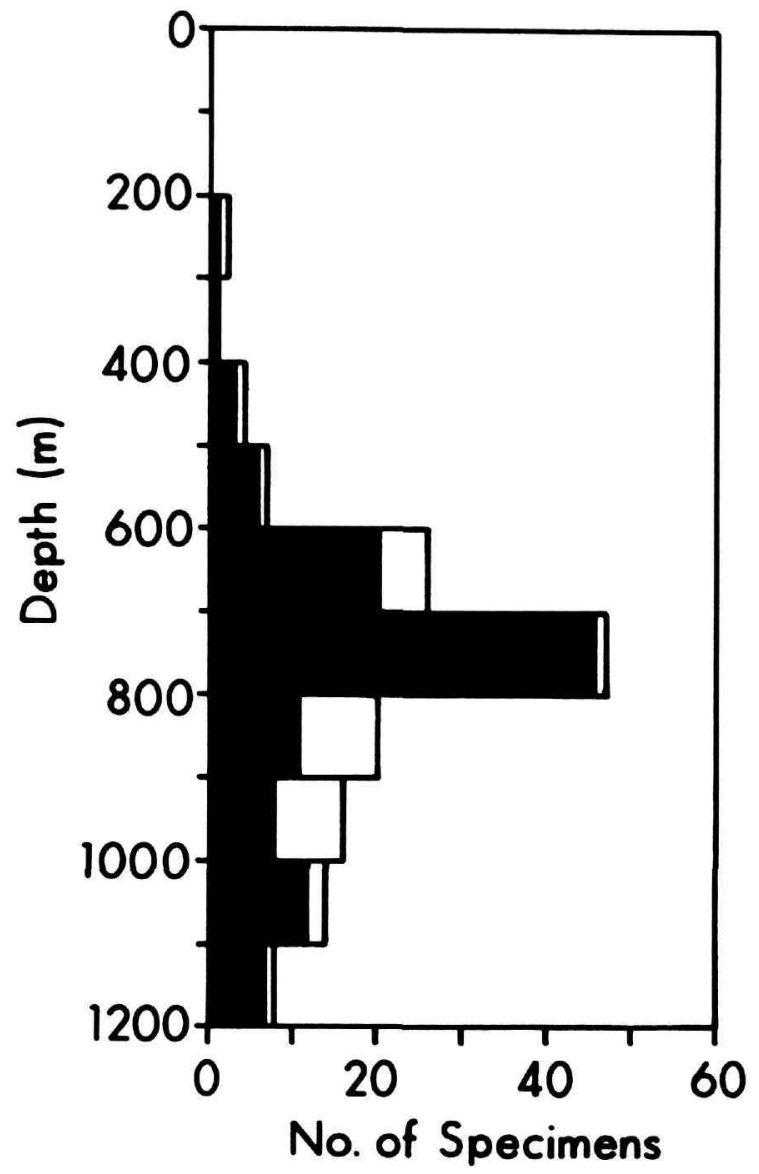

Figure 23.-Vertical distribution of Japetella sp. and $J$. heathi, off southern California. (Black bar $=$ number of specimens captured; white bar $=$ correction factor.) considered this species to be world-wide but latitudinally bounded by the $10^{\circ} \mathrm{C}$ isotherm at $200 \mathrm{~m}$. Thore's data on the vertical distribution of $J$. diaphana indicated that young specimens less than $25 \mathrm{~mm}$ ML live between $100 \mathrm{~m}$ and $330 \mathrm{~m}$, while larger specimens migrate to greater depths, with a lower limit between $3000 \mathrm{~m}$ and $4000 \mathrm{~m}$.

Two species of Japetella occur off southern California. Nearly all specimens are J. heathi; however, since it is impossible to separate the two species at small sizes, their distributions are considered together. The 115 specimens $(8-100 \mathrm{~mm}$ ML) captured in open nets were intermixed at all depths during the day and night (Figure 23).

No specimens were captured in the upper $200 \mathrm{~m}$, 10 percent between $200 \mathrm{~m}$ and $600 \mathrm{~m}, 57$ percent from $600-800 \mathrm{~m}$, and 33 percent from $800-1200 \mathrm{~m}$. All specimens captured shallower than $600 \mathrm{~m}$ were less than $20 \mathrm{~mm} \mathrm{ML}$ and were nighttime captures. Below $600 \mathrm{~m}, 74$ percent of the specimens less than $30 \mathrm{~mm} \mathrm{ML} \mathrm{occur} \mathrm{in} \mathrm{the} 600-800 \mathrm{~m}$ zone. This size category comprises over 80 percent of the total captures in the $600-800 \mathrm{~m}$ range. Specimens larger than $30 \mathrm{~mm} \mathrm{ML}$ are evenly distributed from 600-1200 m. Therefore, nearly all the younger specimens seem to occupy a rather restricted vertical zone between $600-800 \mathrm{~m}$, while the larger animals occur from $600 \mathrm{~m}$ to the depth limits of the sampling program and presumably occur in greater depths.

The genus Bolitaena consists of a single poorly known species, $B$. microcotyla. Off Hawaii a brooding female ( $35 \mathrm{~mm} \mathrm{ML)} \mathrm{was} \mathrm{taken} \mathrm{in} \mathrm{a}$ closing net between $830 \mathrm{~m}$ and $975 \mathrm{~m}$ during the day (Young, 1972b).

Thore (1949:62) suggests that Eledonella pygmaea has a distribution similar to that of Japetella diaphana.

\section{VITRELEDONELLIDAE}

FIGURE 31: BAR 4

According to Thore's (1949) data, specimens of Vitreledonella richardi less than $100 \mathrm{~mm} \mathrm{ML}$ occur in the upper $300 \mathrm{~m}$, while those larger than 100 $\mathrm{mm}$ ML occur below $1000 \mathrm{~m}$ with a peak concentration at 1000-1050 m. Off Hawaii one specimen (23 $\mathrm{mm} \mathrm{ML}$ ) of $V$. richardi was captured in a closing net during the day between $615 \mathrm{~m}$ and 
$690 \mathrm{~m}$. Off Bermuda four larval specimens less than $11 \mathrm{~mm} \mathrm{ML}$ were captured in closing nets during the night and twilight at depths of 200-300 m.

\section{AMPHITRETIDAE}

FIGURE 31: BAR 5

This monotypic family consists of only Amphitretus pelagicus. Based on five captures, Thore (1949:55) reported that small specimens $(20 \mathrm{~mm}$ ML and smaller) occur in the upper $133 \mathrm{~m}$. Data of adults are inconclusive. One specimen $(35 \mathrm{~mm}$ ML) was taken at night off Hawaii in a closing net at 240-260 $\mathrm{m}$.

In the South Atlantic five specimens of $A$. pelagicus were captured at night in Engel trawls: one (20 mm ML) at $300-0 \mathrm{~m}$, two ( $30 \mathrm{~mm}$ and 32 $\mathrm{mm} \mathrm{ML)} \mathrm{at} 600-0 \mathrm{~m}$ and $750-0 \mathrm{~m}$, and two (34 $\mathrm{mm}$ and $52 \mathrm{~mm} \mathrm{ML)}$ at $2000-0 \mathrm{~m}$.

\section{ALLOPOSIDAE}

FIGURE 31: BAR 6

The Alloposidae consists of a number of nominal species, all of which have been considered as synonyms of Alloposus mollis in the review by Thore (1949). The vertical distribution of $A$. mollis presents a perplexing problem, since specimens have been recorded from the surface to as deep as $3180 \mathrm{~m}$.

Thore (1949:71) reported that specimens from 7-400 mm ML, taken in open midwater nets, occurred from 0-333 m; specimens less than $80 \mathrm{~mm}$ ML were limited to the upper $33 \mathrm{~m}$. In general, captures of both large and small specimens are concentrated in the near-surface waters from open pelagic nets $(0-200 \mathrm{~m})$ and at around $450-1000 \mathrm{~m}$ from the bottom trawls (Thore, 1949:71; Robson, 1932:84; Verrill, 1882b:366). The National Marine Fisheries Service, Hawaii, has captured as many as 26 large specimens of $\boldsymbol{A}$. mollis in a single otter trawl that fished at $682 \mathrm{~m}$ (L. Burgess, per. comm.).

Thore (1949:72), concluded that the species is a cosmopolitan form that spends part of its life on the bottom and part in open water but always in association with landmasses.
The pelagic and benthic captures of this gelatinous octopod seem peculiar and require further investigation before we can gain an understanding of its vertical distribution.

\section{TREMOCTOPODIDAE}

Figure 31: BAR 8

The family is represented by Tremoctopus violaceus and possibly by $T$. lucifer Akimushkin, 1963. Tremoctopus violaceus is a pelagic cosmopolitan species in all warm and temperate waters of the world. Females attain a large size $(200 \mathrm{~mm}$ ML; Kramer, 1937), but males are much smaller (about 20-30 mm ML). Most specimens recorded in the literature are from the surface of nearsurface waters, with a few scattered to about $300 \mathrm{~m}$ (Robson, 1932:85).

Off Bermuda, a juvenile $T$. violaceus $(6 \mathrm{~mm}$ ML) was captured in a closing net at $100 \mathrm{~m}$ during the day, 10 juveniles (5-10 mm ML) were captured at the surface at night, and one juvenile was taken at $250 \mathrm{~m}$ at night.

\section{OCYTHOIDAE}

Figure 31: BAR 9

Ocythoe tuberculata, the sole species in the family, has been recorded from scattered oceanic localities (Robson, 1932:85; Berry, 1955:219), but nowhere does it seem to be abundant. Females attain a large size (up to about $300 \mathrm{~mm} \mathrm{ML}$ ), but males remain small (about $20 \mathrm{~mm} \mathrm{ML}$ ) and apparently live within pelagic salps in near-surface waters (Hardwick, 1970). The species is pelagic and seems to inhabit the near surface waters, but nothing more can be stated about its vertical distribution.

\section{ARGONAUTIDAE}

FIGURE 31: BAR 7

The several species of Argonauta, the sole genus in the family, are all open ocean dwellers that inhabit warm waters of the world (Robson, 1932:85). Many records in the literature indicate a surface and near-surface habitat. We have captured spawn- 
ing adult females (shell diameters greater than $200 \mathrm{~mm}$ ) at the surface at night in the Florida Current.

Four juvenile males (5-8 mm ML) of $A$. argo were captured in closing nets between $50 \mathrm{~m}$ and $200 \mathrm{~m}$ off Bermuda. In the Mediterranean Sea in closing nets, six juvenile males and females (5-13 $\mathrm{mm} \mathrm{ML}$ ) and one adult female (72 $\mathrm{mm} \mathrm{ML}$ ) of $A$. argo were captured at the surface at night and one juvenile female ( $6 \mathrm{~mm} \mathrm{ML}$ ) was captured at $155 \mathrm{~m}$ at night.

The species of Argonauta inhabit the surface and near-surface waters.

\section{Discussion}

A complete analysis of the vertical distribution of pelagic cephalopods should include information concerning physical and biological parameters that may regulate species distributions. Of particular importance are the roles of light, temperature, productivity, competition and predation in regulating species distributions. Also, the relationships of species distributions to vertical faunal zones should be considered. Unfortunately, knowledge concerning vertical distribution in cephalopods is rudimentary and we are restricted to a general discussion of approximate habitats and day-night differences in distribution.

The information presented here reveals a variety of patterns of vertical distribution in pelagic cephalopods. The types of patterns presented below are not all mutually exclusive; some species may exhibit a combination of patterns. All patterns are not necessarily sharply delimited.

Near Surface Dwellers.-A number of species are found at or near the surface of the ocean throughout the diurnal cycle. Apparently only a

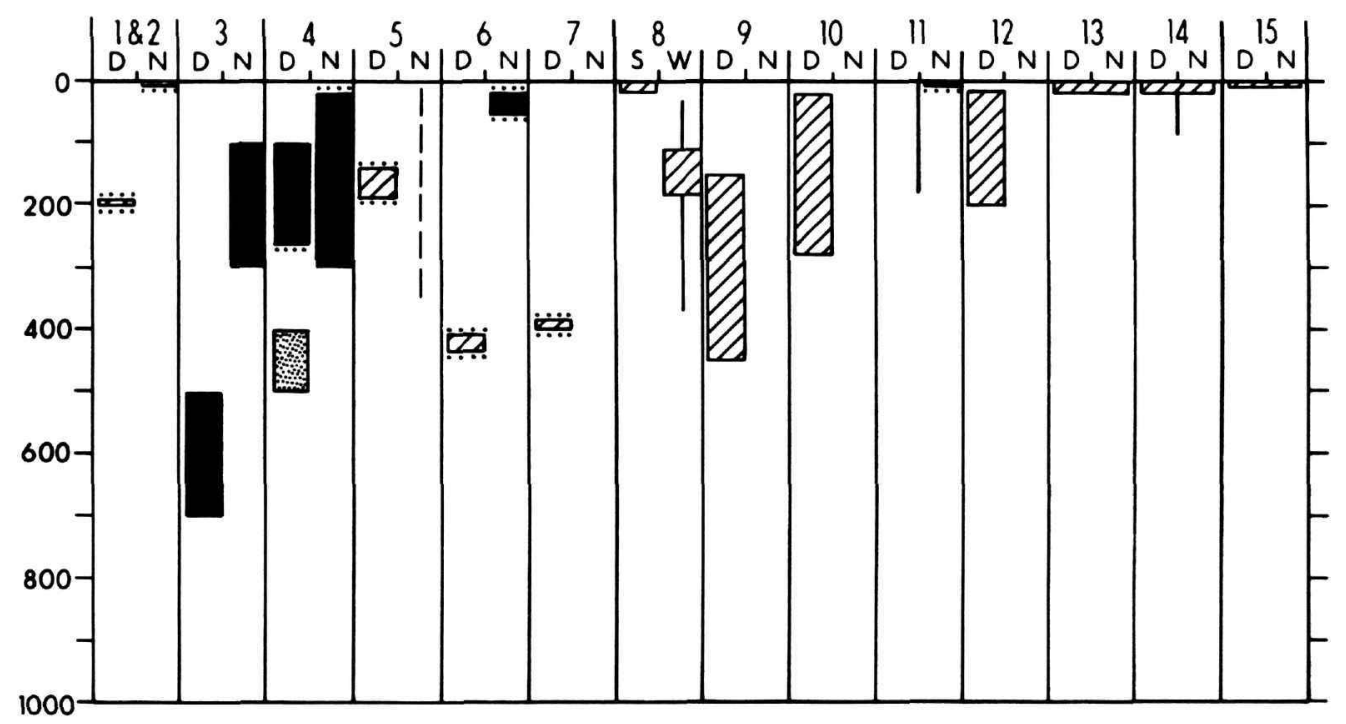

Figure 24.-Patterns of vertical migrations. 1 \& 2 NAUTILIDAE: 1, 2, Nautilus macromphalus and N. pompilius, various localities. 3 SPIRIUlidae: Spirula spirula, off Canary Islands. 4-7 HeteroTeuthinae: 4, Heteroteuthis dispar, off Canary Islands and Mediterranean; 5, Stoloteuthis leucoptera, off eastern United States (time of bottom trawl captures assumed to be day); 6, Stoloteuthis maoria, off New Zealand (time of bottom trawl captures assumed to be day); 7, Nectoteuthis pourtalesi, off Florida (time of bottom trawl captures assumed to be day). 8-14 LoliginidaE: 8, Loligo pealeii, off eastern United States; 9, Loligo forbesi, Catalane Sea (time of capture assumed to be day); 10, Loligo vulgaris, off northwest Africa; 11, Loligo plei, tropical western Atlantic; 12, Alloteuthis media, Mediterranean (time of capture assumed to be day); 13 , Sepioteuthis sepioidea, tropical western Atlantic; 14, Lolliguncula brevis, off tropical western Atlantic. 15 Pickfordiateurhidae: Pickfordiateuthis pulchella, tropical western Atlantic. (D = day, $\mathbf{N}=$ night, $\mathbf{S}=$ summer, $\mathbf{W}=$ winter; see pp. 2-3 for explanation of symbols.) 
single species, Onykia caribaea, presently qualifies as a member of the neuston, living at the ocean surface. Some other members of Onykia for which data are lacking may also occupy this habitat. Other cephalopods in this category occur primarily in the upper $50 \mathrm{~m}$ or so during the day and night. This group includes the octopods, Argonauta spp., Tremoctopus violaceus, and Ocythoe tuberculata, as well as some of the squid such as Thysanoteuthis rhombus.

Other shallow-living species avoid the nearsurface waters during the day and move into these waters during the night. These shallow diel migrators include Nautilus pompilius, N. macromphalus, Todarodes pacificus, and probably many of the loliginid species.

Among the Ommastrephidae, a number of open ocean species (e.g., $O$. caroli) seem to occur primakily in the upper few hundred meters during the day and night. Some individuals, however, apparently roam into great depths. Species that exhibit roaming activities are powerful swimmers for which data are difficult to obtain, and the extent and magnitude of roaming are uncertain.

First Order Diel Vertical Migrators.-Many species live at moderate depths during the daytime and migrate into the upper $200 \mathrm{~m}$ at night. All members of the Enoploteuthidae, where known, are first order diel vertical migrators. During the day these species occur primarily between $300 \mathrm{~m}$ and $600 \mathrm{~m}$, and at night they are found in the upper $200 \mathrm{~m}$. Within these zones, the distribution of a given species may be considerably more restricted (e.g., Pyroteuthis margaritifera). At least one member of the Lycoteuthidae, Selenoteuthis scintillans, exhibits the same pattern of distribution, and data suggest that members of the Cycloteuthidae also exhibit this pattern.

Strong diel vertical migration from great depths is indicated by data for only a single genus. Species of Brachioteuthis inhabit deep water (about 900$1000 \mathrm{~m}$ ) during the day and ascend into the upper $200 \mathrm{~m}$ at night.

Ctenopteryx sp. seems to occupy an inter-

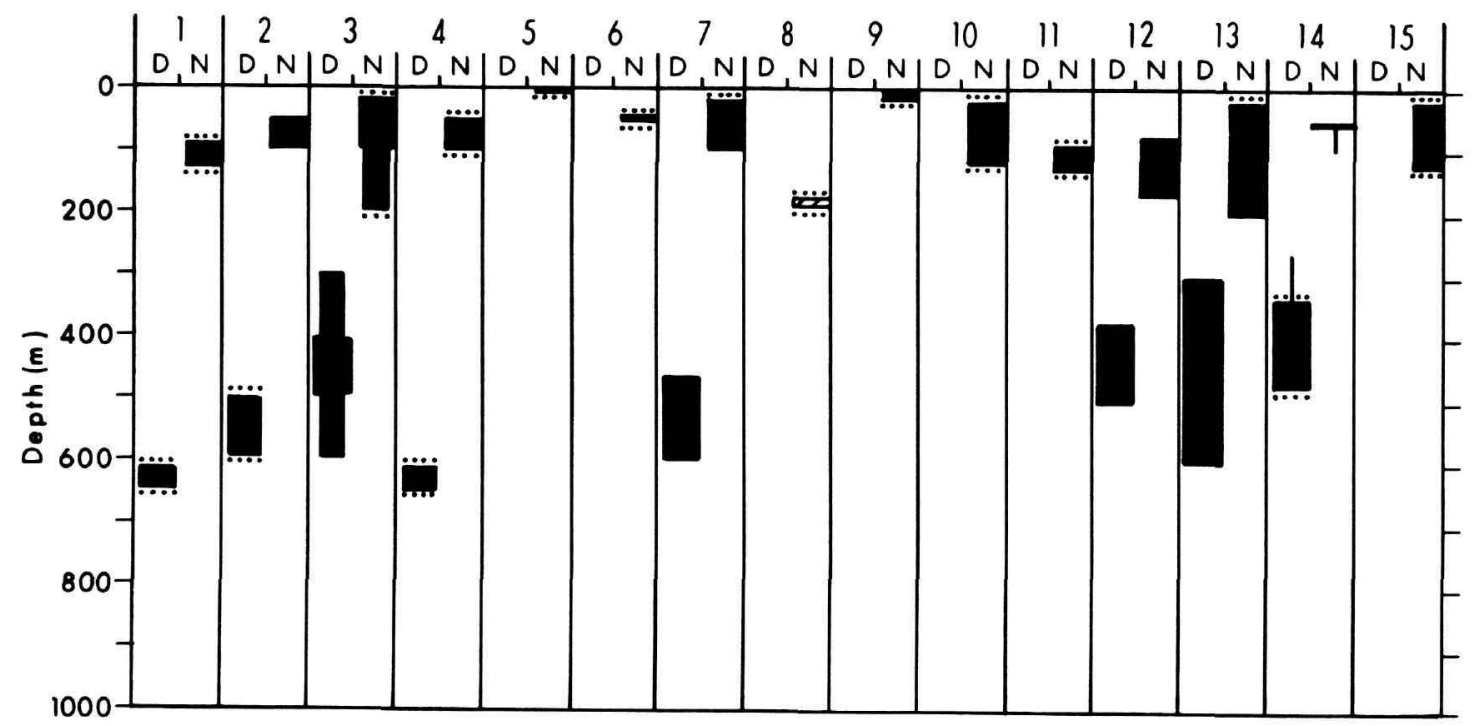

Figure 25.-Patterns of vertical migrations. 1 Lycoteuthidae: Selenoteuthis scintillans, off Bermuda. 2-15 Enoploteuthidae: 2, Abráliopsis sp., off Hawaii; 3, Abraliopsis felis, off California; 4, Abraliopsis pfefferi, off Bermuda; 5, Abralia veranyi, off Madeira; 6, Abralia redfieldi, off Bermuda; 7, Abralia trigonura, off Hawaii; 8, Abralia astrostica, off Hawaii; 9, Watasenia scintillans, off Japan; 10, Enoploteuthis anapsis, various localities; 11, Enoploteuthis sp., off Bermuda; 12, Pyroteuthis margaritifera, off Bermuda; 13, Pterygioteuthis gemmata, off Califorina; 14, Pterygioteuthis giardi, off Bermuda; 15, Thelidioteuthis alessandrinii, several localities. (D = day, $\mathbf{N}=$ night; see pp. 2-3 for explanation of symbols.) 
mediate position between the few migrators from great depths and the many from mid-depths. It migrates from $600-800 \mathrm{~m}$ into the upper $150 \mathrm{~m}$.

Second Order Diel Vertical Migrators.-At night, some species desert their daytime depths and migrate toward the surface but generally occupy deeper waters than first order migrators. For instance, Spirula spirula moves from $500-700 \mathrm{~m}$ in the day to $200-300 \mathrm{~m}$ at night, and Histioteuthis heteropsis moves from $400-800 \mathrm{~m}$ (peak at $500-700 \mathrm{~m}$ ) during the day to the upper $400 \mathrm{~m}$ at night, with a peak at $300-400 \mathrm{~m}$. Second order migrators also appear to occupy somewhat greater depths during the day than most first order migrators.

Diel Vertical Shifters.-Some species shift up- ward slightly at night with the nighttime distribution overlapping the daytime distribution. Several species of Gonatus shift from 400-800 m during the day to $300-500 \mathrm{~m}$ at night.

Diel Vertical Spreaders.-The nighttime vertical distribution in some species not only encompasses the daytime levels, but spreads well beyond the daytime limits. For example, Octopoteuthis deletron appears to occupy depths of $200-400 \mathrm{~m}$ during day and at night spreads out over depths from near the surface to about $500 \mathrm{~m}$. Although the data are insufficient, we suspect that species of Mastigoteuthis are also spreaders.

Nonmigrators.-Many species exhibit no diel changes in vertical distribution. Nonmigrators include species from near-surface waters, as men-

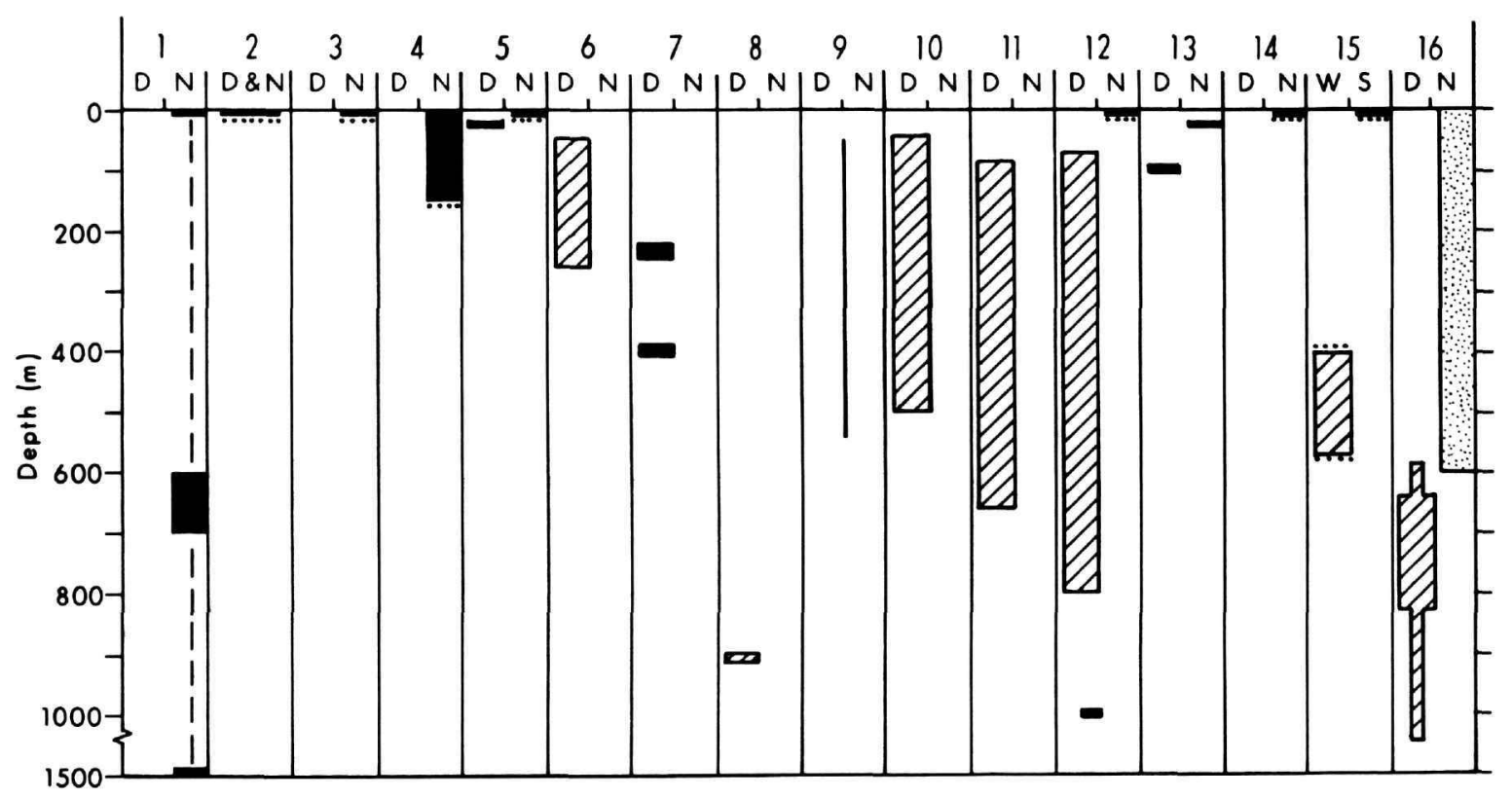

Figure 26.-Patterns of vertical migrations. 1-16 OMmAstrePhidaE: 1, Ommastrephes caroli, central Atlantic; 2, Ommastrephes bartramii, several localities and Dosidicus gigas, off western South America; 3, Symplectoteuthis oualaniensis and S. luminosa, several localities; 4, Hyaloteuthis pelagica, off Bermuda; 5, Illex illecebrosus, off Newfoundland; 6, Illex illecebrosus, off the Chesapeake Bight, eastern United States; 7, Illex illecebrosus?, off Cape Hatteras; 8, Illex sp., off Miami, Florida; 9, Illex oxygonius, western Atlantic; 10, Illex coindetii, various localities in western Atlantic and Mediterranean (time of capture assumed to be day); 11, Todaropsis eblanae, various localities (time of capture assumed to be day); 12, Todarodes sagittatus, various localities; 13, Todarodes pacificus, off Japan; 14, Nototodarus sloani gouldi, off Australia; 15, Nototodarus hawaiiensis, off Hawaii; 16, Ornithoteuthis antillarum, various localities. (D = day, $\mathrm{N}=$ night, $\mathrm{W}=$ winter, $\mathrm{S}=$ summer, $\mathrm{D} \& \mathrm{~N}=$ combined day and night captures (no marked diel differences in distribution); see pp. 2-3 for explanation of symbols.) 
tioned above, as well as species from mid-depths and from great depths. For example, Helicocranchia pfefferi occupies the same mid-depths (200-600 m) during both the day and night. Nonmigrators are more prevalent in great depths than in mid-depths. For instance, species of Bathyteuthis, Valbyteuthis, Japetella, and Vampyroteuthis infernalis are deep-living nonmigrators.
VERTICAL WANDERERS.-Individuals of some deepliving species occasionally are found during the night considerably above the normal range. This pattern is displayed by Galiteuthis phyllura which normally occurs below $900 \mathrm{~m}$, but during the night individuals may wander upward as far as the upper $100 \mathrm{~m}$.

Species Associated with the Ogean Bottom.-

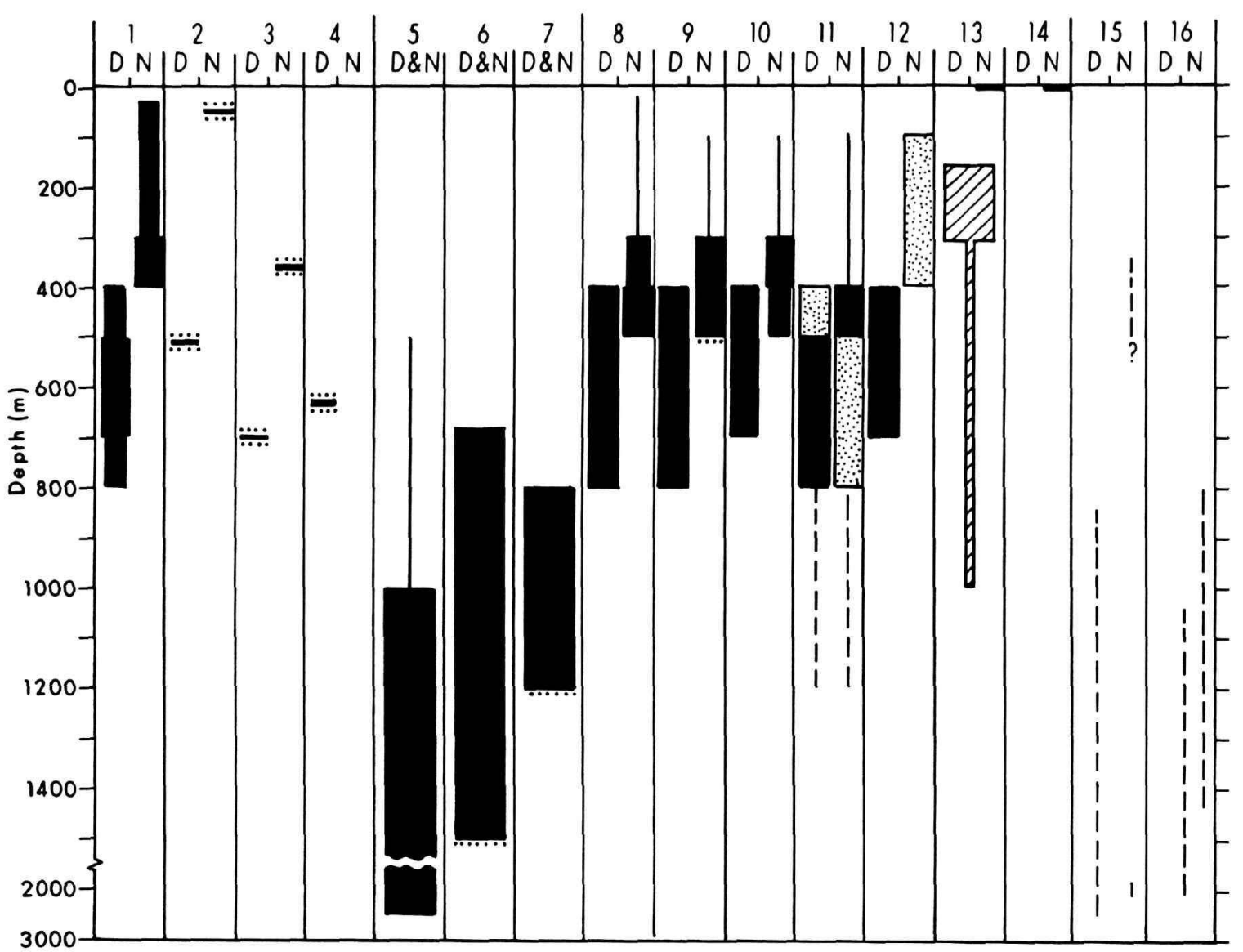

Figure 27.-Patterns of vertical migrations. 1-4 HistroteuthidaE: 1, Histioteuthis heteropsis, off California; 2, Histioteuthis dofleini, off Bermuda; 3, Histioteuthis meleagroteuthis, off Bermuda; 4, Histioteuthis corona, off Bermuda. 5-7 BathyteuthidaE: 5, Bathyteuthis abyssicola, Antarctic waters; 6, Bathyteuthis bacidifera, tropical eastern Pacific; 7, Bathyteuthis berryi, off California, 8-14 GonatidaE: 8, Gonatus onyx, off California; 9, Gonatus californiensis, off California; 10, Gonatus pyros, off California; 11, Gonatus berryi, off California; 12, Gonatopsis borealis, off California; 13, Berryteuthis magister, near Auke Bay, Alaska; 14, Berryteuthis anonychus, off Oregon. 15 JouBINITEUTHIDAE: Joubiniteuthis portieri, various localities (shallow records are assumed to be nighttime captures). 16 GrimalditeuthidaE: Grimalditeuthis bomplandii, various localities. ( $\mathrm{D}=$ day, $\mathrm{N}=$ night, $\mathrm{D} \& \mathrm{~N}=$ combined day and night captures (no marked diel differences in distribution); see pp. 2-3 for explanation of symbols.) 
A surprisingly large number of pelagic cephalopods live at least part of the time near the ocean bottom; these include shallow as well as moderately deep-living forms. Some species of the Heteroteuthinae (e.g., Stoloteuthis maoria) appear to belong to this category, as well as many species of loliginids (e.g., Loligo pealeii and $L$. vulgaris) and some ommastrephids, onychoteuthids, gonatids and mastigoteuthids.

Species Exhibiting Ontogenetic Descent.-Several species occupy progressively greater depths during successive stages in their life history. This is most apparent in species that have larvae which attain an unusually large size. For example, larval Chiroteuthis calyx with increasing size gradually descend from the upper $100 \mathrm{~m}$ to $500-700 \mathrm{~m}$ where they undergo metamorphosis at a mantle length of 50-60 mm. Many cranchiids exhibit a similar pattern (e.g., Galiteuthis phyllura, Helicocranchia pfefferi, and Phasmatopsis fisheri).

In contrast to this gradual ontogenetic descent, nearly all other species of pelagic cephalopods demonstrate a different type of ontogenetic descent; larvae occur in near surface waiers and at a particular size abruptly descend to the adult habitat. An exception to this pattern occurs in Vampyroteuthis infernalis where the young occupy greater depths than the adults.

Some of the above patterns seem to correlate approximately with familial boundaries, although many exceptions exist. Most species that live in the upper $800 \mathrm{~m}$ exhibit some type of diel change in vertical distribution. Most species that live primarily below $800 \mathrm{~m}$ do not exhibit diel variations in vertical distribution. Apparently very few species live below $1000 \mathrm{~m}$.

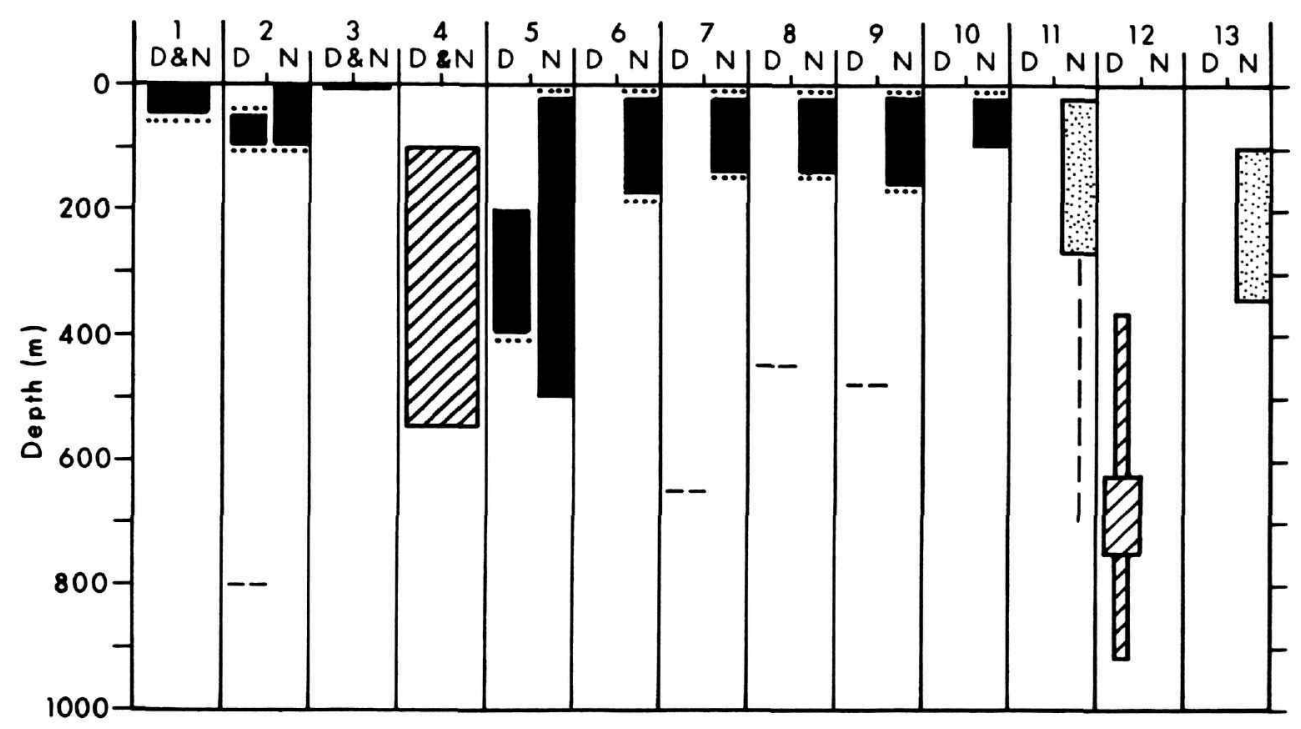

FIGURE 28.-Patterns of vertical migrations. 1. THYSANOTEUTHIDAE: Thysanoteuthis rhombus, various localities. 2-4 ONychoteUthidae: 2, Onychoteuthis banksii, off Bermuda and Mediterranean; 3, Onykia caribaea, various localities; 4, Moroteuthis robusta, off western North America. 5-6 OctopoteuthidaE: 5, Octopoteuthis deletron, off California; 6, Taningia danae, various localities. 7-9 Cycloteuthidae: 7, Cycloteuthis sirventi, various localities; 8, Discoteuthis discus, various localities; 9, Discoteuthis laciniosa, various localities. 10 Ctenopter ygidaE: Ctenopteryx spp., various localities. 11-13 LePIDOTEUTHIDAE: 11, Lepidoteuthis grimaldii, various localities; 12, Pholidoteuthis adami, Gulf of Mexico, Caribbean Sea, and northeastern South American waters; 13, Tetronychoteuthis dussumieri, various localities. $(\mathrm{D}=$ day, $\mathrm{N}=$ night, $\mathrm{D \& N}=$ combined day and night captures (no marked diel differences in distribution); see pp. 2-3 for explanation of symbols.) 


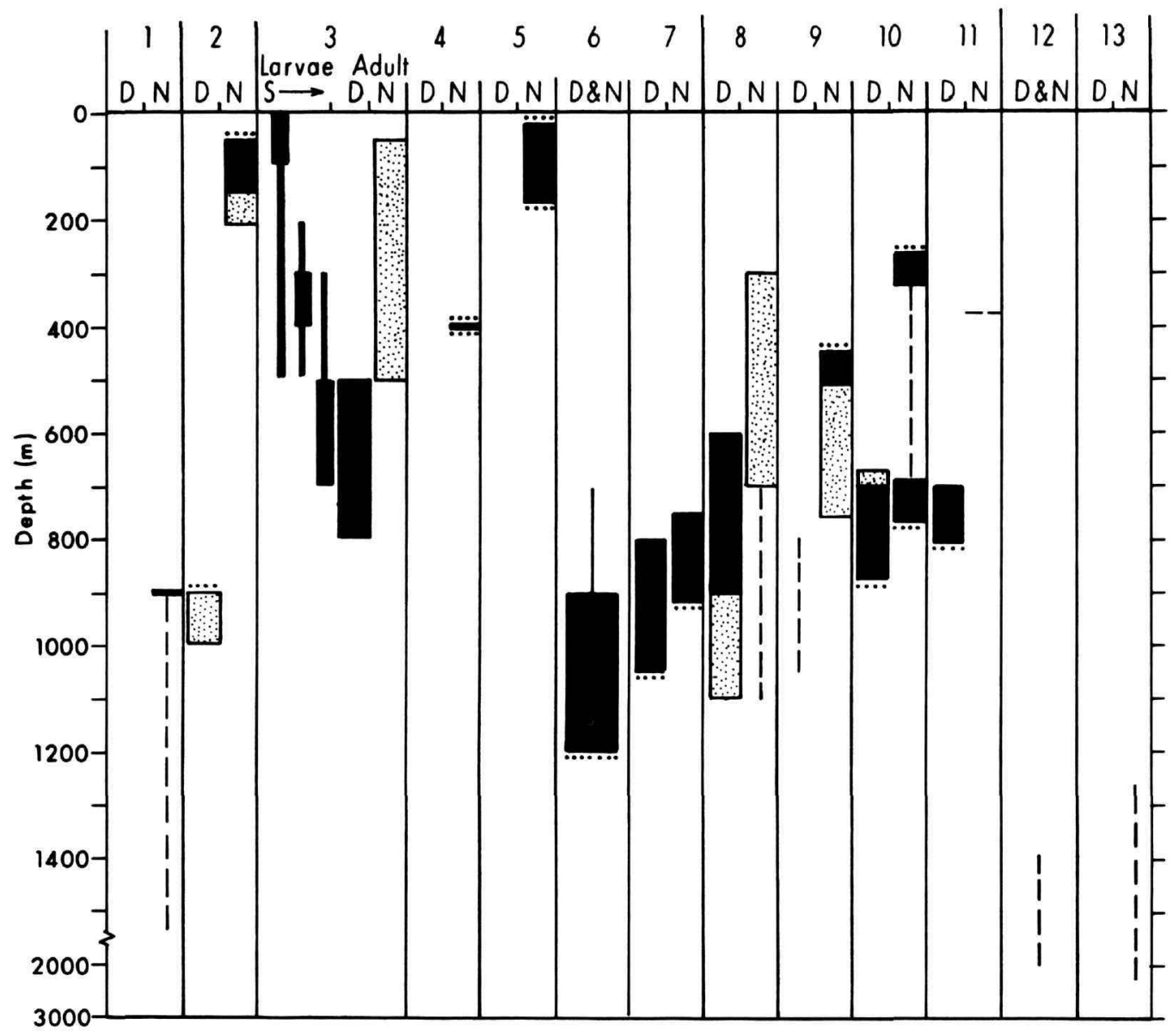

Figure 29.-Patterns of vertical migrations. 1 NeOteUthidaE: Neoteuthis sp., eastern tropical Atlantic and Gulf of Mexico. 2 BrachioteuthidaE: Brachioteuthis spp., off Hawaii and Mediterranean. 3-7 Chiroteuthidae: 3, Chiroteuthis caylx, off California; 4, Chiroteuthis veranyi, Mediterranean; 5, Chiroteuthis spp., off Hawaii and Bermuda; 6, Valbyteuthis oligobessa, off California; 7, Valbyteuthis sp., off Hawaii. 8-11 MASTIGOTEUTHIDAF: 8, Mastigoteuthis pyrodes, off Califronia; 9, Mastigoteuthis hjorti, off Bermuda; 10, Mastigoteuthis sp., off Hawaii; 11, Mastigoteuthis famelica, off Hawaii. 12 Promachoteuthidae: Promachoteuthis sp., various localities. 13 Batoteuthidae: Batoteuthis scolops, Antarctic waters. $(\mathrm{D}=$ day, $\mathrm{N}=$ night, $\mathrm{D} \& \mathrm{~N}=$ combined day and night captures (no marked diel differences in distribution), $\mathrm{S} \rightarrow=$ size of individuals increase toward the right; see pp. 2-3 for explanation of symbols.) 


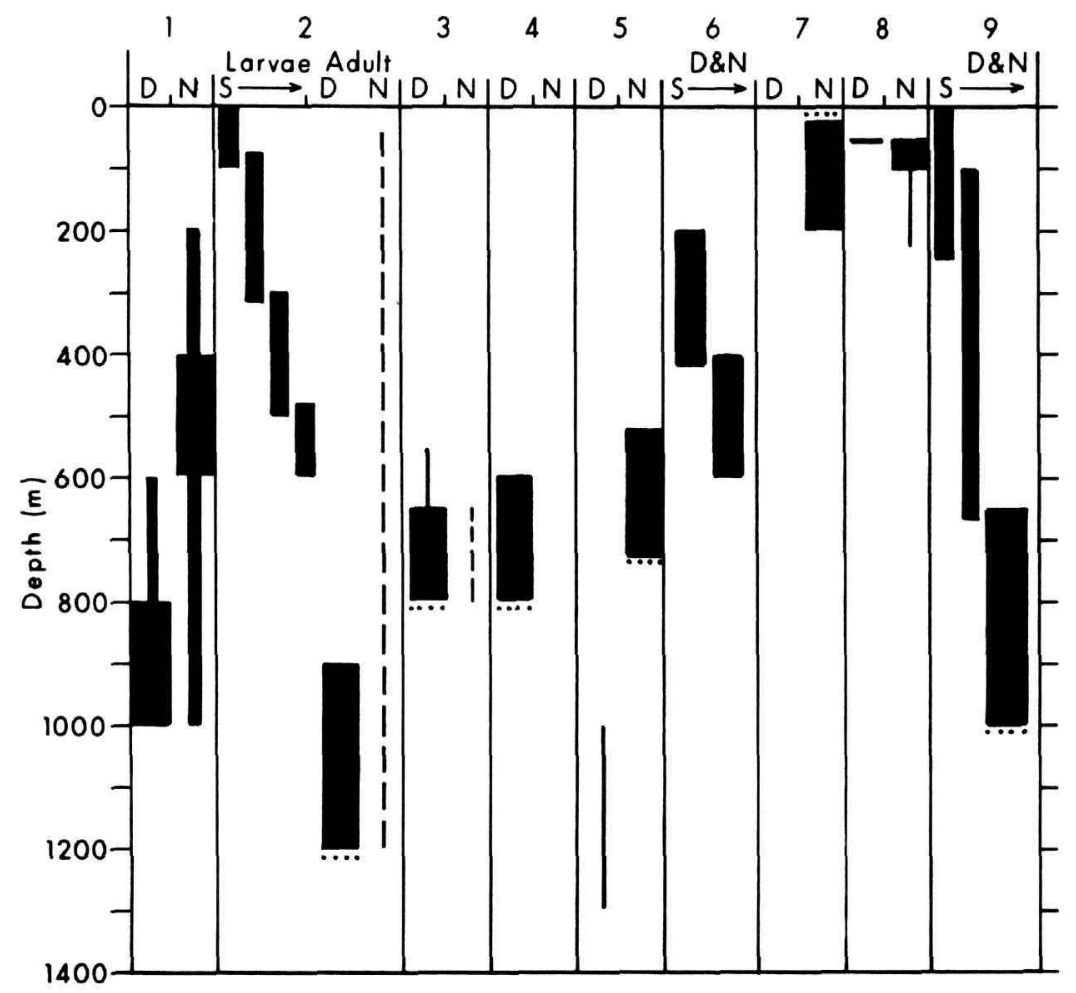

Figure 30.-Patterns of vertical migrations. 1-9 Cranchidde: 1, Galiteuthis glacialis, Antarctic waters; 2, Galiteuthis phyllura, off California; 3, Galiteuthis pacifica, off Hawaii; 4, Taonis pavo, off Bermuda and Hawaii; 5, Bathothauma lyromma, off Bermuda and Hawaii; 6, Helicocranchia pfefferi, off California; 7, Phasmatopsis fisheri, off Hawaii; 8, Leachia sp., off Bermuda; 9, Liocranchia valdiviae, off Hawaii. ( $D=$ day, $\mathbf{N}=$ night, $S \rightarrow=$ size of individuals increases to the right, $\mathrm{D \& N}=$ combined day and night captures (no marked diel differences in distribution); see pp. 2-3 for explanation of symbols.) 


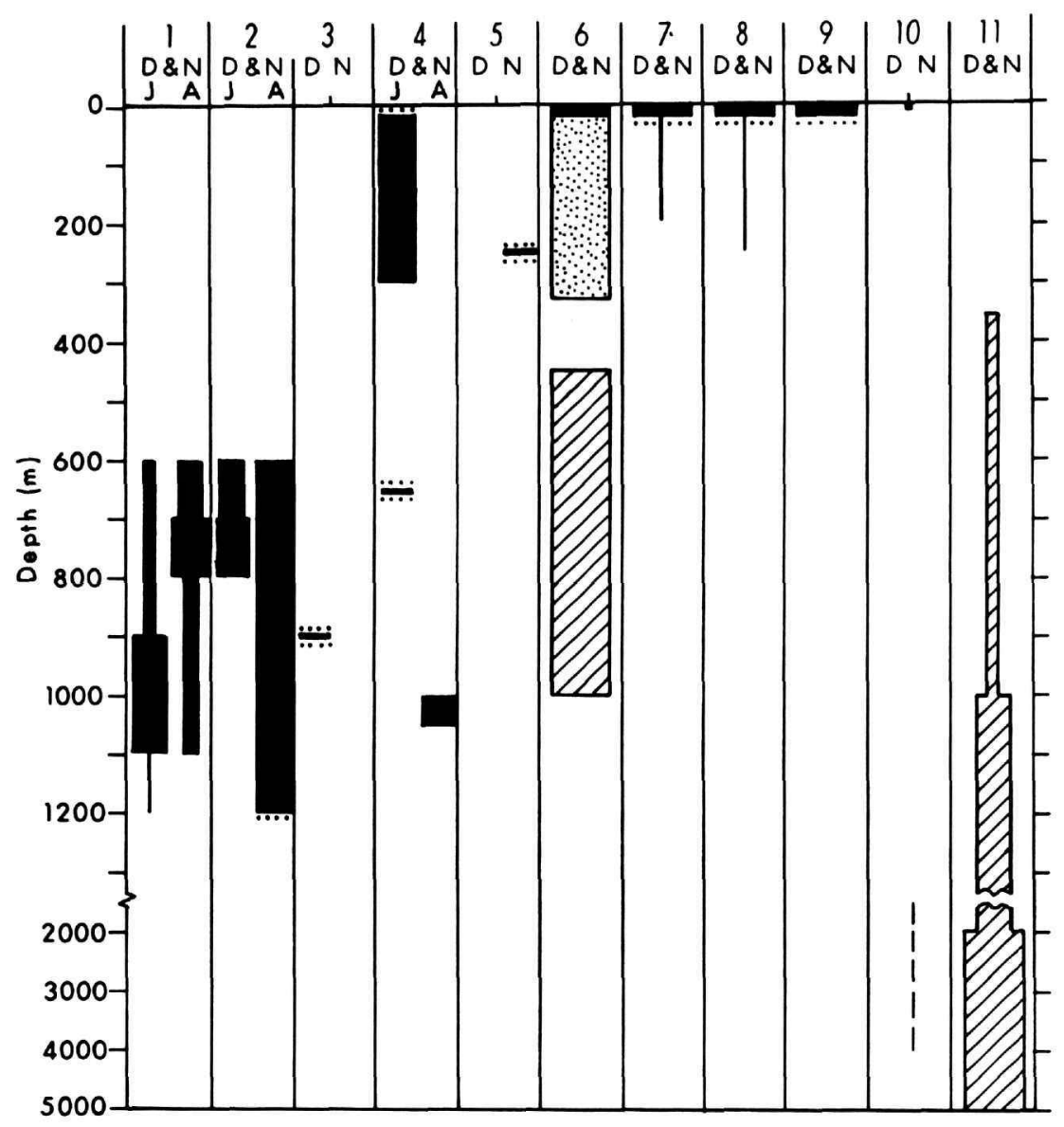

Figure 31.-Patterns of vertical migrations. I VAMPYroteuthidaE: Vampyroteuthis infernalis, off California. 2-3 Bolitaenipae: 2, Japetella sp. and J. heathi, off California; 3, Bolitaena microcotyla, off Hawaii. 4 VitrelfdoneludDAE: Vitreledonella richardi, various localities. 5 Amphitretidae: Amphitretus pelagicus, off Hawaii (consists of juveniles and larvae only). 6 Alloposidaz: Alloposus mollis, various localities. 7 Arconautidae: Argonauta spp., various localities. 8 TREMoctopodidaE: Tremoctopus violaceus, various localities. 9 OcYTHOIDAE: Ocythoe tuberculata, various localities. 10 CiRROTEUTHIDAE: Cirrothauma murrayi, various localities. 11 Cirrata: most cirrate octopods other than Cirrothauma and opisthoteuthids, various localities. (D = day, $\mathbf{N}=$ night, $\mathbf{D} \& \mathrm{~N}=$ combined day and night captures (no marked diel differences in distribution), $\mathbf{J}=$ juveniles, $\mathbf{A}=$ adults; see pp. 2-3 for explanation of symbols.) 


\section{Literature Cited}

Arata, G. F.

1954. A Note on the Flying Behavior of Certain Squids. Nautilus, 68 (1): 1-3.

Aron, W., N. Raxter, R. Noel, and W. Andrews

1964. A Description of a Discrete Depth Plankton Sampler with Some Notes on the Towing Behavior of a 6-foot Isaacs-Kidd Midwater Trawl and a Onemeter Ring Net. Limnology and Oceanography, $9(3): 324-333$.

Baker, A. De C.

1960. Observations of Squid at the Surface in the N. E. Atlantic. Deep.Sea Research, 6:206-210.

Berry, S. S.

1914. The Cephalopoda of the Hawaiian Islands. Bulletin of the Bureau of Fisheries, Washington, 32:255362.

1926. A Note on the Occurrence and Habits of a Luminous Squid (Abralia veranyi) at Madiera. Biological Bulletin, 51:257-268.

1955. On Recent Californian Occurrences of the Rare Octopod Ocythoe. California Fish and Game, 41 (2): 177-181.

Bidder, A. $\mathbf{M}$.

1962. Use of the Tentacles, Swimming and Buoyancy Control in the Pearly Nautilus. Nature, 196 (4853): 451-454.

Bruun, A. F.

1943. The Biology of Spirula spirula. Number 24 in Dana Report. 46 pages. Copenhagen.

1955. New light on the Biology of Spirula, a Mesopelagic Cephalopod. Pages 61-72 in Essays in the Natural Sciences in Honor of Captain Allen Hancock. Los Angeles: University of Southern California Press.

1957. Deep Sea and Abyssal Depths. Geological Society of America Memoir, 67 (1):641-672.

Bullen, F. T.

1899. The Cruise of the Cachalot. 271 pages. New York: Dover Publication Reprint, 1962.

Cadenat, J.

1936. Note sur un Cephalopode Geant (Architeuthis Harveyi, Verrill) capture dans le Golfe de Gascogne. Bulletin du Museum National d'Histoire Naturelle, Paris, series 2, 8:277-285.

Church, R.

1971. Deepstar Explores the Ocean Floor. National Geographic Magazine, 139:110-129.

Clarke, M. R.

1964. Young Stages of Lepidoteuthis grimaldi (Cephalopoda, Decapoda). Proceedings Malacological Society of London, 36:69-78.

1966. A Review of the Systematics and Ecology of Oceanic Squid, Advances in Marine Biology, 4:91-300.

1967. A Deep-sea Squid, Taningia danae Joubin, 1931. Symposia of the Zoological Society of London, 19: 127-143.
1969. Cephalopoda Collected on the sond Cruise. Journal of the Marine Biological Association of the United Kingdom, 49 (4):961-976.

Clarke, M. R., and N. Merrett

1972. The Significance of Squid, Whale and Other Remains from the Stomachs of Bottom-living Deep-sea Fish. Journal of the Marine Biological Association of the United Kingdom, 52 (3):599-603.

Collins, D. H., and P. Minton

1967. Siphuncular Tube of Nautilus. Nature, 216 (5118): 916-919.

Cotton, B. C.

1942. Cephalopoda from Stomach Contents of Fish from East and South Australia. Transactions of the Royal Society of South Australia, 66(1):83-84.

Degner, $\mathbf{E}$.

1925. Cephalopoda. Report on the Danish Oceanographical Expeditions 1908-1910 to the Mediterranean and Adjacent Seas, 2:1-93.

Denton, E. J., and J. B. Gilpin-Brown

1966. On the Bouyancy of Pearly Nautilus. Journal of the Marine Biological Association of the United Kingdom, 46:723-759.

1971. Further Observations on the Bouyancy of Spirula. Journal of the Marine Biological Association of the United Kingdom, 51:363-373.

Emery, K. O

1956. Deep Standing Internal Waves in California Basins. Limnology and Oceanography, 1 (1):35-41.

1960. The Sea off Southern California. 366 pages. New York: John Wiley and Sons.

Emery, K. O., and J. Hülsemann

1962. The Relationship of Sediments, Life and Water in a Marine Basin. Deep-Sea Research, 8 (3):165-180.

Fields, W. G., and V. A. Gauley

1971. Preliminary Description of an Unusual Gonatid Squid (Cephalopoda: Oegopsida) from the North Pacific. Journal of the Fisheries Research Board of Canada, 28 (11): 1796-1801.

Gibbs, R. H., Jr., and C. F. E. Roper

1970. Ocean Acre: Preliminary Report on Vertical Distribution of Fishes and Cephalopods. Pages 119133, in G. B. Farquhar, editor, Proceedings of an International Symposium on Biological Sound Scattering in the Ocean. Department of Navy, Maury Center Report 005. Washington, D.C.

Gibbs, R. H., Jr., C. F. E. Roper, D. W. Brown, and R. H. Goodyear

1971. Biological Studies of the Bermuda Ocean Acre, I: Station Data, Methods and Equipment for Cruises 1 through 11, October 1967-January 1971. 62 pages. Smithsonian Institution.

Gordon, D. C.

1970. Chemical and Biological Observations at Station Gollum, an Oceanic Station near Hawaii, January 1969 to June 1970. Hawaii Institute of Geophysics Report, 70-22:1-44. 
Hardwick, J. E.

1970. A Note on the Behavior of the Octopod Ocythöe tuberculata. California Fish and Game, 56(1):68-70.

Herring, P. J.

1967. The Pigment of Plankton at the Sea Surface. Symposia of the Zoological Society of London, 19:215235.

Holme, N. A.

1974. The Biology of Loligo forbesi Steenstrup (Mollusca: Cephalopoda) in the Plymouth area. Journal of the Marine Biological Association of the United Kingdom, 54 (2):481-503.

Kramer, G.

1937. Einige Beobachtungen an Tremoctopus violaceus Delle Chiaje. Note Instituto Biologia Marina Rovigno, 25:1-11.

LaRoe, Edward T.

1967. A Contribution to the Biology of the Loliginidae (Cephalopoda: Myopsida) of the Tropical Western Atlantic. Masters thesis, University of Miami, Coral Gables, Florida.

Lesueur, C. A.

1821. Description of Several New Species of Cuttlefish. Journal of the Academy of Natural Sciences of Philadelphia, 2 (1):86-101.

Mangold-Wirz, $\mathrm{K}$.

1963. Biologie des Céphalopodes benthiques et nectoniques de la Mer Catalane. Vie et Milieu, supplement 13:1-285.

McSweeny, E. S.

1971. Morphology and Distribution of the Antarctic Cranchiid Squid Galiteuthis glacialis (Chun). 185 pages. Ph.D. dissertation, University of Miami, Florida.

Milliman, J. D., and F. T. Manheim

1968. Observations in Deep-scattering Layers off Cape Hatteras, U.S.A. Deep-Sea Research, 15:505-507.

Moseley, H. N.

1879. Notes by a Naturalist on the Challenger. London: Macmillan and Company, 1879.

Naef, A.

1923. Die Cephalopoden: Systematik. Pages 149-863 of fascicle 2 in part 1 of volume 1 of monograph 35 in Fauna u Flora Neapel. Berlin.

Nesis, K. N.

1971a. The Squid Gonatus fabricii at the Center of the Arctic Basin. Hydrobiological Journal, 7 (1):93-96. [In Russian.]

1971b. The Family Gonatidae-Abundant Squids of the North Pacific (Their Distribution, Ecology, Systematics and Phylogeny). Pages 63-65 in Fourth Meeting of Investigation of Molluscs, Academy of Sciences, U.S.S.R. Moscow: Zoological Institute. [In Russian.]

Nishimura, $S$.

1966. Notes on the Occurrence and Biology of the Oceanic Squid, Thysanoteuthis rhombus Troschel, in Japan. Publications of the Seto Marine Biological Laboratory, $14(4)$ :327-349.
Okiyama, $\mathrm{M}$.

1969. A New Species of Gonatopsis from the Japan Sea, with the Record of a Specimen Referable to Gonatopsis sp. Okutani, 1967 (Cephalopoda: Oegopsida, Gonatidae). Publications of the Seto Marine Biological Laboratory, 17 (1):19-32.

Pattie, B. H.

1968. Notes on Giant Squid, Moroteuthis robusta (Dall) Verrill, Trawled off the Southwest Coast of Vancouver Island, Canada. Fisheries Research Papers, Washington Department of Fisheries, 3(1):47-50.

Pearcy, W.

1965. Species Composition and Distribution of Pelagic Cephalopods from the Pacific Ocean off Oregon. Pacific Science, $19(2): 261-266$.

Pearcy, W. G., and G. L. Voss

1963. A New Species of Gonatid Squid from the Northeastern Pacific. Proceedings of the Biological Society of Washington, 76:105-112.

Pereyra, W. T.

1965. New Records and Observations on the Flapjack Devilfish, Opisthoteuthis californiana Berry. Pacific Science, $19(4): 427-441$.

Pickford, G. E.

1946. Vampyroteuthis infernalis Chun, an Archaic Dibranchiate Cephalopod, I: Natural History and Distribution. Number 29 in Dana Report. 40 pages. Copenhagen.

1949. Vampyroteuthis infernalis Chun, an Archaic Dibranchiate Cephalopod, II: External Anatomy. Number 32 in Dana Report. 132 pages. Copenhagen.

Porebski, J.

1970. Observations on the Occurrence of Cephalopoda in the Waters of the N. W. African Shelf, with Particular Regard to Loligo vulgaris. Conseil International pour l'Exploration de la Mer, Rapports et Proces-Verbaux des Reunions, 159:142-145.

Rancurel, $\mathbf{P}$.

1970. Les Contenus Stomacaux d'Alepisauris ferox dans le Sue-Ouest Pacifique (Cephalopodes). Cahiers O.R.S.T.O.M., series Oceanographique, 8 (4):3-87.

Rees, W. J.

1949. Note on the Hooked Squid, Onychoteuthis banksii. Proceedings of the Malacological Society of London, 28:43-45.

Reid, J. L., Jr., G. I. Roden, and G. J. Wyllie

1958. Studies of the California Current System. Pages 2856 in Report I of California Cooperative Oceanic Fisheries Investigations. LaJolla, California.

Robson, G. C.

1932. A Monograph of the Recent Cephalopoda, Part II: The Octopoda (Excluding the Octopodinae). 359 pages. London: British Museum (Natural History).

Roper, C. F. E.

1963. Observations on Bioluminescence in Ommastrephes pteropus (Steenstrup, 1855), with Notes on its Occurrence in the Family Ommastrephidae (Mollusca: Cephalopoda). Bulletin of Marine Science of the Gulf and Caribbean, 13 (2):343-353. 
1966. A Study of the Genus Enoploteuthis (Cephalopoda: Oegopsida) in the Atlantic Ocean with a Redescription of the Type Species E. leptura (Leach, 1817). Number 66 in Dana Report. 46 pages. Copenhagen.

1969. Systematics and Zoogeography of the World-wide Bathypelagic Squid Bathyteuthis (Cephalopoda: Oegopsida). United States National Museum Bulletin, 291:1-210.

1974. Vertical and Seasonal Distribution of Pelagic Cephalopods in the Mediterranean Sea: Preliminary Report. Bulletin of the American Malacological Union, Inc., May 1974: 27-30.

Roper, C. F. E., and W. L. Brundage, Jr.

1972. Cirrate Octopods with Associated Deep-sea Organisms: New Biological Data Based on Deep Benthic Photographs (Cephalopoda). Smithsonian Contributions to Zoology, 121:1-46.

Roper, C. F. E., R. Gibbs, Jr., and W. Aron

1970. Ocean Acre: An Interim Report. 32 pages. Smithsonian Institution.

Roper, C. F. E., C. C. Lu, and K. Mangold

1969. A New Species of Illex from the Western Atlantic and Distributional Aspects of Other Illex Species (Cephalopoda: Oegopsida). Proceedings of the Biological Society of Washington, 82:295-322.

Roper, C. F. E., and R. E. Young

1967. A Review of the Valbyteuthidae and an Evaluation of its Relationship with the Chiroteuthidae (Cephalopoda: Oegopsida). Proceedings of the United States National Mumeum, 123 (3612):1-9.

1968. The Family Promachoteuthidae (Cephalopoda: Oegopsida), I: A Re-evaluation of its Systematic Position Based on New Material from Antarctic and Adjacent Waters. Antarctic Research Series, 11:203-213.

1972. First Record of Juvenile Giant Squid, Architeuthis (Cephalopoda: Oegopsida). Proceedings of the Biological Society of Washington, 85 (16):205-222.

Roper, C. F. E., R. E. Young, and G. L. Voss

1969. An Illustrated Key to the Families of the Order Teuthoidea (Cephalopoda). Smithsonian Contributions to Zoology, 13:1-32.

Sasaki, M.

1914. Observations on Hotaru-ika, Watasenia scintillans. Journal of the College of Agriculture, Tohoku Imperial University, Sapporo, 6:75-105.

1929. A Monograph of the Dibranchiate Cephalopods of the Japanese and Adjacent Waters. Journal of the College of Agriculture, Hokkaido Imperial University, supplement, 20:1-357.

Smith, A. G.

1963. More Giant Squids from California. California Fish and Game, 49:209-211.

Stenzel, H. B.

1957. Nautilus. Geological Society of America Memoir, $67(1): 1135-1141$.

Summers, W. C.

1969. Winter Population of Loligo pealei in the MidAtlantic Bight. Biological Bulletin, 137 (1):202-216.
Suzuki, T.

1963. Studies on the Relationship between Current Boundary Zones in Waters to the Southeast of Hokkaido and Migration of the Squid Ommastrephes sloani pacificus (Steenstrup). Memoirs of the Faculty of Fisheries, 11 (2):75-153.

Thore, $\mathbf{S}$.

1949. Investigations of the "Dana" Octopoda, Part I: Bolitaenidae, Amphitretidae, Vitreledonellidae and Alloposidae. Number 33 in Dana Report. 85 pages. Copenhagen.

van Hyning, J. M., and A. R. Magill

1964. Occurrence of the Giant Squid (Moroteuthis robusta) off Oregon. Research Briefs, Fish Commis. sion of Oregon, 10:67-78.

Verrill, A. E.

1882a. Report on the Cephalopods of the Northeastern Coast of America, Part I: The Gigantic Squids (Architeuthis) and their Allies; with Observations on Similar Large Species from Foreign Localities. Transactions of the Connecticut Academy of Arts and Sciences, 5:177-258.

1882b. Report on the Cephalopods of the Northeastern Coast of America, Part II: The Smaller Cephalopods, Including the "Squids" and the Octopi, with Other Allied Forms. Transactions of the Connecti. cut Academy of Arts and Sciences, 5:259-446.

Vovk, A. N.

1969. Prospects for a Squid (Loligo peali Lesueur) Fishery. Rybnoe Khozyaistvo, 10:7-9. [Translated from the Russian.]

Voss, G. L.

1956. A Review of the Cephalopods of the Gulf of Mexico. Bulletin of Marine Science Gulf and Caribbean, 6 (2):85-178.

1957. Observations on Ornithoteuthis antillarum Adam, 1957 an Ommastrephid Squid from the West Indies. Bulletin of Marine Science Gulf and Caribbean, 7 (4):370-378.

1962. A Monograph of the Cephalopoda of the North Atlantic, I: The Family Lycoteuthidae. Bulletin of Marine Science Gulf and Caribbean, 12 (2):264-305.

1967. The Biology and Bathymetric Distribution of Deepsea Cephalopods. Studies in Tropical Oceanography, 5:511-535.

Voss, N.

1969. A Monograph of the Cephalopoda of the North Atlantic: The Family Histoteuthidae. Bulletin of Marine Science, $19(4): 713-867$.

Young, R. E.

1964. A Note on Three Specimens of the Squid Lampa dioteuthis megaleia Berry, 1916 (Cephalopoda: Oegopsida) from the Atlantic Ocean, with a Description of the Male. Bulletin of Marine Science Gulf and Caribbean, 14 (3):444-452.

1972a. The Systematics and Aeral Distribution of the Cephalopods from the Seas off Southern California. Smithsonian Contributions to Zoology, 97:1-159. 
1972b. Brooding in a Bathypelagic Octopus. Pacific Science, 26 (4):400-404.

Young, R. E., and C. F. E. Roper

1968. The Batoteuthidae, a New Family of Squid (Cephalopoda: Oegopsida) from Antarctic Waters. Ant. arctic Research Series, 11:185-202. 1969a. A Monograph of the Cephalopoda of the North Atlantic: The Family Cycloteuthidae. Smithsonian Contributions to Zoology, 5:1-24.

1969b. A Monograph of the Cephalopoda of the North Atlantic: The Family Joubiniteuthidae. Smithsonian Contributions to Zoology, 15:1-10. 


\section{Index}

Abralia, 10

astrosticta, 11, 38 (fig.)

redfieldi, 10,38 (fig.)

trigonura, 11, 38 (fig.)

veranyi, 10, 38 (fig.)

Abraliopsis, 9

felis, 9, 10 (fig.), 38 (fig.)

pfefferi, 10, 38 (fig.)

sp., 10, 38 (fig.)

abyssicola, Bathyteuthis, 16 (fig.), 40 (fig.)

adami, Pholidoteuthis, 24, 41 (fig.)

Alepisaurus ferox, 16

alessandrinii, Thelidioteuthis, 12, 13, 38 (fig.)

Alloposidae, 36, 44 (fig.)

Alloposus mollis, 36, 44 (fig.)

Alloteuthis, 8

media, 8, 37 (fig.)

Alluroteuthis antarcticus, 15

Amphitretidae, 36, 44 (fig.)

Amphitretus pelagicus, 36, 44 (fig.)

anapsis, Enoploteuthis, 11, 38 (fig.)

Ancistrochirus lesueuri, 12

Ancistroteuthis lichtensteini, 22, 23

anonychus, Berryteuthis, 20, 40 (fig.)

antarcticus, Alluroteuthis, 15

antillarum, Ornithoteuthis, 13, 39 (fig.)

Architeuthidae, 16

Architeuthis, 16

argo, Argonauta, 37

Argonauta, 36, 37, 38

argo, 37

spp., 44 (fig.)

Argonautidae, 36, 37, 44 (fig.)

astrosticta, Abralia, 11, 38 (fig.)

bacidifera, Bathyteuthis, 17, 40 (fig.)

banksii, Onychoteuthis, 22, 23, 41 (fig.)

bartramii, Ommastrephes, 13, 39 (fig.)

Bathothauma, 32

lyromma, 31, 43 (fig.)

Bathyteuthidae, 16, 17, 40 (fig.)

Bathyteuthis, 40

abyssicola, 16 (fig.), 40 (fig.)

bacidifera, 17, 40 (fig.)

berryi, 17, 40 (fig.)

Batoteuthidae, 28, 42 (fig.)

Batoteuthis, 28

scolops, 42 (fig.)

berryi, Bathyteuthis, 17, 40 (fig.)

Gonatopsis, 20

Gonatus, 19, 20 (fig.), 40 (fig.)
Berryteuthis, 17

anonychus, 20, 40 (fig.)

magister, 19, 20, 40 (fig.)

Bolitaena microcotyla, 35, 44 (fig.)

Bolitaenidae, 35, 44 (fig.)

bomplandii, Grimalditeuthis, 28, 40 (fig.)

borealis, Gonatopsis, 19, 21 (fig.), 40 (fig.)

boschmai, Pholidoteuthis, 24

Brachioteuthidae, 23, 24, 42 (fig.)

Brachioteuthis, 23

sp., 23

spp., 42 (fig.)

brevis, Lolliguncula, 8,37 (fig.)

Briaster townsendii, 22

californiana, Opisthoteuthis, 34,35

californiensis, Gonatus, 17, 18 (fig.), 20, 40 (fig.)

calyx, Chiroteuthis, 24, 25 (fig.), 26 (fig.), 27, 41, 42 (fig.)

caribaea, Onykia, 22, 23, 38, 41 (fig.)

caroli, Ommastrephes, 13, 14, 38, 39 (fig.)

Centroscymnus coelolepis, 14, 16, 21, 24

Chaunoteuthis mollis, 22, 23

Chiropsis mega, 24

Chiroteuthidae, 24-27, 42 (fig.)

Chiroteuthis, 24, 27

calyx, 24, 25 (fig.), 26 (fig.), 27, 41, 42 (fig.)

sp., 26

spp., 42 (fig.)

verany, 26,42 (fig.)

Cirroteuthidae, 33, 34, 44 (fig.)

Cirroteuthis spp., 33

Cirrothauma murrayi, 34, 44 (fig.)

coelolepis, Centroscymnus, 14, 16, 21, 24

coindetii, Illex, 14, 39 (fig.)

corona, Histioteuthis, 15, 40 (fig.)

Cranchiidae, 28-32, 43 (fig.)

Ctenopterygidae, 23, 41 (fig.)

Ctenopteryx, 23

sicula, 23

spp., 41 (fig.)

Cycloteuthidae, 23, 38, 41 (fig.)

Cycloteuthis, 23

sirventi, 23, 41 (fig.)

danae, Taningia, 21, 41 (fig.)

deletron, Octopoteuthis, 21 (fig.), 39, 41 (fig.)

diadema, Lycoteuthis, 9

diaphana, Japetella, 35
Discoteuthis, 23

discus, 23, 41 (fig.)

laciniosa, 23, 41 (fig.)

discus, Discoteuthis, 23, 41 (fig.)

dislocata, Leachia, 31

dispar, Heteroteuthis, 7, 37 (fig.)

dofleini, Histioteuthis, 15, 40 (fig.)

Dosidicus gigas, 13, 39 (fig.)

dussumieri, Tetronychoteuthis, 24, 41 (fig.)

eblanae, Todaropsis, 14, 39 (fig.)

Echinoteuthis, 27

Eledonella pygmaea, 35

Enoploteuthidae, 9, 38 (fig.)

Enoploteuthis, 11

anapsis, 11, 38 (fig.)

sp., 11, 38 (fig.)

famelica, Mastigoteuthis, 28, 42 (fig.)

felis, Abraliopsis, 9, 10 (fig.), 30 (fig.)

ferox, Alepisaurus, 16

fisheri, Phasmatopsis, 32, 41, 43 (fig.)

forbesi, Loligo, 8, 37 (fig.)

Galiteuthis, 32

glacialis, 30, 43 (fig.)

pacifica, 29, 43 (fig.)

phyllura, 28, 29 (fig.), 30 (fig.), 40, 41, 43 (fig.)

gemmata, Pterygioteuthis, 12 (fig.), 38 (fig).

giardi, Pterygioteuthis, 12 (fig.), 38 (fig.)

gigas, Dosidicus, 13, 39 (fig.)

glacialis, Galiteuthis, 30, 43 (fig.)

Gonatidae, 17, 40 (fig.), 41

Gonatopsis, 17

berryi, 20

borealis, 19, 21 (fig.), 40 (fig.)

Gonatus, 17, 19, 39

berryi, 19, 20 (fig.), 40 (fig.)

californiensis, 17, 18 (fig.) 20, 40 (fig.)

onyx, 17 (fig.), 20, 40 (fig.)

pyros, 18, 19 (fig.), 20, 40 (fig.)

grimaldii, Lepidoteuthis, 24,41 (fig.)

Grimalditeuthidae, 28, 40 (fig.)

Grimalditeuthis bomplandii, 28, 40 (fig.)

Grimpoteuthis, 33

hawaiiensis, Heteroteuthis, 8

Nototodarus, 14, 39 (fig.) 
heathi, Japetella, 35 (fig.), 44 (fig.)

Helicocranchia, 32

pfefferi, 30, 31 (fig.), 40, 41, 43 (fig.)

heteropsis, Histioteuthis, 14, 15 (fig.), 39, 40 (fig.)

Heteroteuthis, 7,8

dispar, 7, 37 (fig.)

hawaiiensis, 8

Histioteuthidae, 14, 15, 40 (fig.)

Histioteuthis, 14

corona, 15, 40 (fig.)

dofleini, 15, 40 (fig.)

heteropsis, 14, 15 (fig.), 39, 40 (fig.)

meleagroteuthis, 15, 40 (fig.)

hjorti, Mastigoteuthis, 27, 42 (fig.)

Hyaloteuthis pelagica, 13, 39 (fig.)

Idiosepiidae, 7, 8

illecebrosus, Illex, 13, 14, 39 (fig.)

Illex, 14

coindetii, 14, 39 (fig.)

illecebrosus, 13, 14, 39 (fig.)

oxygonius, 14,39 (fig.)

sp., 39 (fig.)

infernalis, Vampyroteuthis, 32, 33 (fig.), 40, 41, 44 (fig.)

Japetella, 40

diaphana, 35

heathi, 35 (fig.), 44 (fig.)

sp., 35 (fig.), 44 (fig.)

Joubiniteuthidae, 24, 40 (fig.)

Joubiniteuthis portieri, 24, 40 (fig.)

laciniosa, Discoteuthis, 23, 41 (fig.)

Lampadioteuthis megaleia, 9

Leachia, 32

dislocata, 31

sp., 31, 43 (fig.)

Lepidoteuthidae, 24, 41 (fig.)

Lepidoteuthis grimaldii, 24, 41 (fig.)

lesueuri, Ancistroteuthis, 12

leucoptera, Stoloteuthis, 7, 37 (fig.)

lichtensteini, Ancistroteuthis, 22, 23

Liocranchia valdiviae, 32,43 (fig.)

Loliginidae, 8, 37 (fig.)

Loligo, 8

forbesi, 8, 37 (fig.)

pealeii, 8,37 (fig.), 41

plei, 8,37 (fig.)

vulgaris, 8,37 (fig.), 41

Lolliguncula, 8

brevis, 8, 37 (fig.)

lucifer, Tremoctopus, 36

luminosa, Symplectoteuthis, 13, 39 (fig.)

Lycoteuthidae, 9, 38 (fig.)

Lycoteuthis diadema, 9

lyromma, Bathothauma, 31, 43 (fig.) macromphalus, Nautilus, 6, 37 (fig.), 38 magister, Berryteuthis, 19, 20, 40 (fig.)

margaritifera, Pyroteuthis, 11 (fig.), 12, 13, 38 (fig.)

maoria, Stoloteuthis, 7, 37 (fig.), 41

Mastigoteuthidae, 27, 28, 41, 42 (fig.)

Mastigoteuthis, 27, 39

famelica, 28, 42 (fig.)

hjorti, 27, 42 (fig.)

pyrodes, 27 (fig.), 42 (fig.)

sp., 27, 42 (fig.)

media, Alloteuthis, 8, 37 (fig.)

mega, Chiropsis, 24

megaleia, Lampadioteuthis, 9

megaptera, Promachoteuthis, 28

meleagroteuthis, Histioteuthis, 15, 40 (fig.)

microcotyla, Bolitaena, 35, 44 (fig.)

mollis, Alloposus, 36, 44 (fig.)

Chaunoteuthis, 22, 23

Moroteuthis robusta, 22, 23, 41 (fig.)

murrayi, Cirrothauma, 34, 44 (fig.)

Nautilidae, 6, 37 (fig.)

Nautilus, 6

macromphalus, 6, 37 (fig.), 38 pompilius, 6,37 (fig.), 38

Nectoteuthis pourtalesi, 8,37 (fig.)

Neoteuthidae, 15, 16, 42 (fig.)

Neoteuthis, 15

thielei, 15

sp., 15, 42 (fig.)

Nototodarus, 14

hawaiiensis, 14, 39 (fig.)

sloani gouldi, 14, 39 (fig.)

oceanica, Phasmatopsis, 32

Octopodteuthidae, 21, 22, 41 (fig.)

Octopoteuthis, 21

deletron, 21 (fig.) 39, 41 (fig.)

Ocythoe tuberculata, 36, 38, 44 (fig.)

Ocythoidae, 36, 44 (fig.)

oligobessa, Valbyteuthis, 26 (fig.) 42 (fig.)

Ommastrephes, 13

bartramii, 13, 39 (fig.)

caroli, 13, 14, 38, 39 (fig.)

pteropus, 13

Ommastrephidae, 13, 14, 38, 39 (fig.), 41

Onychoteuthidae, 22, 23, 41 (fig.)

Onychoteuthis, 22

banksii, 22, 23, 41 (fig.)

Onykia, 38

caribaea, 22, 23, 38, 41 (fig.)

onyx, Gonatus, 17 (fig.), 20, 40, (fig.)

Opisthoteuthidae, 34, 35

Opisthoteuthis californiana, 34, 35

Oregoniateuthis spingeri, 9

Ornithoteuthis, 13 antillarum, 13, 39 (fig.)

volitilis, 13

oualaniensis, Symplectoteuthis, 13, 39 (fig.)

oxygonius, Illex., 14, 39 (fig.)

pacifica, Galiteuthis, 29, 43 (fig.)

pacificus, Todarodes, 14, 38, 39 (fig.)

pavo, Taonius, 31,43 (fig.)

pealeii, Loligo, 8, 37 (fig.) 41

pelagica, Hyaloteuthis, 13, 39 (fig.)

pelagicus, Amphitretus, 36, 44 (fig.)

pfefferi, Abraliopsis, 10, 38 (fig.)

Helicocranchia, 30, 31 (fig.), 40, 41, 43

$$
\text { (fig). }
$$

Phasmatopsis, 32

fisheri, 32, 41, 43 (fig.)

oceanica, 32

Pholidoteuthis, 24

adami, 24, 41 (fig.)

boschmai, 24

phyllura, Galiteuthis, 28, 29 (fig.), 30 (fig.), 40, 41, 43 (fig.)

Pickfordiateuthidae, 9, 37 (fig.)

Pickfordiateuthis, 9 pulchella, 9, 37 (fig.)

plei, Loligo, 8, 37 (fig.)

pompilius, Nautilus, 6, 37 (fig.), 38

portieri, Joubiniteuthis, 24, 40 (fig.)

pourtalesi, Nectoteuthis, 8,37 (fig.)

Promachoteuthidae, 28, 42 (fig.)

Promachoteuthis, 28

megaptera, 28

sp., 42 (fig.)

Psychroteuthidae, 15

Psychroteuthis, 15

pteropus, Ommastrephes, 13

Pterygioteuthis, 11, 12

gemmata, 12 (fig.), 38 (fig.)

giardi, 12 (fig.), 38 (fig.)

pulchella, Pickfordiateuthis, 9, 37 (fig.)

pygmaea, Eledonella, 35

pyrodes, Mastigoteuthis, 27 (fig.), 42 (fig.)

pyros, Gonatus, 18, 19 (fig.), 20, 40 (fig.)

Pyroteuthis, 11

margaritifera, 11 (fig.), 12, 13, 38 (fig.)

redfieldi, Abralia, 10, 38 (fig.)

rhombus, Thysanoteuthis, 23, 38, 41 (fig.)

richardi, Vitreledonella, 35, 44 (fig.)

robusta, Moroteuthis, 22, 23, 41 (fig.)

sagittatus, Todarodes, 14, 39 (fig.)

Sargassum, 22

scintillans, Selenoteuthis, 9, 38 (fig.)

Watasenia, 1, 11, 38 (fig.)

scolops, Batoteuthis, 42 (fig.)

Sclenoteuthis, 9 
scintillans, 9, 38 (fig.)

Sepiadariidae, 7, 8

Sepiidae, 7

sepioidea, Sepioteuthis, 8, 37 (fig.)

Sepiolidae, 7,8

Sepioteuthis sepioidea, 8, 37 (fig.)

sicula, Ctenopteryx, 23

sirventi, Cycloteuthis, 23, 41 (fig.)

sloani gouldi, Nototodarus, 14, 39 (fig.)

Spirula spirula, 6, 7, 37 (fig.), 39

spirula, Spirula, 6, 7, 37 (fig.), 39

Spirulidae, 6, 7, 37 (fig.)

springeri, Oregoniateuthis, 9

Stauroteuthis, 33

Stoloteuthis, 7

leucoptera, 7, 37 (fig.)

maoria, 7, 37 (fig.), 41

Symplectoteuthis, 13

luminosa, 13, 39 (fig.)

oualaniensis, 13, 39 (fig.)
Taningia, 21

danae, 21, 41 (fig.)

Taonius, 32

pavo, 31, 43 (fig.)

Tetronychoteuthis dussumieri, 24, 41 (fig.)

Thelidioteuthis alessandrinii, 12, 13, 38 (fig.)

thielei, Neoteuthis, 15

Thysanoteuthidae, 23, 41 (fig.)

Thysanoteuthis rhombus, 23, 38, 41 (fig.)

Todarodes, 14

pacificus, 14, 38, 39 (fig.)

sagittatus, 14, 39 (fig.)

Todaropsis eblanae, 14, 39 (fig.)

townsendii, Briaster, 22

Tremoctopodiae, 36, 44 (fig.)

Tremoctopus, 36

lucifer, 36

violaceus, 36, 38, 44 (fig.) trigonura, Abralia, 11, 38 (fig.)

tuberculata, Ocythoe, 36, 38, 44 (fig.)

Valbyteuthis, 24, 27, 40

oligobessa, 26 (fig.), 42 (fig.)

sp., 42 (fig.)

valdiviae, Liocranchia, 32, 43 (fig.)

Vampyroteuthidae, 32, 33, 44 (fig.)

Vampyroteuthis infernalis, 32, 33 (fig.),

$40,41,44$ (fig.)

veranyi, Abralia, 10, 38 (fig.)

Chiroteuthis, 26, 42 (fig.)

violaceus, Tremoctopus, 36, 38, 44 (fig.)

Vitreledonella richardi, 35, 44 (fig.)

Vitreledonellidae, 35, 36, 44 (fig.)

volitilis, Ornithoteuthis, 13

vulgaris, Loligo, 8, 37 (fig.), 41

Watasenia scintillans, 1, 11, 38 (fig.) 



\section{Publication in Smithsonian Contributions to Zoology}

Manuscripts for serial publications are accepted by the Smithsonian Institution Press, subject to substantive review, only through departments of the various Smithsonian museums. NonSmithsonian authors should address inquiries to the appropriate department. If submission is invited, the following format requirements of the Press will govern the preparation of copy.

Copy must be typewritten, double-spaced, on one side of standard white bond paper, with 11/2." top and left margins, submitted in ribbon copy with a carbon or duplicate, and accompanied by the original artwork. Duplicate copies of all material, including illustrations, should be retained by the author. There may be several paragraphs to a page, but each page should begin with a new paragraph. Number consecutively all pages, including title page, abstract, text, literature cited, legends, and tables. The minimum length is 30 pages, including typescript and illustrations.

The title should be complete and clear for easy indexing by abstracting services. Taxonomic titles will carry a final line indicating the higher categories to which the taxon is referable: "(Hymenoptera: Sphecidae)." Include an abstract as an introductory part of the text. Identify the author on the first page of text with an unnumbered footnote that includes his professional mailing address. A table of contents is optional. An index, if required, may be supplied by the author when he returns page proof.

Two headings are used: (1) text heads (boldface in print) for major sections and chapters and (2) paragraph sideheads (caps and small caps in print) for subdivisions. Further headings may be worked out with the editor.

In taxonomic keys, number only the first item of each couplet; if there is only one couplet, omit the number. For easy reference, number also the taxa and their corresponding headings throughout the text; do not incorporate page references in the key.

In synonymy, use the short form (taxon, author, date:page) with a full reference at the end of the paper under "Literature Cited." Begin each taxon at the left margin with subsequent lines indented about three spaces. Within an entry, use a period-dash (.-) to separate each reference. Enclose with square brackets any annotation in, or at the end of, the entry. For references within the text, use the author-date system: "(Jones, 1910)" and "Jones (1910)." If the reference is expanded, abbreviate the data: "Jones (1910:122, pl. 20: fig. 1)."

Simple tabulations in the text (e.g., columns of data) may carry headings or not, but they should not contain rules. Formal tables must be submitted as pages separate from the text, and each table, no matter how large, should be pasted up as a single sheet of copy.

Use the metric system instead of, or in addition to, the English system.

Illustrations (line drawings, maps, photographs, shaded drawings) can be intermixed throughout the printed text. They will be termed Figures and should be numbered consecutively; however, if a group of figures is treated as a single figure, the components should be indicated by lowercase italic letters on the illustration, in the legend, and in text references: "Figure $9 b$." If illustrations (usually tone photographs) are printed separately from the text as full pages on a different stock of paper, they will be termed Plates, and individual components should be lettered (Plate $9 b$ ) but may be numbered (Plate 9: figure 2). Never combine the numbering system of text illustrations with that of plate illustrations. Submit all legends on pages separate from the text and not attached to the artwork. An instruction booklet for the preparation of illustrations is available from the Press on request.

In the bibliography (usually called "Literature Cited"), spell out book, journal, and article titles, using initial caps with all words except minor terms such as "and, of, the." For capitalization of titles in foreign languages, follow the national practice of each language. Underscore (for italics) book and journal titles. Use the colon-parentheses system for volume, number, and page citations: "10(2):5-9." Spell out such words as "figures," "plates," "pages."

For free copies of his own paper, a Smithsonian author should indicate his requirements on "Form 36" (submitted to the Press with the manuscript). A non-Smithsonian author will receive 50 free copies; order forms for quantities above this amount with instructions for payment will be supplied when page proof is forwarded. 


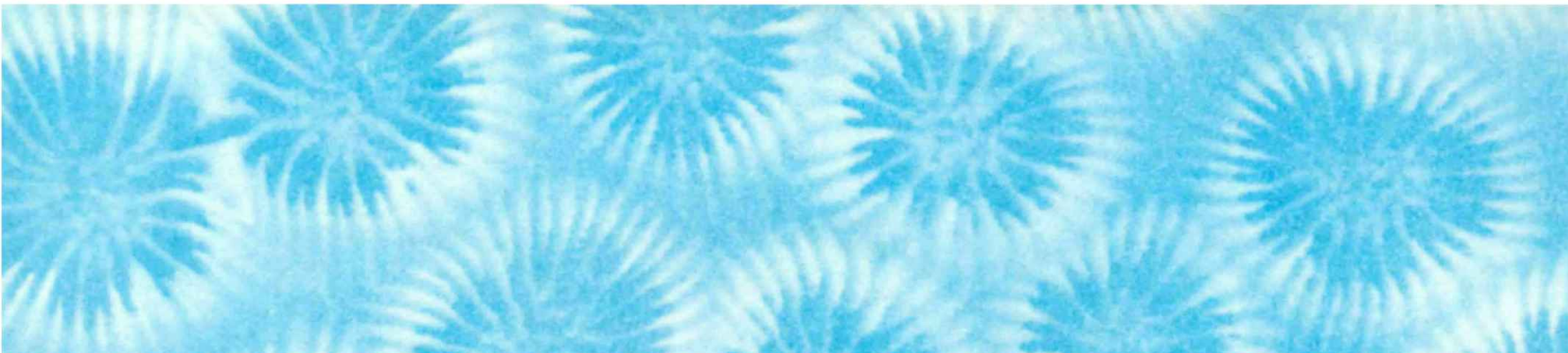

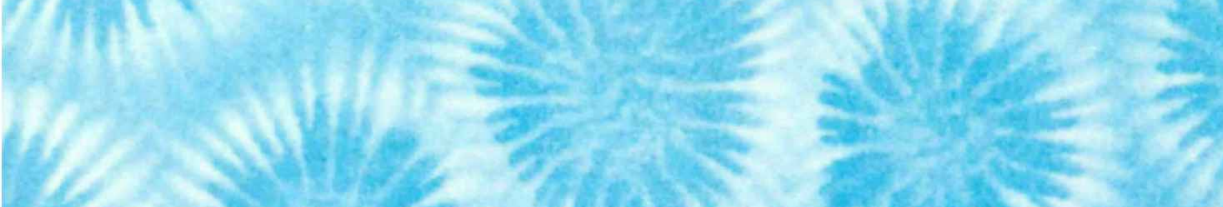

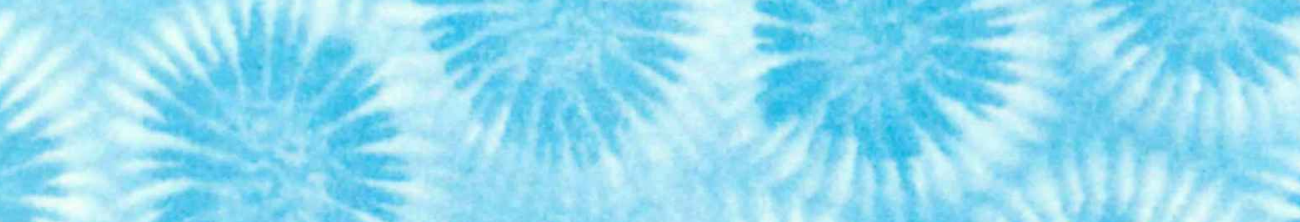

S Ohing

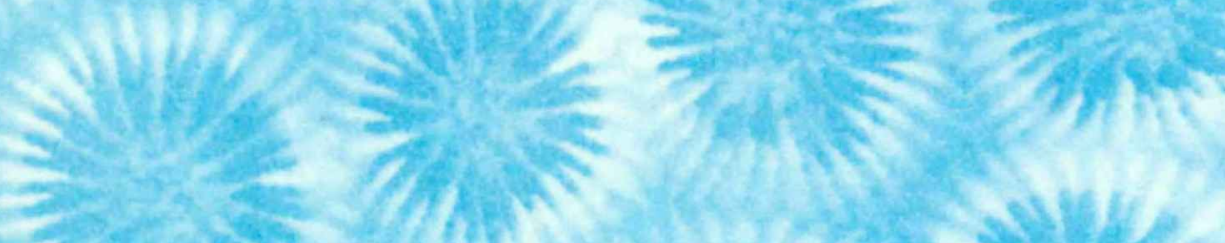

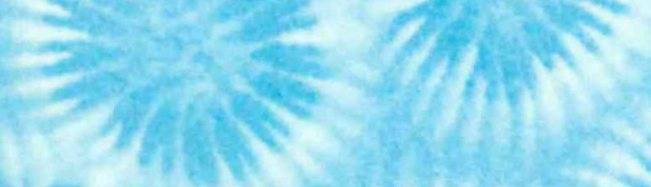

Sut

\section{(c)}

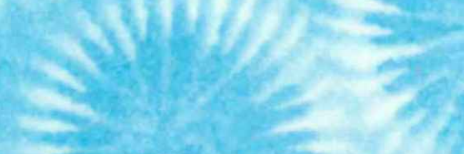

MW $\frac{3}{3}$ min

Nive 3) (b) $=\frac{1}{3}$ (Hily 4

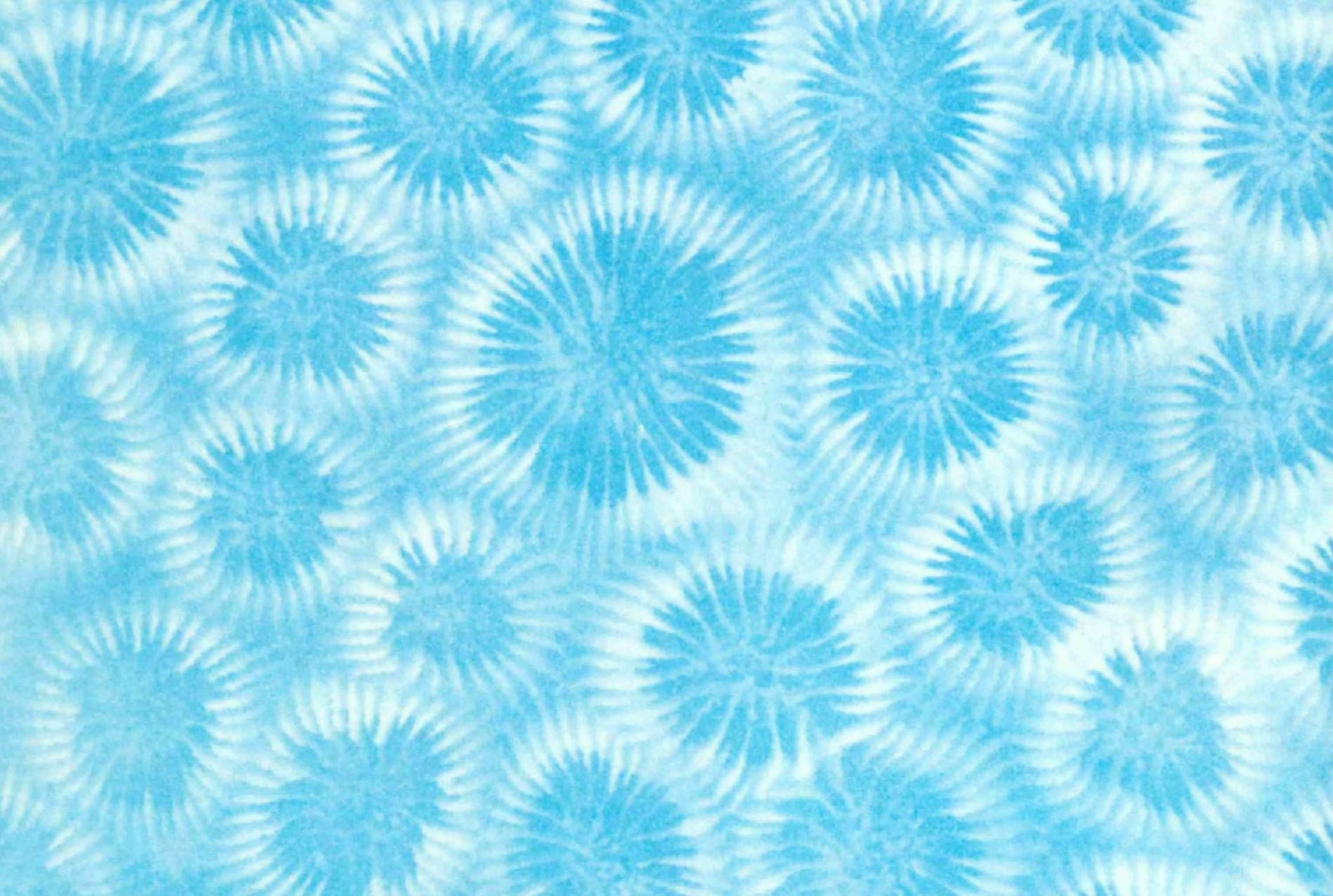

ghe Nawe nille

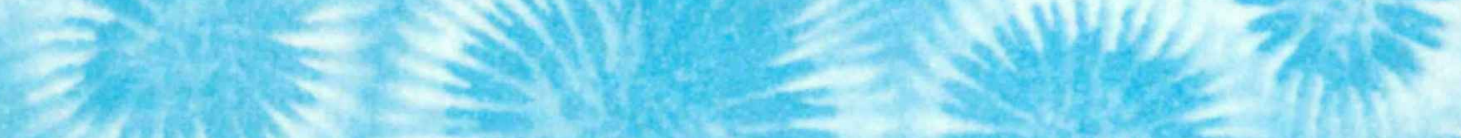

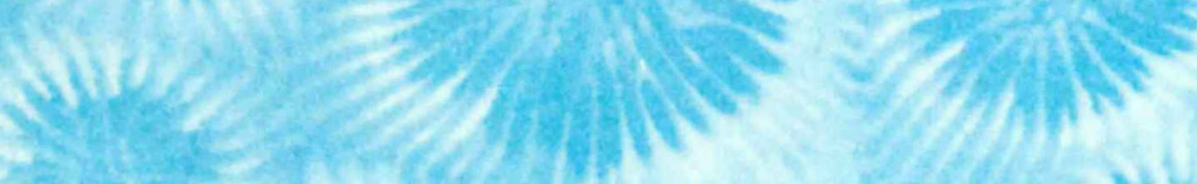

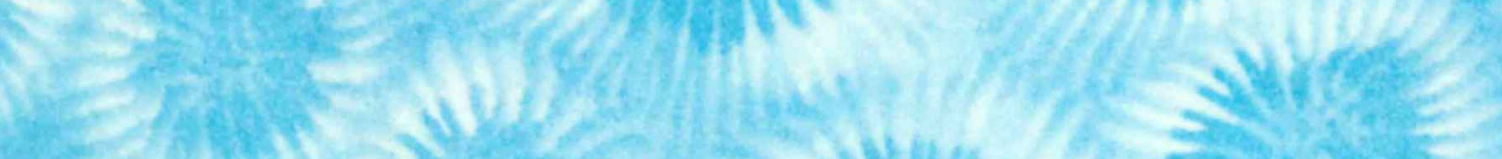

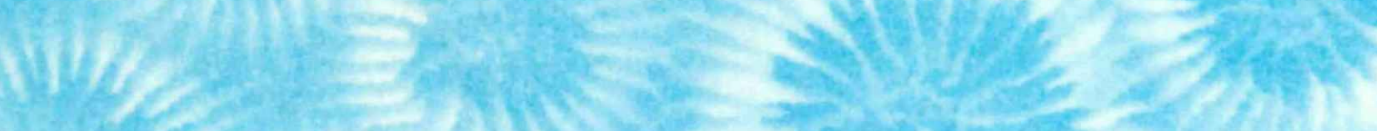

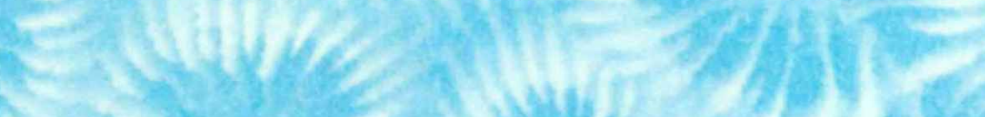

